\title{
BIODEGRADAÇÃO E ADSORÇÃO DOS HERBICIDAS DIURON E AMETRINA EM SOLOS TRATADOS COM VINHAÇÄ
}

\section{FÁBIO PRATA}

Engenheiro Agrônomo

Orientador: Prof. Dr. ARQUIMEDES LAVORENTI

Dissẹrtação apresentada à Escola Superior de Agricultura "Luiz de Queiroz", Universidade de São Paulo, para obtenção do título de Mestre em Agronomia, Área de Concentração: Solos e Nutrição de Plantas.

PIRACICABA

Estado de São Paulo - Brasil

Dezembro - 1998 
Dados Internacionais de Catalogação na Publicação (CIP) DIVISÃo DE BIBLIOTECA E DOCUMENTAÇÃO - Campus "Luiz de Queiroz"/USP

Prata, Fábio

Biodegradação e adsorsāo dos herbicidas diuron e ametrina em solos tratados com vinhaça / Fábio Prata. - - Piracicaba, 1998.

$73 \mathrm{p}$.

Dissertação (mestrado) - - Escola Superior de Agricultura Luiz de Queiroz, 1998. Bibliografia.

1. Adsorção 2. Biodegradação 3. Herbicida 4. Microbiologia do solo 5. Planta daninha 6. Química do solo 7. Vinhaça l. Título

CDD 631.41 


\section{AGRADECIMENTOS}

Agradeço a todos que de alguma forma contribuíram com este trabalho e, em especial:

Ao Prof. Dr. Arquimedes Lavorenti, pela orientação, estímulo, exemplo, respeito e amizade;

A Dra. Jussara Borges Regitano e ao Dr. Valdemar Luis Tornisielo, pelos ensinamentos, colaboração e estímulo em todas as etapas deste trabalho;

À laboratorista Rosângela Aparecida De Gaspari Rocha, pelo auxílio na realização das análises;

Aos amigos Tadeu Cavalcante Reis e Adriana Marlene Moreno Pires, pela verdadeira amizade construída e, a todos os colegas do CPG em Solos e Nutrição de Plantas;

Ao Prof. Dr. Arthur Santos Filho, pelo encaminhamento científico;

Aos Profs. Dr. Márcio Lambais e Dr. Raymond Pacovsky pelas sugestões;

Àos Profs. Dr. Godofredo César Vitti, Dr. Eurípedes Malavolta, Dr. Murilo de Melo, Dr. Luís Reynaldo F. Alleoni, Dr. Otávio Antônio Camargo, Dr. Quirino A. C. Carmello, Dra. Maria Cristina Stolf Nogueira, Dra. Elke J. B. Cardoso, Dr. Adolpho José Melfi e Dr. José Carlos Chitolina, pelos conhecimentos transmitidos durante o curso;

À Coordenadoria de Aperfeiçoamento de Pessoal de Nível Superior - CAPES, pelo suporte financeiro; 
À BIOAGRI (Biotecnologia Agrícola), pela colaboração;

Ao Departamento de Química da Escola Superior de Agricultura "Luiz de Queiroz" e a Seção de Ecotoxicologia do Centro de Energia Nuclear na Agricultura pela estrutura e materiais cedidos e por tornar possivel a realização deste trabalho;

À Lilian, Dona Lídia, Dona Nadir e aos meus verdadeiros amigos, pelo apoio nas horas necessárias. 
aos meus pais,

Nadir Corrêa Prata e Nelson Prata "in memorian", OFEREÇO

Ao mais novo Prata, Guga,

DEDICO 


\section{SUMÁRIO}

Página

RESUMO

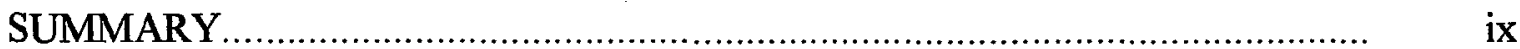

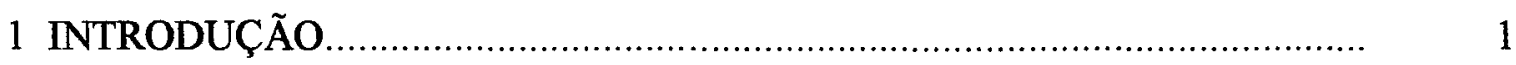

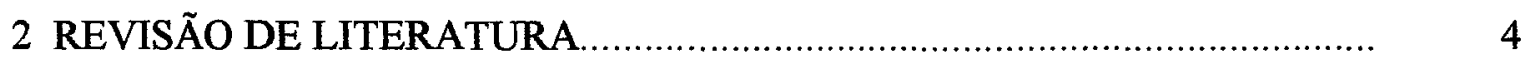

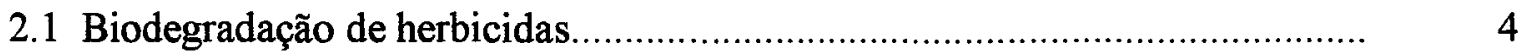

2.2 Adsorção de herbicidas............................................................................ 8

2.3 Efeito da vinhaça nas propriedades químicas e biológicas do solo................. 11

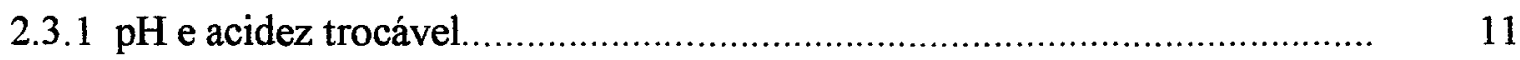

2.3.2 Carbono orgânico e bases trocáveis.......................................................... 12

2.3.3 Propriedades biológicas.......................................................................... 14

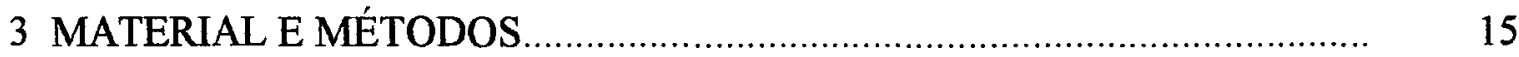

3.1 Local de investigação.............................................................................. 15

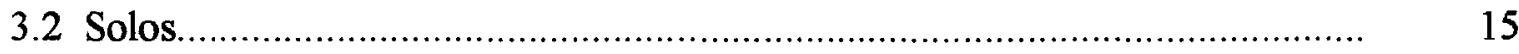

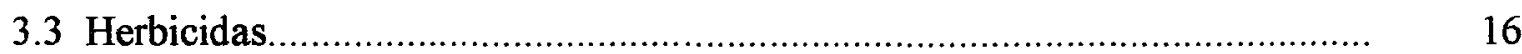

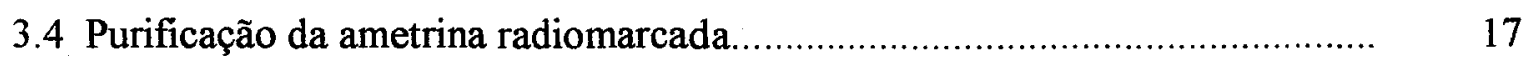

3.5 Preparo da solução do herbicida.................................................................. 17

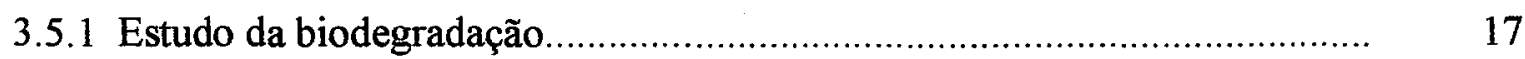

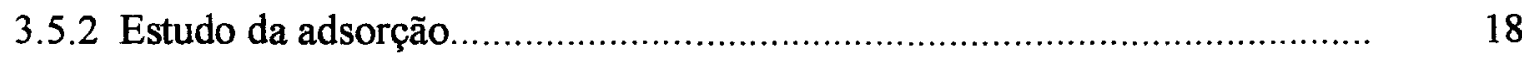

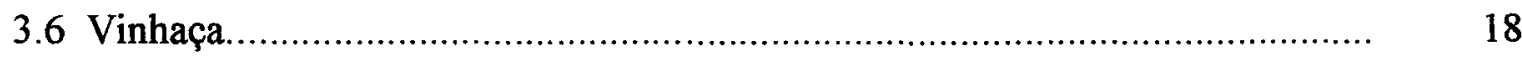

3.7 Quantidade de vinhaça aplicada............................................................... 19

3.8 Pré-incubação do solo com a vinhaça ............................................................ 19

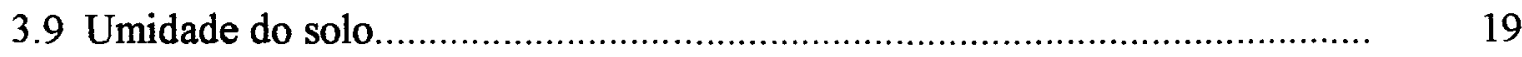

3.10 Procedimento para o estudo da biodegradação.............................................. 19

3.10.1 Determinação do ${ }^{14} \mathrm{CO}_{2}$ despreendido.................................................. 21

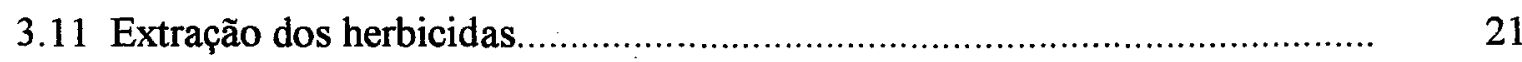

3.12 Cromatografia de camada delgada (TLC)................................................ 22 
3.13 Atividade microbina

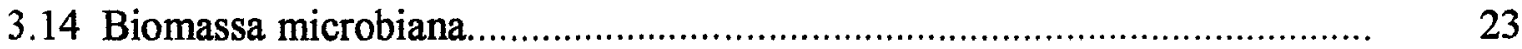

3.15 Procedimento para o estudo da adsorção................................................... 23

3.16 Cálculo da quantidade do herbicida adsorvida ............................................. 24

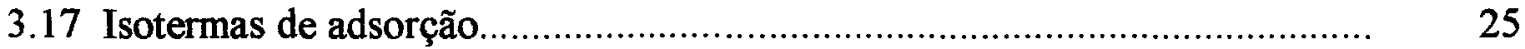

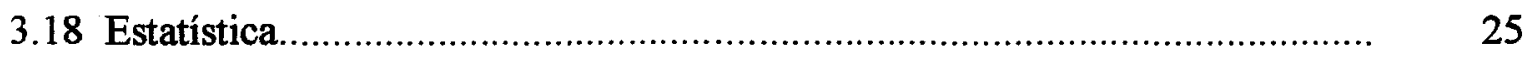

4 RESULTADOS E DISCUSSÃO............................................................. 26

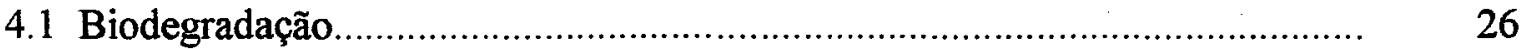

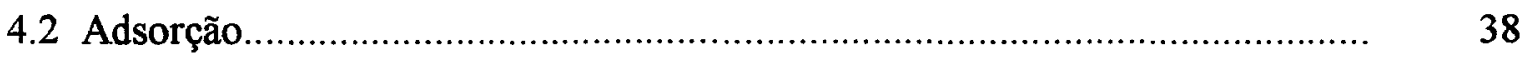

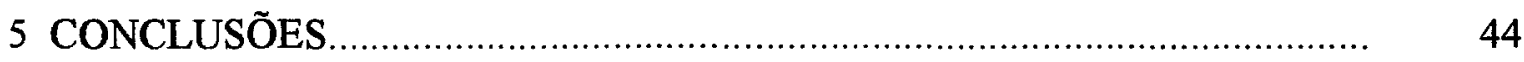

REFERÊNCIAS BIBLIOGRÁFICAS.............................................................. 45

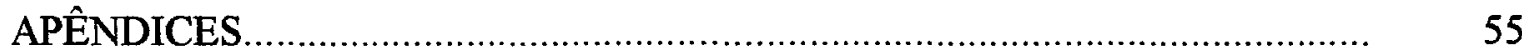




\title{
BIODEGRADAÇÃO E ADSORÇÃO DOS HERBICIDAS DIURON E AMETRINA EM SOLOS TRATADOS COM VINHAÇA
}

\author{
Autor: FÁBIO PRATA \\ Orientador: Prof. Dr. ARQUIMEDES LAVORENTI
}

\section{RESUMO}

Diuron e ametrina são herbicidas muito empregados no controle de plantas daninhas na cultura da cana-de-açúcar no Brasil, cultura a qual representa grande área cultivada no Estado de São Paulo. Dentre as práticas de manejo mais utilizadas nesta cultura, atualmente, podemos citar a adição de vinhaça como prática rotineira em soqueiras de cana e, sabe-se hoje, que a vinhaça atua sobre propriedades químicas e biológicas do solo que podem interferir no comportamento dos pesticidas neste ambiente. Desta forma, este estudo tem como objetivo avaliar os efeitos da adição de vinhaça, nas doses de 100 e $200 \mathrm{~m}^{3} \mathrm{ha}^{-1}$, nos processos de biodegradação e adsorção de diuron e ametrina em solos das classes Terra Roxa Estruturada (TR) e Latossolo Vermelho Amarelo (LV).

Para o estudo da biodegradação foram instalados dois experimentos, sob condições controladas de laboratório, com a capacidade máxima de retenção de água no solo mantida a $60 \%$ e temperatura a $25^{\circ} \mathrm{C} \pm 2^{\circ} \mathrm{C}$, em delineamento inteiramente casualizado arranjado em fatorial 2 (solos) x 3 (vinhaça:0, 100 e $200 \mathrm{~m}^{3} \mathrm{ha}^{-1}$ ), sendo um experimento para o diuron e outro para a ametrina. A aplicação dos herbicidas foi feita 4 dias após a adição da vinhaça e o experimento foi conduzido por 120 dias, 
sendo as avaliações procedidas semanalmente até 63 dias após a aplicação e a última somente aos 120 dias. A biodegradação foi avaliada por radiorespirometria e a deteç̧ão do ${ }^{14} \mathrm{CO}_{2}$ despreendido foi feita por cintilação líquida. Após os 120 dias, as moléculas dos herbicidas e seus metabólitos foram extraídas do solo por agitação e centrifugação, utilizando-se o metanol como solvente. A detecção foi feita em "radio-scanner".

Paralelo a este estudo, foi feito um experimento em arranjo fatorial $2 \times 2 \times 3$ (solos, herbicidas, doses de vinhaça), no qual avaliou-se o efeito das doses de vinhaça, com os herbicidas, na atividade microbiana, $\mathrm{pH}$ e carbono orgânico do solo até 63 dias após a aplicação, para efeito de possíveis explicações para os resultados obtidos no primeiro estudo. Foram feitas determinações da biomassa microbiana no início e final do experimento.

Os experimentos de adsorção foram realizados nas mesmas condições empregadas na biodegradação. Utilizou-se uma relação solo:solvente de 1:10 e as concentrações utilizadas foram de 1,$37 ; 2,67 ; 5,0 ; 7,0$ e $10,0 \mu \mathrm{gL}^{-1}$ para o diuron e 2,$47 ; 5,0 ; 7,5 ; 10,0$ e $12,5 \mu \mathrm{g} \mathrm{mL}^{-1}$ para a ametrina. A deteç̧ão das moléculas radiomarcadas nas soluções de equilíbrio foi feita por cintilação líquida.

Os resultados obtidos mostraram que a biodegradação do diuron foi maior com o aumento das doses de vinhaça no solo TR, sendo constante no LV. Para a ametrina constatou-se uma maior biodegradação, nos dois solos, quando adicionado $100 \mathrm{~m}^{3} \mathrm{ha}^{-1}$ do resíduo em comparação com as outras doses que não se diferenciaram. A biodegradação, na maioria dos casos, acompanhou as variações da atividade e biomassa microbiana com a adição da vinhaça. Diferentes metabólitos foram detectados na degradação do diuron, variando com as doses de vinhaça. $\mathrm{O}$ mesmo não foi observado para a ametrina, que não produziu metabólitos. Tanto a adsorção do diuron quanto da ametrina foi maior no solo TR que no $L V$, não apresentando influencia da adição da vinhaça. 


\title{
BIODEGRADATION AND SORPTION OF DIURON AND AMETRYNE HERBICIDES IN SOILS AMENDED WITH VINASSE.
}

\author{
Author: FÁBIO PRATA \\ Adviser: Prof. Dr. ARQUIMEDES LAVORENTI
}

\section{SUMMARY}

Diuron and ametryne herbicides are largely used in Brazil to control weeds on sugarcane, a crop grown widely in São Paulo State. Vinasse (sugarcane residue from the alcoholic fermentation) is greatly used during and following the second year of sugarcane cultivation and subsequently years of sugarcane cultivation and this product has interfered with some chemical and biological properties of the soil. This effect might interfere with the behavior of the applied pesticides. The aim of this study was to evaluate the effects of vinasse (100 and $200 \mathrm{~m}^{3} \mathrm{ha}^{-1}$ ) on the biodegradation and sorption of diuron and ametryne herbicides in Rhodudalf and Haplorthox soils.

Two trials for the degradation study were carried out under laboratory conditions, with the water holding capacity and the temperature of the soils maintained at $60 \%$ and $25^{\circ} \mathrm{C} \pm 2^{\circ} \mathrm{C}$, respectively. A completely randomized design was used with a factorial experiment of 2 (soils) $\times 3$ (vinasse: 0,100 and $200 \mathrm{~m}^{3} \mathrm{ha}^{-1}$ ) for the diuron and ametryne were carried out. Herbicide was applied to the soils 4 days after the vinasse application and then this mixture was incubated for 120 days with weekly evaluations made up to 63 days and with a final evaluation at 120 days. 
Biodegradation was evaluated by radiorespirometry with the ${ }^{14} \mathrm{CO}_{2}$ evolution measured by liquid scintillation. At the end of the incubation, the original compounds and their metabolites were extracted from the soils with methanol on both trials by shaking followed by centrifuge and the detection of residue radioactivity with the radioscanner.

In parallel to this study, another experiment was carried out using a factorial design of $2 \times 2 \times 3$ ( soils, herbicides, vinasse doses) in order to evaluate the effect of the vinasse doses and herbicides on the microbial activity, $\mathrm{pH}$ and organic carbon content of the soil during the 63 days of incubation. We also wished to get more information that might explain the results obtained in the degradation study. Microbial biomass was evaluated at the beginning and at the end of the experiment.

The sorption experiment was carried out under the same conditions as the biodegradation study. A soil:solvent ratio of 1:10 and five doses of diuron: 1.37, 2.67, $5.0,7.0$ and $10.0 \mu \mathrm{g} \mathrm{mL}^{-1}$ and five doses of ametryne: $2.47,5.0,7.5,10.0$ and $12.5 \mu \mathrm{g}$ $\mathrm{mL}^{-1}$ were used. The radioactivity was measured by liquid scintillation.

Our results indicate that the diuron biodegradation in the Rhodudalf soil increased with the increasing doses of vinasse, but on the Haplorthox soil there was no difference. For the ametryne the highest biodegradation was observed with $100 \mathrm{~m}^{3} \mathrm{ha}^{-1}$ vinasse on both soils. The biodegradation resulting from vinasse addition followed the observed variation in microbial activity and microbial biomass. Depending on the vinasse doses, different metabolites of diuron were observed at the end of the experiment by thin-layer chromatography (TLC) but, for the ametryne, no metabolites were observed. The diuron and ametryne sorption study showed that the vinasse did not affect any sorption process in either soils and that the sorption on the Rhodudalf soil was higher than the Haplorthox soil. 


\section{INTRODUCC̃̃o}

Quando Lineu procurou classificar toda a vida, em 1758, deu a seu grandioso trabalho o título de Systema Naturae (Sistema da natureza). Estudiosos de todas as gerações subseqüentes inundaram a literatura científica com sistemas alternativos igualmente abrangentes. Seu conteúdo diferiu, mas permaneceu a paixão pela elaboração de sistemas. A ânsia de dar sentido a complexibilidade que nos cerca, de reunir tudo, sempre superou nossa cautela ante essa formidável tarefa.

Neste sentido, a literatura mostra que muito antes da compreensão dos mecanismos envolvidos no controle das plantas invasoras de cultivo, o homem já utilizava-se de produtos químicos para tal atividade. $\mathrm{O}$ início do uso destes produtos químicos datam do começo deste século, sendo eles basicamente sais como os cloretos e boratos. Entretanto, a história é pródiga em nos dizer sobre um dos castigos impostos a Tiradentes, que teve suas terras esterilizadas com sal como parte do castigo infligido aos inconfidentes, mostrando já no século passado o uso de um produto químico como herbicida.

$\mathrm{Na}$ década de 1940 foram sintetizados os primeiros herbicidas orgânicos, incluindo-se entre eles o 2,4-D e MCPA, fato que representou um avanço extraordinário no controle de plantas daninhas. Estes compostos, estudados inicialmente como reguladores de crescimento, mostraram-se excelentes herbicidas no controle de espécies dicotiledôneas em cereais, e ainda, além de serem seletivos, agiam com quantidades muito pequenas por área. 
A partir daí o avanço no uso de produtos químicos no controle de plantas daninhas foi grande e muito rápido, de tal maneira que atualmente estão registrados no Instituto Brasileiro do Meio Ambiente (IBAMA) cerca de 250 ingredientes ativos, colocando o Brasil entre os 5 maiores consumidores de pesticidas no mundo, o qual apresenta um mercado estimado em 27 milhões de dólares (Monteiro, 1998).) Dos xenobióticos utilizados como pesticidas, $65 \%$ são herbicidas, $25 \%$ são inseticidas e $7 \%$ são fungicidas. Os $3 \%$ restantes incluem os nematicidas, acaricidas, rodenticidas, moluscicidas e outros (Fay et al., 1998).

Com o crescente uso destas moléculas orgânicas nas últimas décadas, vem surgindo também a preocupação com o seu comportamento no ambiente, isto é, se a molécula pode ser um poluidor ambiental em potencial, pois com sucessivas aplicações destes produtos químicos, especula-se que nas próximas décadas possa explodir o chamado "Chemical Time Bomb" ou efeito da bomba relógio, que seria um extremo da poluição ambiental.

Inúmeros estudos com várias moléculas já foram desenvolvidos em muitos sentidos. Entretanto, muitos fenômenos ainda não estão bem esclarecidos, como por exemplo a degradação de pesticidas em diferentes ambientes numa escala de tempo, a formação de metabólitos que possam ser tóxicos às plantas, animais ou ao homem, os mecanismos de sorção de muitas moléculas com os colóides do solo etc..

A degradação de um herbicida, forma importante de destoxificação do produto no ambiente, juntamente com a adsorção, que é responsável pela retenção do herbicida à superficie do solo, são processos influenciados pela estrutura química da molécula, granulometria do solo, tipo de argila, $\mathrm{pH}$, temperatura do solo, umidade do solo, presença de outros íons na solução do solo, formulação usada, concentração dos produtos adicionados e aplicações prévias, e teor e qualidade de matéria orgânica do solo.

Dentre as principais culturas agrícolas cultivadas no Brasil, a cana-de-açúcar apresenta-se como uma das que mais utilizam herbicidas no controle das plantas invasoras, destacando-se, entre outras, as moléculas do grupo químico dos derivados da uréia e triazinas. 
Em 1975, com a criação do PROÁLCOOL, o álcool que até então era um subproduto do açúcar, passou a ser o produto direto da cana-de-açúcar e, com isto, a quantidade de resíduo, vinhaça, que era aproximadamente de $150 \mathrm{~L} \mathrm{t}^{-1}$ de cana processada passou a $900 \mathrm{~L} \mathrm{t}^{-1}$. As áreas com esta cultura também aumentaram e, dessa forma, a quantidade das sobras do resíduo que antes não constituía tão grande problema em termos de poluição ambiental, já que era um subproduto de um subproduto do açúcar - o álcool, e as quantidades deste resíduo eram relativamente pequenas, sua eliminação era feita em cursos de água localizados nas proximidades das usinas. Todavia, a partir de 1975 a produção de vinhaça elevou-se em tamanha proporção que já não poderia mais ser lançada nos rios em função do pronunciado aumento da demanda bioquímica de oxigênio (DBO), o qual seria extremamente nocivo à biota dos rios (Camargo et al., 1984).

Levando-se ainda em conta o grande aumento no custo dos fertilizantes minerais na época, a aplicação da vinhaça ao solo e seus estudos como fonte alternativa de nutrientes pode ser vista como uma conseqüência necessária.

Hoje, a aplicação de vinhaça como fonte de nutrientes, principalmente para a cultura da cana-de-açúcar, tem-se mostrado uma eficaz alternativa de adubação potássica e pode ser considerada como prática rotineira nas soqueiras dessa cultura. Por outro lado, a vinhaça, além de ser uma fonte de potássio para a cana, atua em várias características químicas, físicas e biológicas do solo as quais poderiam interferir nos processos de biodegradação e adsorção de herbicidas no solo.

Dentro deste contexto, este trabalho tem como objetivo estudar a influência desse resíduo orgânico nos processos de biodegradação e adsorção dos herbicidas diuron e ametrina nos solos Terra Roxa Estruturada textura muito argilosa e Latossolo Vermelho Amarelo textura média-arenosa.

Espera-se com esta pesquisa, que a biodegradação dos herbicidas seja maior com a adição da vinhaça e que a adsorção das moléculas não seja interferida pelo resíduo. 


\section{REVISÃO DE LITERATURA}

\subsection{Biodegradação de herbicidas}

A maioria das moléculas de herbicidas é transformada pela ação do metabolismo de microorganismos, assim, o termo biodegradação tipicamente refere-se a transformação microbiológica de um composto químico orgânico para outra forma, sem referir-se a extensão (Monteiro, 1996). Entretanto, Bollag \& Liu (1990) explicam que a degradação microbiana pode acontecer por reações metabólicas diretas, consideradas primárias, ou por efeitos indiretos dos microorganismos em características físicas e químicas do ambiente, resultando em transformações secundárias. Segundo esses mesmos autores, cinco são os processos envolvidos nas transformações microbianas de pesticidas no solo:

- Biodegradação; o pesticida serve como fonte de energia para o crescimento e desenvolvimento dos microorganismos degradadores.

- Cometabolismo; o pesticida é transformado por reações metabólicas mas não serve como fonte de energia para o microorganismo, não levando, geralmente, a uma completa degradação da molécula.

- Polimerização ou conjugação; a molécula integral do xenobiótico ou um de seus metabólitos se combina com compostos naturais do solo como aminoácidos ou carboidratos, ou outra molécula pesticida. A formação do conjugado normalmente torna a molécula mais polar e assim mais hidrolisável.

- Acúmulo; a molécula do pesticida é incorporada ao microorganismo sem que seja degradada. $\mathrm{O}$ acúmulo de moléculas pesticidas por microorganismos 
pode ocorrer por processo ativo ou passivo e traz uma grande preocupação, uma vez que esta interferência microbiana significa apenas a remoção temporária da molécula tóxica.

- Efeitos secundários da atividade microbiana; o pesticida é transformado em decorrência de alterações no $\mathrm{pH}$, potencial redox etc., promovidas pela atividade microbiana.

A biodegradação ocorre em função da excreção de enzimas pelos microorganismos degradadores de pesticidas, as quais em contato com estas moléculas participam de uma série de reações, tais como: oxidação, redução, hidrólise, desalquilação, descarboxilação, hidroxilação, metilação, beta-oxidação, desalcoxilação etc. (Lavorenti, 1996).

Vários são os fatores que afetam a biodegradação de pesticidas no solo como por exemplo o $\mathrm{pH}$, o potencial de oxi-redução, a matéria orgânica do solo etc.. Muitos pesquisadores afirmam que a incorporação de matéria orgânica ao solo aumenta a taxa de degradação dos xenobióticos, entretanto, algumas moléculas são degradadas mais lentamente com o aumento no teor de matéria orgânica no solo (Kearney et al., 1967). Champman \& Harris (1980) observaram que a taxa de degradação do clorperifós foi maior no solo arenoso do que no esterco, o que pode ter ocorrido em função do maior potencial de adsorção no segundo tratamento. Entretanto, foi mostrado que a degradação mais rápida de compostos orgânicos na presença de restos de materiais vegetais está relacionada com a atividade microbiana (Felsot \& Dzantor, 1990).

A adição de material vegetal pode demonstrar também que a degradação pode ocorrer por cometabolismo. Em outras palavras, a energia derivada de outros nutrientes adicionados leva ao metabolismo, do qual pouca ou nenhuma energia pode ser ganha (Anderson, 1990). Na degradação do pesticida por cometabolismo ocorrem reações que não suportam crescimento microbiano.

Costa (1992) estudou a degradação de ${ }^{14} \mathrm{C}$-ametrina, radiomarcada nos carbonos do anel, em solo Areia Quartzosa, amostrado em região próxima de Piracicaba-SP. Utilizou condições de solo esterilizado, não esterilizado e com adição de folhas secas de cana-de-açúcar cultivada em solo tratado ou não com o mesmo herbicida, nos três anos 
anteriores a coleta. Em solos esterilizados, praticamente não foi observado o despreendimento de ${ }^{14} \mathrm{CO}_{2}$. Com a adição de material vegetal oriundo de campos tratados e não tratados, a proporção de ${ }^{14} \mathrm{CO}_{2}$ despreendido foi de 12 e 13 vezes maior, respectivamente, do que em solo sem a adição de substrato, mostrando que a degradação da ametrina ocorre principalmente por cometabolismo. A adição de solo rizosférico da mesma cultura, com e sem tratamentos anteriores do herbicida também aumentou a degradação, com despreendimento de ${ }^{14} \mathrm{CO}_{2}$ de 3,5 e 1,7 vezes maior nos solos tratados e não tratados, respectivamente. Isso mostrou a ocorrência de seleção de microorganismos durante os três anos consecutivos de aplicação do herbicida no campo.

Estudando a persistência dos herbicidas ametrina, atrazina e prometrina em 13 solos de Porto Rico, Liu \& Cibes-Viadé (1972) relataram que os solos com maiores teores de argila e matéria orgânica foram onde os herbicidas apresentaram maior persistência. A ametrina foi o herbicida que menos degradou.

Leon et al. (1978) verificaram em seu trabalho sobre degradação de ametrina em um vertisol de Guanacaste, Costa Rica, tratado por 6 anos consecuitivos com o produto GESAPAX 80 na dose de $3 \mathrm{~kg} \mathrm{ha}^{-1}$, a existência de até $1,10 \mu \mathrm{g} \mathrm{g}^{-1}$ de resíduos de ametrina 240 dias após a última aplicação da molécula. Também relataram que a degradação do herbicida nas condições estudadas foi lenta, aproximadamente $0,1 \mu \mathrm{g} \mathrm{g}$ a cada 20 dias. A alta persistência da ametrina no solo também foi constatada por Compte (1997), que após os 63 dias de incubạção não observou a formação de metabólitos decorrentes da degradação do produto original.

A persistência da ametrina e atrazina em solos com 3,62 \% de matéria orgânica, onde se aplicou 6 e $12 \mathrm{~kg} \mathrm{ha}^{-1}$ de atrazina e 3 a $6 \mathrm{~kg} \mathrm{ha}^{-1}$ de ametrina em estações de chuva e seca, foi estudada por Calero et al. (1984). Foi verificado que as perdas dos herbicidas na camada superior a $10 \mathrm{~cm}$ foram rápidas, isto é, alguns dias após a aplicação a persistência de ambos os compostos foi reduzida, na época de chuva, e a ametrina foi dissipada mais rapidamente que a atrazina. Provavelmente, isto pode estar relacionado com a atividade bioquímica da microbiota heterotrófica do solo, que é assumida como o principal agente responsável pela dissipação dos herbicidas 
pertencentes ao grupo dos derivados da uréia no solo (Hill et al., 1955; Sheets, 1964; Attaway et al., 1982 e Vroumsia et al., 1996).

Vroumsia et al. (1996), estudaram a biodegradação de chlortoluron, diuron e ișoproturon por fungos do solo. Eles cultivaram fungos em soluções com herbicidas como fonte única de energia e concluíram que existe uma variação tanto para os grupos taxonômicos como para as espécies de fungos na degradação destas moléculas. Observaram ainda que a Rhizoctonia solani foi a única espécie de fungo capaz de degradar mais de $70 \%$ de cada uma das moléculas, contudo seu desenvolvimento foi diminuído quando o diuron foi usado como substrato. Neste estudo, o isoproturon foi o herbicida mais rapidamente degradado e o diuron foi o que sofreu menor biodegradação. Resultado semelhante também foi constatado por Cox et al. (1996).

Em estudos referentes a persistência de ametrina, atrazina, simazina e diuron, nas doses de $3,5 \mathrm{~kg} \mathrm{ha}^{-1}$, bem como de tebutiuron, na dose de $1,5 \mathrm{~kg} \mathrm{ha}^{-1}$, em um solo argiloso sob condições naturais, utilizando pepino e aveia como plantas testes de níveis residuais, Blanco et al. (1982) verificaram que a simazina foi degradada mais rapidamente, seguida pela atrazina e diuron, não sendo encontrado resíduo tóxico após 60 dias do tratamento. A ametrina foi dissipada após 90 dias da aplicação e o tebutiuron permeneceu no solo por mais de 1 ano.

A aplicação de herbicidas em mistura com vinhaça e a aplicação pelo sistema convencional em soqueira de cana-de-açúcar foi comparada por Buss et al. (1978). Os autores constataram que à exceção do diuron, que apresentou resultados altamente negativos no controle das plantas daninhas, os demais herbicidas não foram prejudicados quando aplicados com a vinhaça. O 2,4-D e a ametrina melhoraram suas ações no controle e seus efeitos residuais aumentaram, quando aplicados em mistura com a vinhaça. O tebutiuron e orizalin apresentaram comportamentos semelhantes no controle das plantas daninhas, nos dois sistemas de aplicação. 


\subsection{Adsorção de herbicidas}

A adsorção é um processo interfacial e refere-se à adesão ou atração de uma ou mais camadas iônicas ou moleculares para uma superficie, ao contrário da dessorção, fenômeno inverso da adsorção, isto é, quando ocorre a liberação das camadas iônicas ou moleculares presas à superfície para a solução (Lavorenti, 1996).

Forças físicas, pontes de hidrogênio, força eletrostática, ligações de coordenação e interações hidrofóbicas são os principais processos envolvidos na adsorção de moléculas de pesticidas (Bailey \& White, 1970). A força de Van der Walls é muito importante na adsorção das moléculas orgânicas dos pesticidas por se tratar de moléculas geralmente grandes, as quais apresentam um alto momento dipolar, o que as tornam fortemente atraídas por esse mecanismo de força física. Isto também é verdadeiro para compostos orgânicos de cadeia longa (Tan, 1993). Pontes de hidrogênio também podem ocorrer se a molécula orgânica tiver grupos $-\mathrm{NH}$ ou $-\mathrm{OH}$ No caso de moléculas que se ionizam, como a ametrina, o processo de adsorção pode ocorrer por forças eletrostáticas, ligações estas também conhecidas como ligações iônicas. As ligações covalentes também são muito importantes no processo de adsorção de pesticidas, pois é por meio destas que são formados os chamados "resíduos ligados" entre os xenobióticos e as substâncias húmicas do solo (Lavorenti, 1997). Estes resíduos ligados, de acordo com a União Internacional de Química Pura e Aplicada (IUPAC) são "resíduos não passíveis de extração".

A fração orgânica dos solos é responsável pela adsorção da maioria dos compostos, principalmente os hidrofóbicos, como os hidrocarbonetos policíclicos aromáticos e outros poluentes não polares. A extensão desta retenção está diretamente correlacionada com a percentagem de carbono no solo e com o coeficiente de partição octanol-água $\left(\mathrm{K}_{\mathrm{ow}}\right)$ da molécula, que é a medida da hidrofobicidade de um composto químiico (Alexander, 1994). Normalmente, quanto maior o teor de matéria orgânica presente na fase sólida, maior a adsorção de moléculas hidrofóbicas. 
A grande variedade de herbicidas usados atualmente representa diferentes classes de compostos químicos que, de acordo com sua ionização, podem ser classificados em iônicos (catiônicos e aniônicos) e não iônicos (Weber, 1972).

As triazinas pertencem à classe dos compostos catiônicos, ou básicos, grupo em que se encontra a ametrina, que em solução aquosa comporta-se como base fraca, reagindo com os prótons presentes na solução do solo, tornando-se protonada. A protonação depende do $\mathrm{pH}$ da solução do solo e do $\mathrm{pK}_{\mathrm{a}}$ do pesticida (Weed \& Weber, 1974).

Yamane \& Green (1972) mostraram que a adsorção da ametrina pela montmorilonita aumentou cerca de quatrocentas vezes com uma mudança de pH de 8,4 para 4,3. Quando o sistema adsorvente utilizado foi carvão, a mesma mudança de $\mathrm{pH}$ reduziu a adsorção. O carvão, sendo um constituinte natural de solos cultivados com cana-de-açúcar no Havaí, aumenta a adsorção das triazinas, mas reverte o efeito do $\mathrm{pH}$ na adsorção. Com as argilas do solo, um decréscimo do $\mathrm{pH}$ (próximo ao $\mathrm{pK}_{\mathrm{a}}$ do produto) causa protonação das triazinas, aumentando a adsorção. $\mathrm{O}$ carvão presente nos solos pode aumentar o efeito dessortivo da ametrina adsorvida. Segundo os autores isto é responsável pela maior atividade da molécula observada nos solos com plantação de cana-de-açúcar no Havaí. Barba \& Romanowski (1969), estudando solos da mesma região, observaram que a ametrina adsorveu mais que a atrazina, outra triazina. Posteriormente isto também foi demonstrado por Weber (1970) em estudos com montmorilonita.

Ao contrário das triazinas, estão os herbicidas com caráter de ácido fraco, que são doadores de prótons. Assim, dependendo do $\mathrm{pH}$, estes podem ser adsorvidos por forças eletrostáticas pelos colóides do solo, porém somente quando o solo apresentar balanço de cargas positivo (Weber, 1970). Segundo o mesmo autor, os mecanismos primários da adsorção de compostos ácidos ocorrem via associação de prótons e a adsorção ocorre por forças de Van der Walls, ou seja, o composto é adsorvido na forma molecular, sendo que pontes de hidrogênio podem fazer a ligação entre a forma dissociada do ácido e a superficie do colóide. Entretanto, como o $\mathrm{pH}$ dos solos sob condições de cultivo agrícola dificilmente atinge tais valores, existe uma predisposição 
das moléculas aniônicas em serem repelidas pela carga líquida negativa das camadas superficiais do solo, diminuindo, desta forma, a adsorção por forças eletrostáticas (Rodrigues, 1985; Barriuso et al., 1992 e Regitano, 1994).

Já o grupo dos derivados da uréia, no qual se insere o diuron, pertence a classe dos herbicidas que não se ionizam, apresentando desta forma seu processo de adsorção governado principalmente pela fração orgânica do solo.

Liu et al. (1970), estudando a adsorção do diuron, publicaram que o comportamento sortivo do herbicida foi significativamente correlacionado com o teor de matéria orgânica e a CTC dos solos estudados. Estes resultados também foram constatados por outros autores (Helling, 1971; Grover, 1975; Peck et al., 1980 e Luchini, 1987). Entretanto, em estudos com solos de regiões áridas do Sudão com baixa quantidade de matéria orgânica, Mustafa \& Gamar (1972) encontraram coeficientes de correlação significativos ao nível de probabilidade de 0,01 entre o diuron adsorvido pelos colóides do solo com a capacidade de troca de cátions e superfície específica e ao nível de 0,05 com o carbono orgânico. Publicaram ainda que a CTC, superfície específica e percentagem de argila contribuíram com $78,5 \%, 75,4 \%$ e $59,3 \%$ respectivamente na adsorção deste herbicida.

Estudando cinética de adsorção e dessorção de diuron e isoproturon em solo argilo-siltoso, Gaillardon (1996) mostrou que a maior parte do processo de adsorção ocorre até o primeiro dia de equilíbrio com a solução do solo, entretanto, o equilíbrio total ocorre cerca de 1 mês após a aplicação. Evidências de que o processo de adsorção continua ocorrendo, em baixa quantidade, após o período de 24 horas de equilíbrio, período de agitação utilizado em estudos envolvendo adsorção do diuron (Luchini, 1987), também foram constatadas por outras pesquisas deste mesmo autor (Gaillardon et al., 1991 e Gaillardon, 1997). Todavia, esta continuação do processo de adsorção do diuron após o primeiro dia de equilíbrio parece não ser relevante para os estudos de adsorção desse herbicida. 


\subsection{Efeito da vinhaça nas propriedades químicas e biológicas do solo}

\subsection{1 pH e acidez trocável}

A preocupação com os efeitos da vinhaça sobre o solo data das primeiras décadas deste século, como constatado por Ross \& Froberville (1928). Já na metade do século, bem antes do início dos tempos áureos da cana-de-açúcar no Brasil, Almeida et al. (1950) observaram que a aplicação de doses até $1000 \mathrm{~m}^{3} \mathrm{ha}^{-1}$ de vinhaça promovia um acréscimo no $\mathrm{pH}$ do solo. Estes resultados contrariavam as expectativas da época, todavia foram confirmados em estudos posteriores realizados por Almeida (1952), onde foi utilizado $500 \mathrm{~m}^{3} \mathrm{ha}^{-1}$ de vinhaça sulfúrica e pentaclorofenolina.

Dentro deste contexto, Almeida (1953) propôs a primeira explicação para o incremento no valor do $\mathrm{pH}$ de solos que receberam vinhaça: o aumento da população microbiana que, atacando a matéria orgânica e decompondo-a parcialmente, seria a causa da diminuição da acidez do solo.

Os trabalhos citados anteriormente foram de grande importância, visto o pioneirismo destes nos estudos de aplicação de vinhaça ao solo. Todavia, as elevadas dosagens utilizadas, o pequeno conhecimento de outros efeitos deste resíduo e o momento não muito oportuno, diferentemente do final da década de 70 e início da de 80 quando ocorreu o grande pico da cana-de-açúcar, fizeram com que o uso da vinhaça em solos agrícolas não se generalizasse.

Entretanto, com o incentivo à produção do álcool - PROÁLCOOL, em 1975, intensificação da físcalização no sentido de evitar a poluição dos cursos d'água, em função do aumento da demanda bioquímica de oxigênio (DBO) provocada pelo lançamento da vinhaça, e o grande aumento no custo dos fertilizantes minerais, surgiu a necessidade de novos estudos com o objetivo de se conhecer melhor os efeitos desse resíduo no sistema solo-planta.

Desta forma, vários experimentos foram conduzidos confirmando, de uma maneira geral, os resultados obtidos na década de 50 , onde a vinhaça promovia uma 
elevação do pH do solo (Glória \& Magro, 1976; Camargo et al., 1984; Cambuim \& Cordeiro, 1986, Camargo et al., 1987 e Reis \& Rodella, 1998).

Embora os trabalhos citados anteriormente, tenham mostrado a diminuição da acidez dos solos tratados com vinhaça, Rezende (1979) verificou um incremento no $\mathrm{pH}$ após 15 dias da aplicação da vinhaça. Contudo, esta tendência não foi confirmada quando a amostragem de solo foi efetuada aos 60 e 120 dias após a aplicação do resíduo. Estes resultados foram corroborados pelos obtidos por Lima (1980), em estudos com solo Podzólico Vermelho Amarelo incubado com as doses de $150 \mathrm{e} 300 \mathrm{~m}^{3} \mathrm{ha}^{-1}$.

Comparando a relação entre a incorporação de vários materiais orgânicos com o pH e o alumínio trocável do solo, Reis \& Rodella (1998) constataram que a vinhaça, aplicada em dose suficiente para elevar em 0,2 unidades os teores de carbono do solo, causou aumento de uma unidade no valor do $\mathrm{pH}$ aos 100 dias após sua aplicação, decrescendo posteriormente, e uma queda de 18 para aproximadamente $0 \mathrm{mmol}_{\mathrm{c}} \mathrm{dm}^{-3}$ nos teores de Al trocável. Eles sugeriram como explicação para o fenômeno, o fato de cerca de $90 \%$ do carbono da vinhaça ser solúvel, e assim participar de processos que não ocorrem com as formas sólidas de carbono de outros materiais orgânicos.

Vários outros trabalhos também demostraram que a aplicação de vinhaça reduz as concentrações de alumínio trocável (Rezende, 1979; Rodella et al., 1983; Camargo et al., 1984; Cambuim \& Cordeiro, 1986 e Camargo et al., 1987). Camargo et al. (1984) atribuíram este efeito da vinhaça sobre a acidez trocável, a introdução de cátions básicos pelo resíduo, tendo em vista a alta correlação entre a elevação do $\mathrm{pH}$ e saturação por bases encontrada por estes autores e a condições anaeróbicas locais. Entretanto, Rodella et al. (1983) atribuíram este fato à complexação do $\mathrm{Al}^{3+}$ pela matéria orgânica.

\subsubsection{Carbono orgânico e bases trocáveis}

Adicionando resíduos de usina e destilaria durante 3 anos consecutivos, Glória \& Magro (1976) observaram um aumento do teor de carbono dos solos estudados. Entretanto, quando a aplicação de vinhaça era interrompida, os teores de $\mathrm{C}$ decresciam $\mathrm{e}$ voltavam aos valores originais. Tal elevação nos teores de carbono do solo também foi 
observada por Ferreira (1980) aos 35 dias após a aplicação de doses de vinhaça até 1600 $\mathrm{m}^{3} \mathrm{ha}^{-1}$ em solos de diferentes texturas, e por Camargo et al. (1984), em um Latossolo Vermelho Escuro textura média tratado por longo tempo com vinhaça e submetido a intercalação de períodos de pousio.

Em contrapartida, Ribeiro \& Sengik (1983) utilizando Latossolos Vermelho Escuro e Vermelho Amarelo do Triângulo Mineiro, não encontraram alterações significativas no conteúdo de carbono destes solos após a aplicação da vinhaça. Este efeito foi atribuído a rápida decomposição da matéria orgânica existente na vinhaça devido ao estímulo à oxidação biológica provocado pela adição do resíduo.

A vinhaça apresenta em sua composição química altos teores de potássio, médios teores de cálcio e magnésio e baixos teores de fósforo (Glória et al. 1973; Rodella \& Parazzi, 1980; Medeiros, 1981; Rodella et al., 1983; Camargo et al., 1984; Cambuim \& Cordeiro, 1986 e Camargo et al., 1987). Desta forma, vários trabalhos evidenciaram que a aplicação de vinhaça ao solo tem promovido aumentos nas concentrações de potássio, cálcio, magnésio, capacidade de troca de cátions, soma de bases, sendo estes aumentos, de maneira geral, proporcionais as quantidades de resíduo adicionadas (Valsechi \& Gomes, 1954; Camargo et al., 1984; Cambuim \& Cordeiro, 1986 e Camargo et al., 1987)

Um ponto importante a ser analisado quando da aplicação de vinhaça ao solo, em relação aos cátions trocáveis, refere-se às altas quantidades de $\mathrm{K}$ em relação aos outros cátions trocáveis. Em trabalhos feitos por Camargo et al. (1984), para solos tratados com vinhaça por longo tempo, foram encontrados valores de $30 \%$ de $\mathrm{K}$ no sistema de troca, que é um valor altíssimo comparado ao recomendado de 5\% (Vitti, 1997). Estes autores também observaram um aumento na capacidade de troca de cátions do solo em função da aplicação da vinhaça. 


\subsubsection{Propriedades biológicas do solo}

A vinhaça constitui-se numa fonte de energia e de carbono para os microorganismos quimiorganotróficos do solo e assim, quando aplicada, pode alterar algumas propriedades biológicas do solo, como a atividade e biomassa microbiana, propriedades estas que são determinantes na biodegradação de pesticidas.

Em estudos desenvolvidos por Lima (1980), empregando doses de vinhaça até $600 \mathrm{~m}^{3} \mathrm{ha}^{-1} \mathrm{em}$ um Podzólico Vermelho Amarelo, foram constatados aumentos na população microbiana do solo, na taxa de decomposição da matéria orgânica, nitrificação, desnitrificação e fixação biológica do N. Este autor também observou que a respiração, medida pelo despreendimento de $\mathrm{CO}_{2}$, aumentou em função do aumento da população microbiana no solo.

Comparando a decomposição da vinhaça incorporada ao solo, na razão de $200 \mathrm{~m}^{3}$ $\mathrm{ha}^{-1}$, num Latossolo Vermelho Amarelo textura média, mantido a 40,60 e $80 \%$ da capacidade de retenção de água, em termos de liberação de $\mathrm{CO}_{2}$, formação de biomassa microbiana e imobilização do nitrogênio adicionado, Minhoni \& Cerri (1987) concluíram que a umidade do solo, à medida que afetou a oxigenação, atuou significativamente nos três processos analisados, proporcionando aumentos com a diminuição da umidade e que a liberação do $\mathrm{CO}_{2}$ foi o processo de maior intensidade na decomposição da vinhaça, sendo que $2 / 3$ do carbono foi despreendido como $\mathrm{CO}_{2}$ e menos de $1 / 3$ assimilado pela biomassa microbiana.

Martinez Cruz et al. (1987) registraram, em solos tratados com vinhaça, um aumento do número de microorganismos quimiorganotróficos, principalmente fungos e bactérias, ocorrendo para os primeiros uma diminuição qualitativa e predomínio dos gêneros celulolíticos. 


\section{MATERIAL E MÉTODOS}

Para execução deste trabalho, foram realizados basicamente 3 experimentos. No primeiro, foi estudado o efeito da vinhaça na biodegradação dos herbicidas, sendo montado 1 ensaio para cada produto. No segundo, estudou-se o efeito da adição deste resíduo em alguns atributos microbiológicos e químicos dos solos, com o intuito de se obter possíveis explicações para os resultados do primeiro experimento e, no último, o efeito da vinhaça na adsorção dos herbicidas foi o objetivo de estudo. Neste, também foi procedido 1 ensaio para cada produto.

\subsection{Local de investigação}

Os experimentos foram conduzidos no Laboratório de Ecotoxicologia do Centro de Energia Nuclear na Agricultura/USP, em Piracicaba, São Paulo.

\subsection{Solos}

Os solos utilizados nos ensaios, escolhidos pela granulometria e teores de matéria orgânica contrastantes, foram classificados como Terra Roxa Estruturada (TR) e Latossolo Vermelho Amarelo (LV), ambos coletados no município de Piracicaba-SP, na profundidade de 0 a $10 \mathrm{~cm}$, apresentando as características químicas e granulométricas descritas nas Tabelas 1 e 2 . 
Tabela 1. Características químicas dos solos Terra Roxa Estruturada e Latossolo Vermelho Amarelo ${ }^{(1)}$.

\begin{tabular}{ccccccccccccc}
\hline Solo & $\mathrm{pH}$ & $\mathrm{C}$ org. & $\mathrm{P}$ & $\mathrm{K}$ & $\mathrm{Ca}$ & $\mathrm{Mg}$ & $\mathrm{Al}$ & $\mathrm{H}+\mathrm{Al}$ & $\mathrm{SB}$ & $\mathrm{T}$ & $\mathrm{V}$ & $\mathrm{m}$ \\
\hline & $\mathrm{H}_{2} \mathrm{O}$ & $\mathrm{g} \mathrm{dm}^{-3}$ & $\mathrm{mg} \mathrm{dm}^{-3}$ & $\ldots \ldots \ldots \ldots \ldots \ldots \ldots \ldots .$. & $\mathrm{mmol}_{\mathrm{c}} \mathrm{dm}^{-3}$ & $\ldots \ldots \ldots \ldots \ldots \ldots \ldots$ & $\ldots . . \%$ & $\ldots . .$. \\
$\mathrm{TR}$ & 6,9 & 14,3 & 23 & 7,4 & 49 & 26 & 0 & 22 & 82,4 & 104,4 & 79 & 0 \\
$\mathrm{LV}$ & 6,0 & 4,0 & 6 & 0,7 & 14 & 5 & 1 & 38 & 19,7 & 57,7 & 34 & 5 \\
\hline
\end{tabular}

${ }^{(1)}$ Análises segundo os critérios do Instituto Agronômico de Campinas

Tabela 2. Características granulométricas dos solos Terra Roxa Estruturada e Latossolo Vermelho Amarelo ${ }^{(1)}$.

\begin{tabular}{|c|c|c|c|}
\hline Solo & Areia & Silte & Argila \\
\hline & ......... & $\mathrm{kg}^{-1}$ & ......... \\
\hline Terra Roxa Estruturada & 280 & 120 & 600 \\
\hline Latossolo Vermelho Amarelo & 700 & 60 & 240 \\
\hline
\end{tabular}

${ }^{(1)}$ Análise de acordo com a metodologia do densímetro

Antes de serem utilizados nos experimentos, os solos foram secos ao ar e passados em peneira com malha de $2 \mathrm{~mm}$.

\subsection{Herbicidas}

Os herbicidas empregados neste estudo foram a ametrina (2-etilamina-4isopropilamina-6-metiltio-s-2,4,6-triazina) grau técnico, com seu correspondente radiomarcado uniformemente nos carbonos do anel $\left({ }^{14} \mathrm{C}\right)$, com atividade específica de $1,35 \mathrm{MBq} \mathrm{mg}{ }^{-1}$, pureza radioquímica de $99 \%$ (após purificação) e solubilidade em água de $42 \mathrm{mg} \mathrm{L}^{-1}$ e o diuron (3-(3,4-diclorofenil)-1,1-dimetilureia) grau técnico, com seu correspondente radiomarcado uniformemente nos carbonos do anel $\left({ }^{14} \mathrm{C}\right)$, com atividade específica de $2,43 \mathrm{MBq} \mathrm{mg}^{-1}$, pureza radioquímica de $98,74 \%$ e solubilidade em água de $62 \mathrm{mg} \mathrm{L}^{-1}$, ambos fornecidos pelo Laboratório de Ecotoxicologia do Centro de Energia Nuclear na Agricultura. 


\subsection{Purificação da ametrina radiomarcada}

A purificação da ametrina foi necessária devido a pureza radioquímica ter sido inferior a $95 \%$. O processo de purificação da ametrina teve início com a aplicação de todo o produto original em placa de cromatografia de camada delgada (TLC), de $10 \times 20$ $\mathrm{cm}$, utilisando-se o aplicador automático Cammag Linomat IV, deixando uma distância de $15 \mathrm{~cm}$ para a eluição do produto. Em seguida, a placa de TLC foi eluída em cuba de vidro $(9,5 \times 27 \times 29 \mathrm{~cm})$ usando-se $100 \mathrm{~mL}$ da mistura tolueno, clorofórmio e acetato de etila, na proporção de 2:2:1 (v/v/v), respectivamente. Após a eluição, a placa foi seca por 30 minutos e, posteriormente, o produto foi localizado com a utilização do Automatic TLC-Linear Analyzer Berthold.

A área da placa onde o produto original localizava-se foi demarcada e, então, procedeu-se a raspagem da sílica da placa em bandeja de aço inox. A sílica raspada foi colocada em frasco de $20 \mathrm{~mL}$, onde foi adicionado diclorometano e levado ao ultra-som Bandelin Sonorex RK510S, por 15 minutos, para que ocorresse a solubilização do produto. O sobrenadante foi transferido para outro frasco de $20 \mathrm{~mL}$ e o solvente foi evaporado por arraste em fluxo de nitrogênio gasoso até secagem completa. Posteriormente o produto foi ressuspendido em $5 \mathrm{~mL}$ de diclorometano, retirando-se alíquotas de $1 \mu \mathrm{L}$ para detecção da radioatividade por espectrometria de cintilação líquida. A pureza final foi de $99 \%$.

\subsection{Preparo da solução do herbicida}

\subsubsection{Estudo da biodegradação}

A quantidade total de ingrediente ativo utilizada neste experimento foi de 0,25 mg $100 \mathrm{~g}^{-1}$ de terra para a ametrina e $0,267 \mathrm{mg} 100 \mathrm{~g}^{-1}$ de terra para o diuron, correspondentes a 3,0 e $3,2 \mathrm{~kg} \mathrm{ha}^{-1}$, respectivamente, considerando a profundidade de 10 $\mathrm{cm}$ e a densidade do solo como $1,2 \mathrm{~g} \mathrm{~cm}^{-3}$. A atividade aplicada para cada $100 \mathrm{~g}$ de terra foi de $11,33 \mathrm{kBq}$ para a ametrina e $25 \mathrm{kBq}$ para o diuron. À partir das atividades 
específicas, calculou-se uma quantidade de $8,39 \mu \mathrm{g}$ da ametrina radiomarcada e mais $0,2416 \mathrm{mg}$ de ingrediente ativo do produto grau técnico para que atingisse os $0,25 \mathrm{mg}$ desejados do ingrediente ativo total em $100 \mathrm{~g}$ de terra e $10,29 \mu \mathrm{g}$ do diuron marcado com o isótopo carbono-14 e mais $0,2567 \mathrm{mg}$ de ingrediente ativo do produto grau técnico para que atingisse os $0,267 \mathrm{mg}$ desejados do ingrediente ativo total em $100 \mathrm{~g}$ de terra. Como haviam 18 frascos com $100 \mathrm{~g}$ de terra cada para cada produto (6 tratamentos, Tabela $4, x 3$ repetições), estas quantidades foram multiplicadas por $18 \mathrm{e}$ solubilizadas em $7,2 \mathrm{~mL}$ de diclorometano e $7,2 \mathrm{~mL}$ de acetona para a ametrina e diuron, respectivamente. Em cada frasco foi aplicado $400 \mu \mathrm{L}$ de solução.

\subsubsection{Estudo da adsorção}

As soluções estoques do principio ativo do herbicida ametrina foram preparadas em diclorometano e do diuron em acetona. Cinco diluições da solução estoque foram preparadas para se obter novas soluçōes com concentrações de 2,$47 ; 5,0 ; 7,5 ; 10,0$ e $12,5 \mu \mathrm{g} \mathrm{mL}^{-1}$ para a ametrina e de 1,$37 ; 2,67 ; 5,0 ; 7,0$ e $10,0 \mu \mathrm{g} \mathrm{mL}^{-1}$ para o diuron.

Os correspondentes marcados com o radioisótopo carbono-14, foram diluídos em cada uma dessas soluções de forma que apresentasse atividade de $0,33 \mathrm{kBq} \mathrm{mL}^{-1}$.

\subsection{Vinhaça}

As características químicas da vinhaça utilizada nos experimentos encontram-se na Tabela 3.

Tabela 3. Características químicas da vinhaça

\begin{tabular}{|c|c|c|c|c|c|c|c|c|}
\hline $\mathrm{pH}$ & $\mathrm{C}^{*}$ & $\mathrm{P}_{2} \mathrm{O}_{5}$ & $\mathrm{~K}_{2} \mathrm{O}$ & $\mathrm{Ca}$ & $\mathrm{Mg}$ & $\mathrm{S}$ & $\overline{\mathrm{N}}$ & $\mathrm{C} / \mathbf{N}$ \\
\hline & $\ldots \ldots$ & . & $\ldots . . \mathrm{g}$ & & & & & \\
\hline 4,30 & 7,47 & 0,10 & 5,10 & 1,18 & 0,42 & 0,96 & 0,70 & 11 \\
\hline
\end{tabular}

*determinado de acordo com o método da combustão 


\subsection{Quantidade de vinhaça aplicada}

As doses de vinhaça empregadas nos experimentos foram equivalentes a $100 \mathrm{e}$ $200 \mathrm{~m}^{3} \mathrm{ha}^{-1}$, baseadas nas recomendações para as soqueiras de cana-de-açúcar.

Considerando a densidade da vinhaça igual a $1 \mathrm{~g} \mathrm{~cm}^{-3}$ e a densidade do solo como $1,2 \mathrm{~g} \mathrm{~cm}^{-3} \mathrm{e}$, tomando-se como base a profundidade de $10 \mathrm{~cm}$, as doses de $100 \mathrm{e}$ $200 \mathrm{~m}^{3} \mathrm{ha}^{-1}$ foram corrigidas para as quantidades de terra utilizadas nos experimentos.

\subsection{Pré-incubação do solo com a vinhaça}

Antes da aplicação dos herbicidas, a vinhaça foi adicionada às amostras de terra, sendo incubados ao ar livre por 4 dias, período aproximado que antecede a aplicação dos herbicidas às soqueiras de cana-de-açúcar.

\subsection{Umidade do solo}

A umidade dos solos foi mantida a $60 \%$ da capacidade de retenção máxima de água do solo, determinada pelo método do torrão separado pela frente de molhamento (Costa, 1983).

\subsection{Procedimento para o estudo da biodegradação}

Para a execução do estudo da biodegradação foram montados 2 experimentos em delineamento experimental inteiramente casualizado, em arranjo fatorial $2 \times 3$, sendo um experimento para o herbicida diuron e outro para a ametrina. Os fatores de tratamento utilizados foram: solos (Terra Roxa Estruturada e Latossolo Vermelho Amarelo) e doses de vinhaça $\left(0,100\right.$ e $\left.200 \mathrm{~m}^{3} \mathrm{ha}^{-1}\right)$.

Os tratamentos utilizados no referido estudo se encontram na Tabela 4. 
Tabela 4. Tratamentos do estudo de biodegradação ${ }^{(1)}$

\begin{tabular}{lcll}
\hline Tratamentos & Vinhaça $\left(\mathrm{m}^{3}\right.$ ha $\left.^{-1}\right)$ & Herbicida & Solo \\
\hline T1 & Experimento 1 & & \\
T2 & 0 & Ametrina & TR \\
T3 & 100 & Ametrina & TR \\
T4 & 200 & Ametrina & TR \\
T5 & 0 & Ametrina & LV \\
T6 & 100 & Ametrina & LV \\
& 200 & Ametrina & LV \\
T1 & Experimento 2 & & \\
T2 & 0 & Diuron & TR \\
T3 & 100 & Diuron & TR \\
T4 & 200 & Diuron & TR \\
T5 & 0 & Diuron & LV \\
T6 & 100 & Diuron & LV \\
\hline
\end{tabular}

${ }^{(1)}$ Todos os tratamentos foram feitos em triplicata.

Em frascos especiais de boca larga de $500 \mathrm{~mL}$ de capacidade, foram adicionados $100 \mathrm{~g}$ de amostra de cada solo. A capacidade máxima de retenção de água foi corrigida a $60 \%$, e foi mantida durante todo o experimento. Em seguida, fez-se a adição das doses de vinhaça, com pré-incubação de 4 dias, antes da aplicação dos herbicidas. Posteriormente, com os herbicidas já aplicados, foi procedida sua homogeneização com o solo e, um frasco de cintilação, sem tampa, contendo $10 \mathrm{~mL}$ de uma solução de $\mathrm{NaOH}$ $0,2 \mathrm{~mol} \mathrm{~L}^{-1}$, foi acondicionado na parte inferior do frasco especial. Os frascos especiais foram hermeticamente fechados e incubados por um período de 120 dias, no escuro e a $25^{\circ} \pm 2^{\circ} \mathrm{C}$. Durante o período de incubação, ${ }^{14} \mathrm{CO}_{2}$ despreendido dos herbicidas foram avaliados nos dias $0,1,7,14,21,28,35,42,49,56,63$ e 120 após a aplicação do herbicida, através da formação do ${ }^{14} \mathrm{C}$-bicarbonato de sódio pela reação química do ${ }^{14} \mathrm{CO}_{2}$ despreendido com $\mathrm{NaOH}$. 


\subsubsection{Determinação do ${ }^{14} \mathrm{CO}_{2}$ despreendido}

Para determinação do ${ }^{14} \mathrm{CO}_{2}$ despreendido, foi retirada uma alíquota de $1 \mathrm{~mL}$ de cada frasco contendo a solução de $\mathrm{NaOH}$ e levada para outro frasco de cintilação com 10 $\mathrm{mL}$ de solução cintiladora (4 $\mathrm{g}$ de PPO; 0,2 de POPOP; $340 \mathrm{~mL}$ de Renex 95 e $660 \mathrm{~mL}$ de tolueno, Mesquita \& Ruegg, 1984). A radioatividade foi detectada durante 10 minutos em espectrofotômetro de cintilação líquida (Beckman-Modelo 1600 TR).

\subsection{Extração dos herbicidas}

Ao final do período de incubação, nos experimentos de biodegradação, foi feita a extração dos herbicidas e seus metabólitos presentes no solo.

Inicialmente, oxidou-se uma alíquota de $300 \mathrm{mg}$ de terra de cada frasco utilizado no estudo da biodegradação, com duas repetições, em Biological Oxidizer OX500 (R. J. Harvey Instrument Corporation), procedendo-se, em seguida, a detecção da radioatividade total presente nas amostras antes da extração por espectrofotometria de cintilação líquida, com a finalidade de detectar a radioatividade total presente na amostra, antes da extração.

A massa de solo contido nos frascos utilizados no estudo da biodegradação, foi dividida em duas partes de $50 \mathrm{~g}$ e acondicionadas em tubo de centrífuga de $250 \mathrm{~mL}$. Adicionou-se $100 \mathrm{~mL}$ de metanol e manteve-se os tubos de centrífuga em agitação, a $120 \mathrm{rpm}$, por duas horas. As amostras foram centrifugadas a $10.000 \mathrm{rpm}$ durante 15 minutos e o sobrenadante foị reservado. Juntou-se os sobrenadantes das duas porções ( $50 \mathrm{~g}$ ) de cada amostra. Repetiu-se o processo por duas vezes, porém com agitação por 30 minutos, obtendo-se no final $600 \mathrm{~mL}$ de sobrenadante. De cada repetição, pipetou-se $300 \mu \mathrm{L}$ para frasco de cintilação, adicionou-se $10 \mathrm{~mL}$ de solução cintiladora e avaliou-se

a radioatividade extraída, durante 10 minutos, por espectrofotometria de cintilação líquida. 


\subsection{Cromatografia de camada delgada (TLC)}

Os volumes de sobrenadantes extraidos $(600 \mathrm{~mL})$ foram evaporados em rotavapor até aproximadamente $10 \mathrm{~mL}$ que, por arraste em fluxo de nitrogênio, foram secos completamente e ressuspendidos em $5 \mathrm{~mL}$ de metanol. Então procedeu-se a identificação dos herbicidas e seus metabólitos utilizando-se a técnica de cromatografia de camada delgada.

Aplicou-se uma alíquota de $200 \mu \mathrm{L}$ de cada extrato em placa de cromatografia de camada delgada (sílica gel $60 \mathrm{~F} 245$, Merk) e $1 \mu \mathrm{L}$ do padrão (solução estoque do herbicida radiomarcado). A eluição das placas foi feita por um sistema de solventes constituído de tolueno-clorofórmio-acetato de etila $(2: 2: 1, \mathrm{v} / \mathrm{v} / \mathrm{v})$ para a ametrina e hexano-acetona $(6: 4, \mathrm{v} / \mathrm{v})$ para o diuron, utilizando-se um volume de $100 \mathrm{~mL}$ de solvente. Após a eluição, as placas foram secas ao ar por 30 minutos e a detecção dos metabólitos foi procedida com a utilização do Automatic TLC-Linear Analyzer Berthold, durante 15 minutos.

\subsection{Atividade microbiana}

Para a avaliação da atividade microbiana, montou-se um experimento em arranjo fatorial com: 2 solos (Terra Roxa Estruturada e Latossolo Vermelho Amarelo), 2 doses de vinhaça (100 e $200 \mathrm{~m}^{3} \mathrm{ha}^{-1}$ ), 3 fatores para herbicidas (diuron, ametrina e sem herbicida) e uma testemunha (somente os solos). O experimento foi montado com duas repetições e as avaliações foram feitas nos dias $0,4,11,18,25,32$ e 63 após a instalação do experimento, pelo método da ${ }^{14} \mathrm{C}$-glicose (Freitas et al., 1979).

A atividade microbiana ( $\mu \mathrm{mol}{ }^{14} \mathrm{C}$-glicose. $\mathrm{g}^{-1}$ solo seco. $\mathrm{h}^{-1}$ ) foi calculada pela seguinte fórmula:

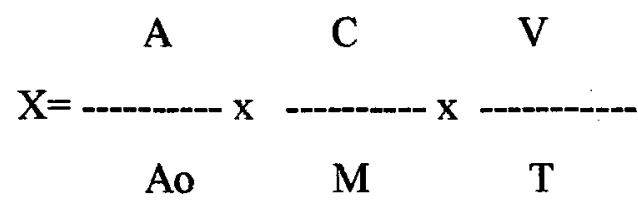


na qual,

$\mathrm{X}=\mu \mathrm{mol}^{14} \mathrm{C}$-glicose $\mathrm{g}^{-1}$ solo seco $\mathrm{h}^{-1}$

A = Atividade da amostra (dpm)

Ao $=$ Atividade do padrão (dpm)

$\mathrm{C}=$ Concentração da solução de ${ }^{14} \mathrm{C}$-glicose $\left(\mu \mathrm{mol} \mathrm{mL}{ }^{-1}\right)$

$\mathrm{M}=$ Massa de solo seco $(\mathrm{g})$

$\mathrm{V}=$ Volume da solução de ${ }^{14} \mathrm{C}$ - glicose $(\mu \mathrm{L})$

$\mathrm{T}=$ Tempo de incubação $(\mathrm{h})$

Nas amostras de solo remanescentes deste experimento, foram feitas análises de carbono por combustão seca e $\mathrm{pH}$ em $\mathrm{H}_{2} \mathrm{O}$, nos mesmos períodos que a atividade microbiana.

\subsection{Biomassa microbiana}

Paralelo ao ensaio da atividade microbiana, determinou-se a biomassa dos microrganismos logo após a aplicação dos herbicidas e ao término do experimento (63 dias após a aplicação dos herbicidas), em todos os tratamentos, porém, sem a utilização de repetições, através do método de fumigação-extração (FE) descrito por Vance et al. (1987).

\subsection{Procedimento para o estudo da adsorção}

Os testes de adsorção dos herbicidas ametrina e diuron foram feitos nas amostras de solo tratadas com $0 ; 100$ e $200 \mathrm{~m}^{3} \mathrm{ha}^{-1}$ de vinhaça. Os tratamentos utilizados neste estudo foram os mesmos utilizados para o estudo da biodegradação (Tabela 4). Entretanto, para cada tratamento foram utilizadas 5 concentrações do produto (ítem 3.5.2). 
$\mathrm{O}$ experimento foi conduzido com três repetições e um branco (solução de $\mathrm{CaCl}_{\mathbf{2}}$ $0,01 \mathrm{~mol} \mathrm{~L}^{-1}$ com herbicida sem solo), que serviu de padrão para todas as concentrações de cada herbicida.

Amostras de $1 \mathrm{~g}$ de cada solo, foram transferidas para tubos de centrífuga de 50 $\mathrm{mL}$, onde foram adicionados $10 \mathrm{~mL}$ de solução de $\mathrm{CaCl} 0,01 \mathrm{~mol} \mathrm{~L}^{-1}$. Posteriormente, foram aplicados os herbicidas nas 5 concentrações pré-determinadas. Os tubos foram fechados e agitados por 24 horas em agitador horizontal (120 rpm). Após este período, os tubos foram centrifugados a $2.500 \mathrm{rpm}$ durante 10 minutos. Alíquotas de $1 \mathrm{~mL}$ dos sobrenadantes foram transferidas para frascos de cintilação, contendo $10 \mathrm{~mL}$ de solução cintiladora, quantificando-se a radioatividade das amostras por espectrofotometria de cintilação líquida. A quantidade de herbicida adsorvido foi determinada pela diferença entre a concentração da solução padrão (branco) e a concentração do herbicida na solução após atingir o equilíbrio com o solo

\subsection{Cálculo da quantidade de herbicida adsorvido}

A quantidade de herbicida adsorvido em $1,0 \mathrm{~g}$ de solo, para cada concentração estudada, foi determinada pela seguinte equação:

$$
A_{S}=V / M\left(C_{b}-C_{e}\right)
$$

Na qual:

$A_{S}=$ quantidade de herbicida adsorvido por massa de solo $\left(\mu \mathrm{g} \mathrm{g}^{-1}\right)$

$\mathrm{V}=$ volume de solução de herbicida adicionado $(\mathrm{mL})$

$\mathrm{M}=$ massa de solo $(\mathrm{g})$

$\mathrm{C}_{\mathrm{b}}=$ concentração de herbicida na solução padrão (branco) $\left(\mu \mathrm{g} \mathrm{mL}{ }^{-1}\right)$

$\mathrm{C}_{\mathrm{e}}=$ concentração de herbicida na solução em equilibrio com o solo $\left(\mu \mathrm{g} \mathrm{mL}^{-1}\right)$ 


\subsection{Isotermas de adsorção}

As isotermas de adsorção representam a relação entre a quantidade de um herbicida adsorvido, em diferentes concentrações, e a sua quantidade remanescente nas soluções após equilíbrio com o solo, a temperatura constante.

$\mathrm{O}$ modelo matemático de Freundlich tem sido o mais utilizado para descrever estas relações. Segundo este modelo temos:

$$
A=K_{f} \cdot C_{e}^{1 / n}
$$

Sendo a forma linear desta equação dada por:

$$
\log A=\log K_{f}+1 / n \log C_{e}
$$

na qual:

$$
\begin{aligned}
& \mathrm{A}=\text { quantidade do herbicida adsorvido }\left(\mu \mathrm{g} \mathrm{g}^{-1}\right) \\
& \mathrm{C}_{\mathrm{e}}=\text { concentração do herbicida na solução em equilíbrio com o solo }\left(\mu \mathrm{g} \mathrm{mL}^{-1}\right) \\
& \mathrm{K}_{\mathrm{f}}=\text { coeficiente de adsorção } \\
& 1 / \mathrm{n}=\text { grau de linearidade da adsorção. }
\end{aligned}
$$

\subsection{Estatística}

As análises estatísticas foram feitas com a utilização do programa SAS. Para os dados de despreendimento de ${ }^{14} \mathrm{CO}_{2}$ acumulado foram procedidas análises de variância e comparação de médias pelo teste $t$, ao nível de significância de 0,01 . Para os resultados de despreendimento de ${ }^{14} \mathrm{CO}_{2}$ semanal, no estudo da biodegradação, para os de carbono orgânico e para os de concentração de equilíbrio e quantidade adsorvida, no estudo da adsorção, foram calculados o desvio padrão da média e coeficiente de variação. 


\section{RESULTADOS E DISCUSSÃo}

\subsection{Biodegradação}

A Tabela 5 apresenta os dados de porcentagem acumulada de ${ }^{14} \mathrm{CO}_{2}$ despreendido do herbicida diuron. A adição de vinhaça ao solo TR proporcionou um aumento significativo no despreendimento de ${ }^{14} \mathrm{CO}_{2}$ deste herbicida, o que possibilita inferir que a vinhaça contribuiu para uma maior biodegradação da molécula até 120 dias após sua aplicação (Tabela 5).

Tabela 5. Porcentagem acumulada de ${ }^{14} \mathrm{CO}_{2}$ despreendido do herbicida diuron nos solos Terra Roxa Estruturada (TR) e Latossolo Vermelho Amarelo (LV).

\begin{tabular}{|c|c|c|c|c|}
\hline \multirow[t]{2}{*}{ Dias após aplicação } & \multirow[t]{2}{*}{ Solo } & \multicolumn{3}{|c|}{$\ldots \ldots \ldots \ldots \ldots . . . . . . . . \ldots$} \\
\hline & & 0 & 100 & 200 \\
\hline \multirow[t]{2}{*}{28} & TR & $6,27 \mathrm{bA}^{*}$ & $10,89 \mathrm{aA}$ & $11,64 \mathrm{aA}$ \\
\hline & LV & $1,30 \mathrm{aB}$ & $1,34 \mathrm{aB}$ & $1,38 \mathrm{aB}$ \\
\hline \multirow[t]{2}{*}{63} & TR & $11,07 \mathrm{cA}$ & $\begin{array}{c}0,20 \\
37,20 \mathrm{bA}\end{array}$ & 59,77 aA \\
\hline & LV & $2,44 \mathrm{aB}$ & $2,56 \mathrm{aB}$ & $2,91 \mathrm{aB}$ \\
\hline \multirow[t]{2}{*}{120} & TR & $15,12 \mathrm{cA}$ & $37,20 \mathrm{bA}$ & $59,77 \mathrm{aA}$ \\
\hline & LV & $3,47 \mathrm{aB}$ & $3,67 \mathrm{aB}$ & $4,19 \mathrm{aB}$ \\
\hline
\end{tabular}

*Letras minúsculas e maiúsculas iguais nas linhas e colunas, respectivamente, indicam não haver diferença entre tratamentos ao nível de significância de 0,01 pelo teste $t$. 
A avaliação semanal do despreendimento de ${ }^{14} \mathrm{CO}_{2}$ do diuron até 63 dias após a aplicação, no solo TR, mostrou que a dose de vinhaça de $200 \mathrm{~m}^{3} \mathrm{ha}^{-1}$ proporcionou um maior despreendimento do ${ }^{14} \mathrm{CO}_{2}$ que a dose de $100 \mathrm{~m}^{3} \mathrm{ha}^{-1}$, que por sua vez proporcionou um despreendimento mais pronunciado que o tratamento que não recebeu vinhaça (Figura 1). Esta tendência prosseguiu até os 120 dias após a aplicação do herbicida, quando cerca de $60 \%$ do diuron aplicado foi degradado, no tratamento com maior dose do resíduo (Tabela 5).

No solo LV não foi observado nenhuma alteração significativa no despreendimento de ${ }^{14} \mathrm{CO}_{2}$ do diuron em função da presença de vinhaça ao final de 28 , 63 e 120 dias (Tabela 5), sendo este sempre inferior ao ocorrido no TR em todos os tratamentos e períodos de avaliação (Figura 1).

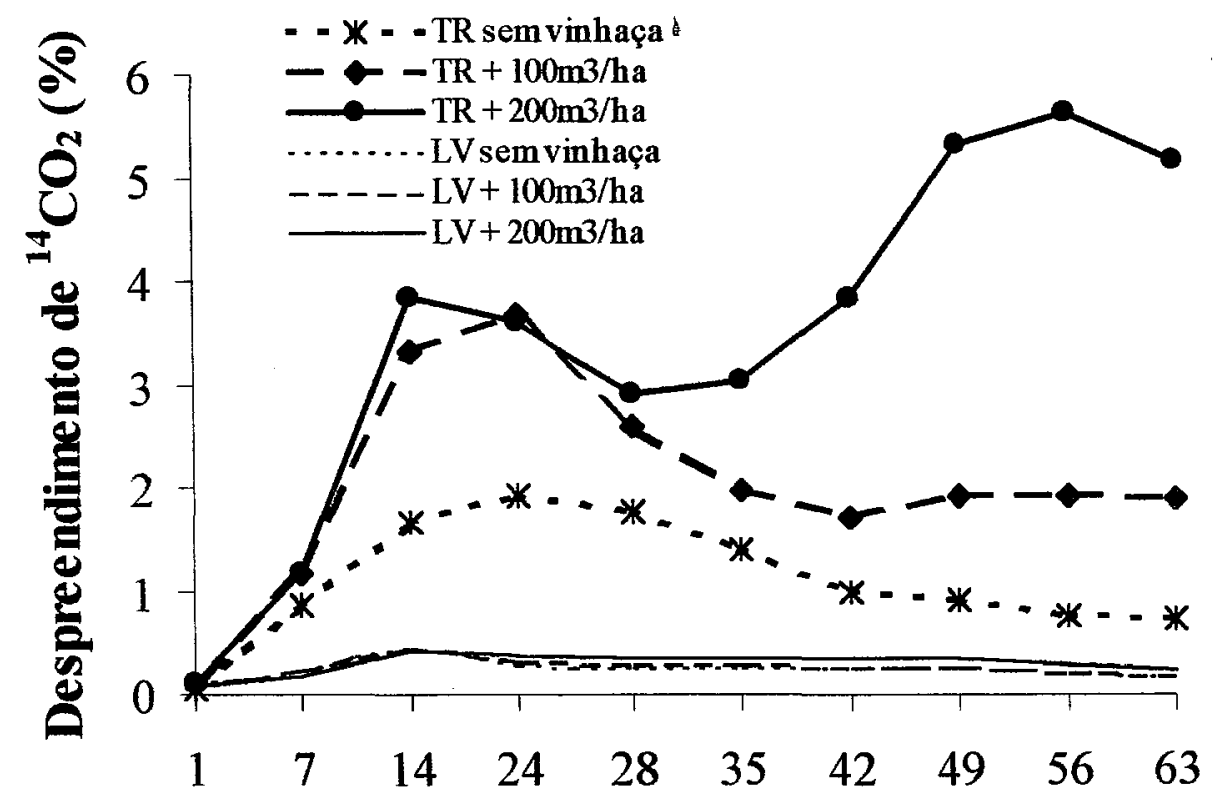

\section{Dias}

Figura 1. Despreedimento de ${ }^{14} \mathrm{CO}_{2}$ do diuron nos solos Terra Roxa Estruturada (TR) e Latossolo Vermelho Amarelo (LV), incubados com vinhaça até 63 dias.

Provavelmente, a adição da vinhaça não influenciou na biodegradação do diuron neste solo pela ausência de espécies microbianas capazes de degradar esta 
molécula, já que a vinhaça contribuiu com o aumento da atividade e biomassa microbiana (Figuras 4 e 5 ).

A Tabela 6 apresenta os dados da porcentagem acumulada de ${ }^{14} \mathrm{CO}_{2}$ despreendido do herbicida ametrina.

Tabela 6. Porcentagem acumulada de ${ }^{14} \mathrm{CO}_{2}$ despreendido da ametrina nos solos Terra Roxa Estruturada (TR) e Latossolo Vermelho Amarelo (LV).

\begin{tabular}{ccccc}
\hline Dias após aplicação & Solo & $\ldots \ldots \ldots \ldots \ldots .$. & Dose de vinhaça $\left(\mathrm{m}^{3} \mathrm{ha}^{-1}\right)$ & $\ldots \ldots \ldots \ldots \ldots \ldots$ \\
& & 0 & 100 & 200 \\
\hline 28 & TR & $0,98 \mathrm{cA}^{*}$ & $1,22 \mathrm{bA}$ & $1,72 \mathrm{aA}$ \\
& LV & $0,09 \mathrm{aB}$ & $0,20 \mathrm{aB}$ & $0,04 \mathrm{aB}$ \\
& & & & \\
63 & TR & $4,47 \mathrm{bA}$ & $4,95 \mathrm{bA}$ & $7,17 \mathrm{aA}$ \\
& LV & $0,21 \mathrm{bB}$ & $2,11 \mathrm{aB}$ & $0,52 \mathrm{bB}$ \\
& & & & \\
120 & TR & $24,83 \mathrm{bA}$ & $28,67 \mathrm{aA}$ & $22,94 \mathrm{bA}$ \\
& LV & $0,43 \mathrm{bB}$ & $7,55 \mathrm{aB}$ & $1,84 \mathrm{bB}$
\end{tabular}

* Letras minúsculas e maiúsculas iguais nas linhas e colunas, respectivamente, indicam não haver diferença entre tratamentos ao nível de significância de 0,01 pelo teste $t$.

$\mathrm{O}$ despreendimento de ${ }^{14} \mathrm{CO}_{2}$ da ametrina, no TR, foi mais elevado nos tratamentos que receberam a dose de $200 \mathrm{~m}^{3} \mathrm{ha}^{-1}$ de vinhaça, seguido dos que receberam $700 \mathrm{~m}^{3} \mathrm{ha}^{-1} \mathrm{e}$ dos que não receberam. Entretanto, isto foi observado somente até 56 dias após a aplicação do produto, período após o qual o despreendimento do ${ }^{14} \mathrm{CO}_{2}$ do tratamento que não recebeu vinhaça foi superior aos outros tratamentos (Figura 2). Aos 120 dias após a aplicação do herbicida, a degradação da ametrina seguiu a seguinte ordem: $100 \mathrm{~m}^{3}$ ha $^{-1}>$ sem vinhaça $=200 \mathrm{~m}^{3}$ ha ${ }^{-1}$ (Tabela 6).

A dose do resíduo de $100 \mathrm{~m}^{3} \mathrm{ha}^{-1}$ também proporcionou as maiores taxas de despreendimento de ${ }^{14} \mathrm{CO}_{2}$ da ametrina no solo LV (Figura 2). Ao término da condução do experimento (120 dias), este efeito continuou sendo observado com diferenças

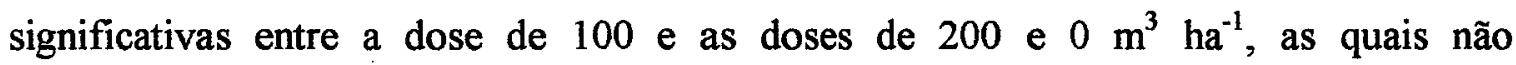
apresentaram diferenças entre si (Tabela 6). 


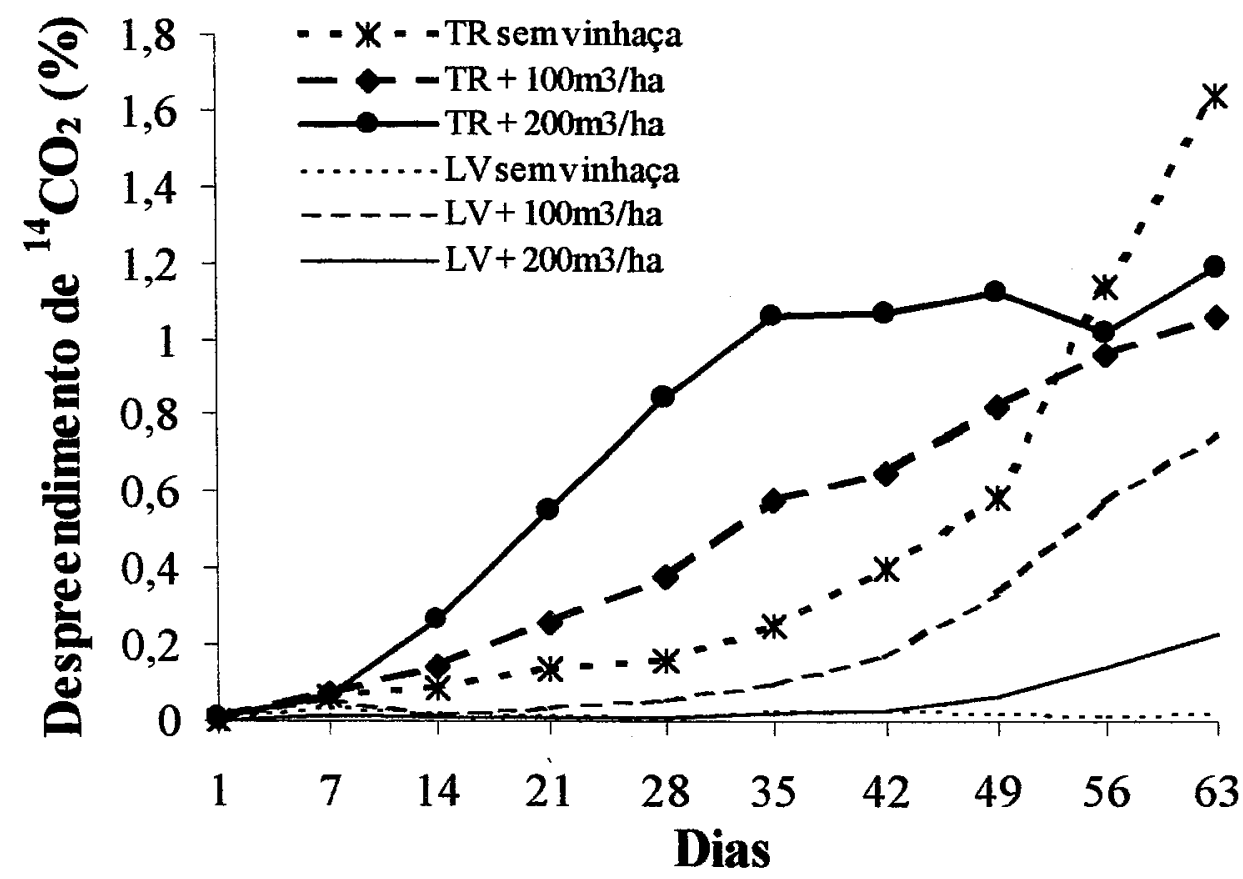

Figura 2. Despreendimento de ${ }^{14} \mathrm{CO}_{2}$ da ametrina nos solos Terra Roxa Estruturada (TR) e Latossolo Vermelho Amarelo (LV), incubados com vinhaça até 63 dias.

Pelos resultados obtidos para a degradação da ametrina ao final de 120 dias, pode-se sugerir que doses de vinhaça de $200 \mathrm{~m}^{3} \mathrm{ha}^{-1}$ possam estar contribuindo com o aumento da persistência da molécula, provavelmente pela inibição de grupos de microorganismos que promovam sua degradação em determinados períodos, visto que o despreendimento de ${ }^{14} \mathrm{CO}_{2}$ até 63 dias foi maior na dose 200 que na dose 100 , no TR (Tabela 6).

A persistência da ametrina em solos foi classificada como média por Rodrigues \& Almeida (1995), entretanto, estes autores sugeriram que esta classificação poderia variar conforme o tipo de solo e as condições climáticas. Já nos estudos de Compte (1997), onde a ametrina praticamente não foi degradada, sua persistência foi classificada como alta.

Considerando 28 dias de incubação, os resultados obtidos para a degradação da ametrina estão de acordo com os encontrados por Costa (1992), onde foi observada uma 
alteração na classificação quanto a persistência do produto nos tratamentos que receberam material vegetal proveniente de solos que foram tratados ou não com o herbicida e também nos que receberam solo rizosférico advindo de áreas que já haviam recebido o produto. Nestes tratamentos, a persistência passou a ser classificada como média, já que na testemunha foi classificada como alta.

Os efeitos da matéria orgânica na biodegradação de pesticidas tem sido abordados por vários autores (Champman \& Harris, 1980; Castro \& Yoshida, 1974; Musumeci \& Ruegg, 1984; Costa, 1992; Cox, 1996; Vroumsia, 1996). Eles observaram que a matéria orgânica pode aumentar ou diminuir a biodegradação de moléculas de pesticidas por ativar a microbiota heterotrófica do solo em alguns casos e, em outros, por favorecer os processos de adsorção.

Resultados semelhantes aos encontrados neste trabalho, para a biodegradação da ametrina durante 63 dias, também foram obtidos por Costa (1992), que observou o efeito positivo da matéria orgânica na degradação deste herbicida.

A maior porcentagem de degradação do diuron no TR e da ametrina nos dois solos com a adição de vinhaça, provavelmente, devem-se ao aumento da atividade e da biomassa microbiana nestas condições (Figuras 3, 4 e 5).

Em todos os tratamentos, a atividade microbiana foi um pouco superior no solo TR (Figura 3) em relação ao LV (Figura 4), o que explica, em parte, a maior degradação das moléculas de diuron e ametrina neste tipo de solo. Também foi observado que a adição de vinhaça, em ambos os solos, aumentou a atividade e a biomassa microbiana (Figuras 3, 4 e 5), sendo este aumento mais pronunciado onde foi adicionada a maior dose do resíduo, como era esperado. Este efeito da vinhaça nessas propriedades biológicas do solo também foi observado por outros autores (Lima, 1980; Minhoni \& Cerri, 1987 e Martinez Cruz, 1987). 


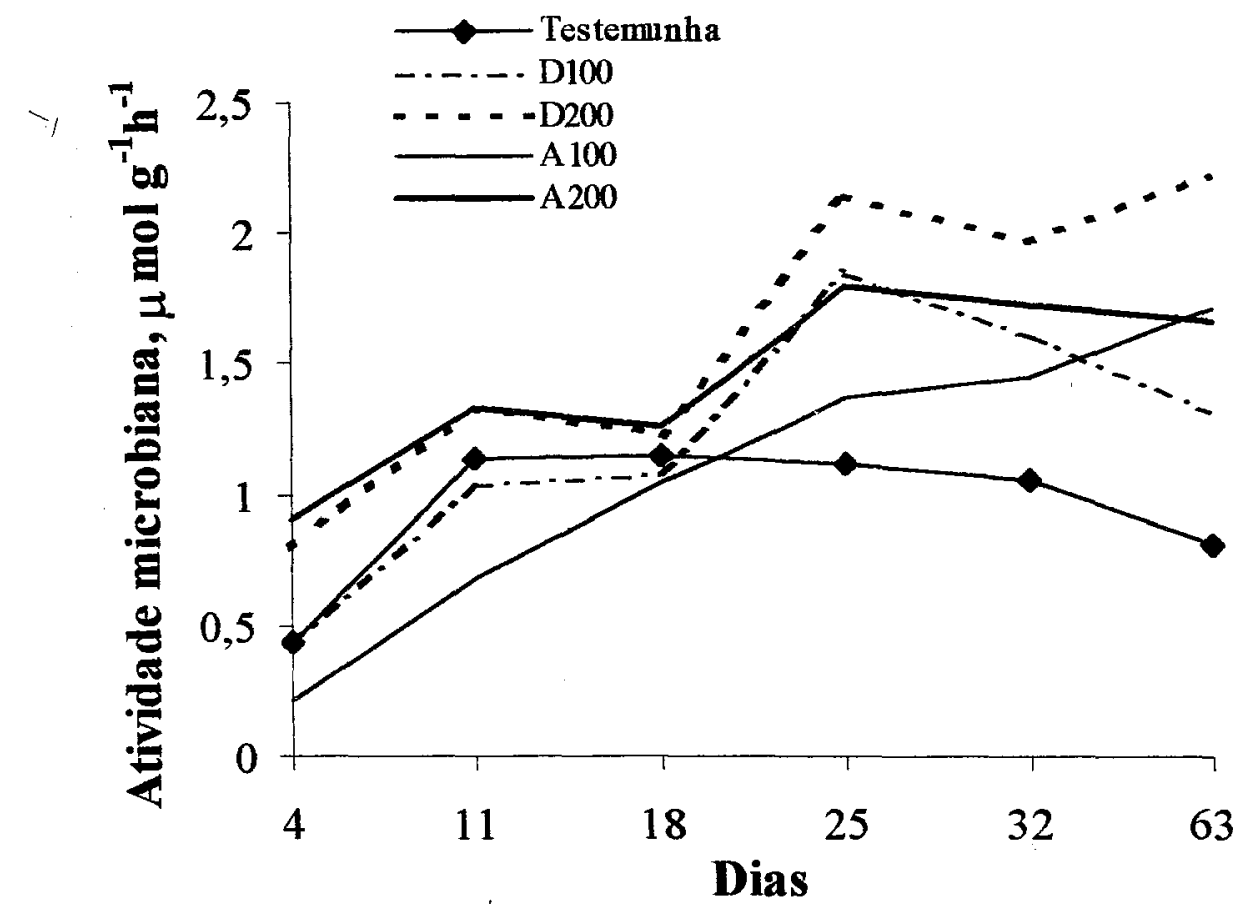

Figura 3. Atividade microbiana no solo Terra Roxa Estruturada tratado com os herbicidas diuron e ametrina e doses de vinhaça de 100 e $200 \mathrm{~m}^{3} \mathrm{ha}^{-1}$. $\left(D 100=\right.$ diuron $+100 \mathrm{~m}^{3} \mathrm{ha}^{-1}$ de vinhaça, D200 $=$ diuron $+200 \mathrm{~m}^{3} \mathrm{ha}^{-1} \mathrm{de}$ vinhaça, $\mathrm{A} 100=$ ametrina $+100 \mathrm{~m}^{3} \mathrm{ha}^{-1}$ de vinhaça, $\mathrm{A} 200=$ ametrina +200 $\mathrm{m}^{3} \mathrm{ha}^{-1}$ de vinhaça)

O aumento da atividade e biomassa microbiana com a adição do resíduo (Figuras 3, 4 e 5) pode ser explicado pelo fornecimento de energia e carbono aos microorganismos quimiorganotróficos através da matéria orgânica da vinhaça, que se constitui numa fonte de carbono solúvel, prontamente disponível. Segundo Rodella et al. (1983), a maior parte do carbono da vinhaça está na forma de glicerol, proveniente de rotas alternativas durante a fermentação na produção do álcool. Já dentro da célula microbiana, o glicerol pode passar a dihidroxicetona que é incorporado a via glicolítica do metabolismo microbiano (Lehninger, 1985).

Outro ponto importante, e bastante discutido na literatura, é o efeito da vinhaça no aumento do $\mathrm{pH}$ do solo, o que também foi observado neste estudo (Figuras 6 e 7). 
Isto pode influenciar diretamente no desenvolvimento de microorganismos responsáveis pela degradação de moléculas de pesticidas.

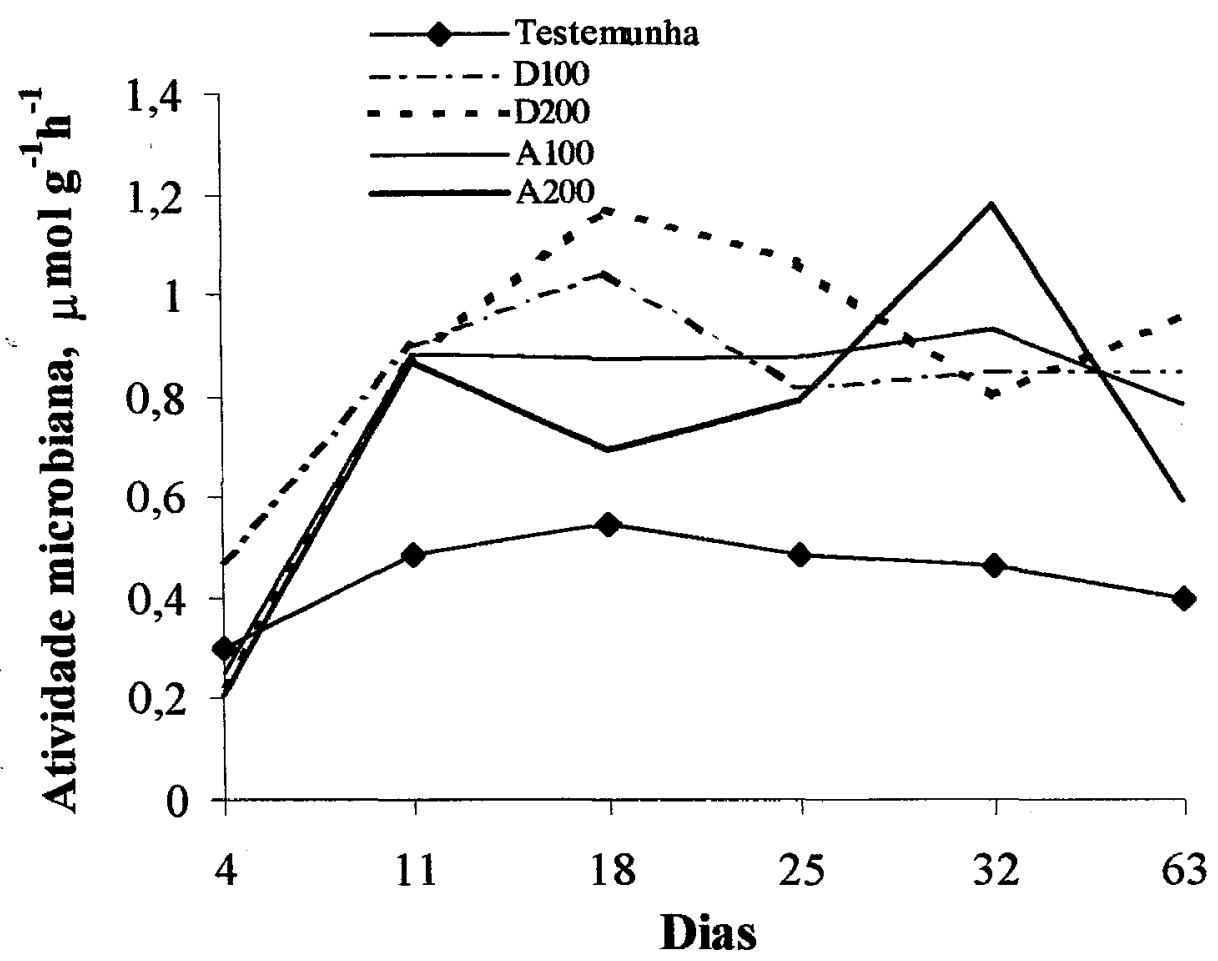

Figura 4. Atividade microbiana no solo Latossolo Vermelho Amarelo tratado com os herbicidas diuron e ametrina e doses de 100 e $200 \mathrm{~m}^{3} \mathrm{ha}^{-1}$ de vinhaça. (D100= diuron $+100 \mathrm{~m}^{3} \mathrm{ha}^{-1}$ de vinhaça, D200 = diuron $+200 \mathrm{~m}^{3} \mathrm{ha}^{-1}$ de vinhaça, $\mathrm{A} 100=$ ametrina $+100 \mathrm{~m}^{3} \mathrm{ha}^{-1}$ de vinhaça, $\mathrm{A200}=$ ametrina $+200 \mathrm{~m}^{3} \mathrm{ha}^{-1} \mathrm{de}$ vinhaça).

Algumas explicações foram sugeridas, em diferentes estudos, buscando o entendimento desta elevação no pH pela adição da vinhaça. Cambium \& Cordeiro (1986) e Camargo et al. (1987) tentaram explicar esta elevação no pH pela introdução de cátions básicos ao sistema, tendo em vista a alta correlação entre o $\mathrm{pH}$ e a saturação por bases encontrada por estes autores. Reis \& Rodella (1998) atribuíram a elevação no pH ao fato de que cerca de $90 \%$ do carbono da vinhaça ser solúvel e assim participar de processos que não ocorrem com as formas sólidas de carbono. Por outro lado, alguns autores defendem que o incremento no $\mathrm{pH}$ pela adição da vinhaça ocorre pelo aumento 
da atividade microbiana do solo, a qual torna o meio redutor (Leal, 1983; Matiazzo \& Glória, 1985). $\mathrm{Na}$ falta de $\mathrm{O}_{2}$, que é o receptor de elétrons, outros receptores seriam utilizados numa escala de potencial de oxi-redução. Estas novas reações seriam consumidoras de prótons, elevando o $\mathrm{pH}$ do meio.

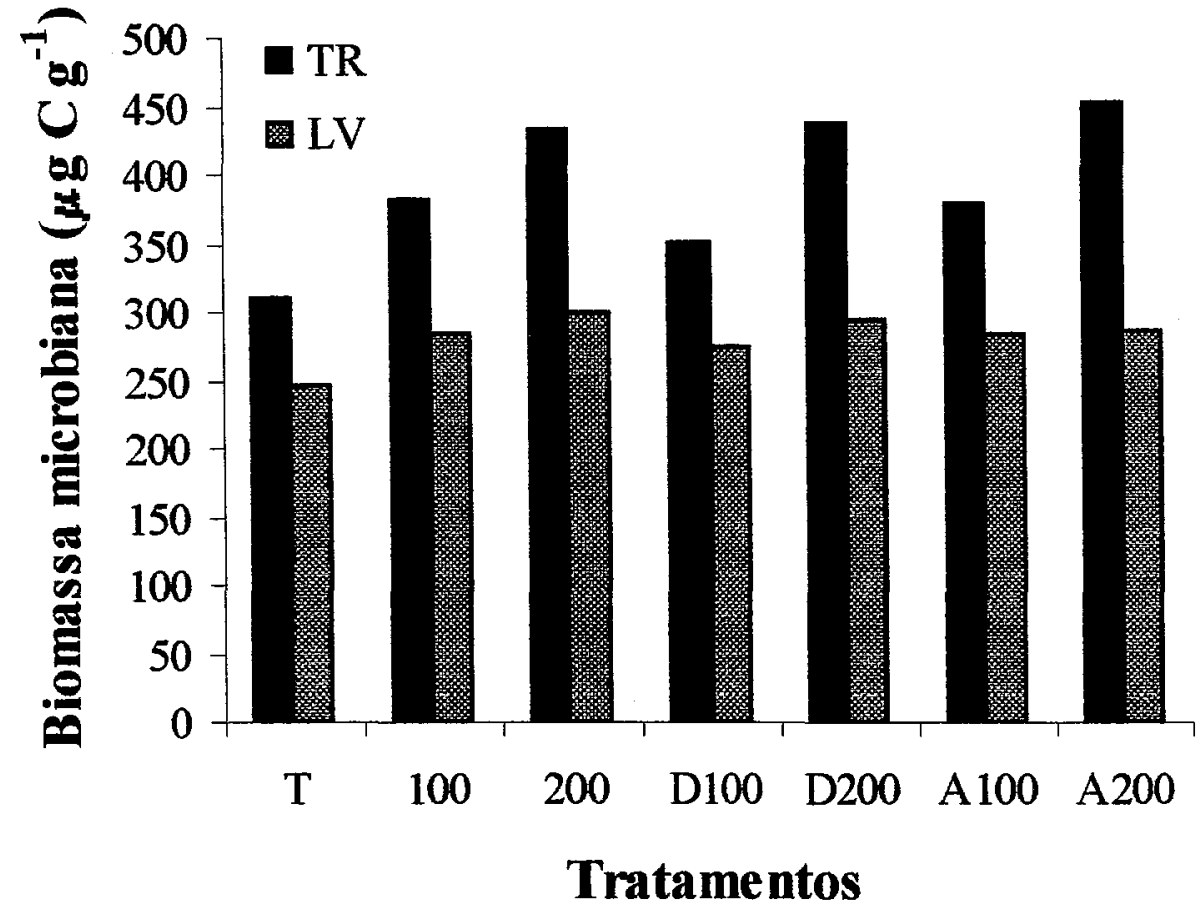

Figura 5. Biomassa microbiana dos solos Terra Roxa Estruturada (TR) e Latossolo Vermelho Amarelo (LV) tratados com os herbicidas diuron e ametrina e incubados com vinhaça. ( $\mathrm{T}=$ testemunha; $100=100 \mathrm{~m}^{3} \mathrm{ha}^{-1}$ de vinhaça; 200 $=200 \mathrm{~m}^{3} \mathrm{ha}^{-1}$ de vinhaça; D100 = Diuron $+100 \mathrm{~m}^{3} \mathrm{ha}^{-1} ; \mathrm{D} 200=$ Diuron + $200 \mathrm{~m}^{3} \mathrm{ha}^{-1} ; \mathrm{A} 100=$ Ametrina $+100 \mathrm{~m}^{3} \mathrm{ha}^{-1} ; \mathrm{A} 200=$ Ametrina $+200 \mathrm{~m}^{3} \mathrm{ha}^{-1}$ )

$\mathrm{O}$ aumento no $\mathrm{pH}$, provocado pela adição da vinhaça ao solo, poderia favorecer o processo de hidroxilação, que é um dos principais processos envolvidos na degradação de pesticidas pelo aumento da polaridade da molécula (Bollag \& Liu, 1990). Isto pode ser uma das possíveis explicações para o aumento da degradação do diuron com a adição da vinhaça, visto que a degradação variou com os aumentos da atividade microbiana, biomassa microbiana e pH no solo Terra Roxa Estruturada. Desta forma, pode ter ocorrido a hidroxilação do radical dimetiluréia do diuron, aumentando a polaridade e, consequentemente, deixando a molécula mais passivel de sofrer os processos de 
degradação. Teoricamente, a hidroxilação também poderia ter ocorrido nos grupos etilamino, isopropilamino e metiltio da ametrina. Cook \& Hütter (1982) observaram uma dessulfuração da ametrina e a formação do metabólito hidroxiametrina, em culturas de bactérias.

No solo TR, o maior despreendimento de ${ }^{14} \mathrm{CO}_{2}$ resultante da aplicação da vinhaça junto ao herbicida diuron, poderia ter ocorrido como consequêencia da atuação indireta de microorganismos. Para a ametrina, esta hipótese também não pode ser descartada. Bollag \& Liu (1990) explicaram estes efeitos indiretos como sendo a transformação do pesticida por reações metabólicas, onde o substrato não serve como fonte de energia aos microorganismos. Eles chamaram este fenômeno de cometabolismo.

Costa (1992), em seus estudos de biodegradação de ametrina com adição de solo rizosférico de cana-de-açúcar, também não descartou a possibilidade de cometabolismo.

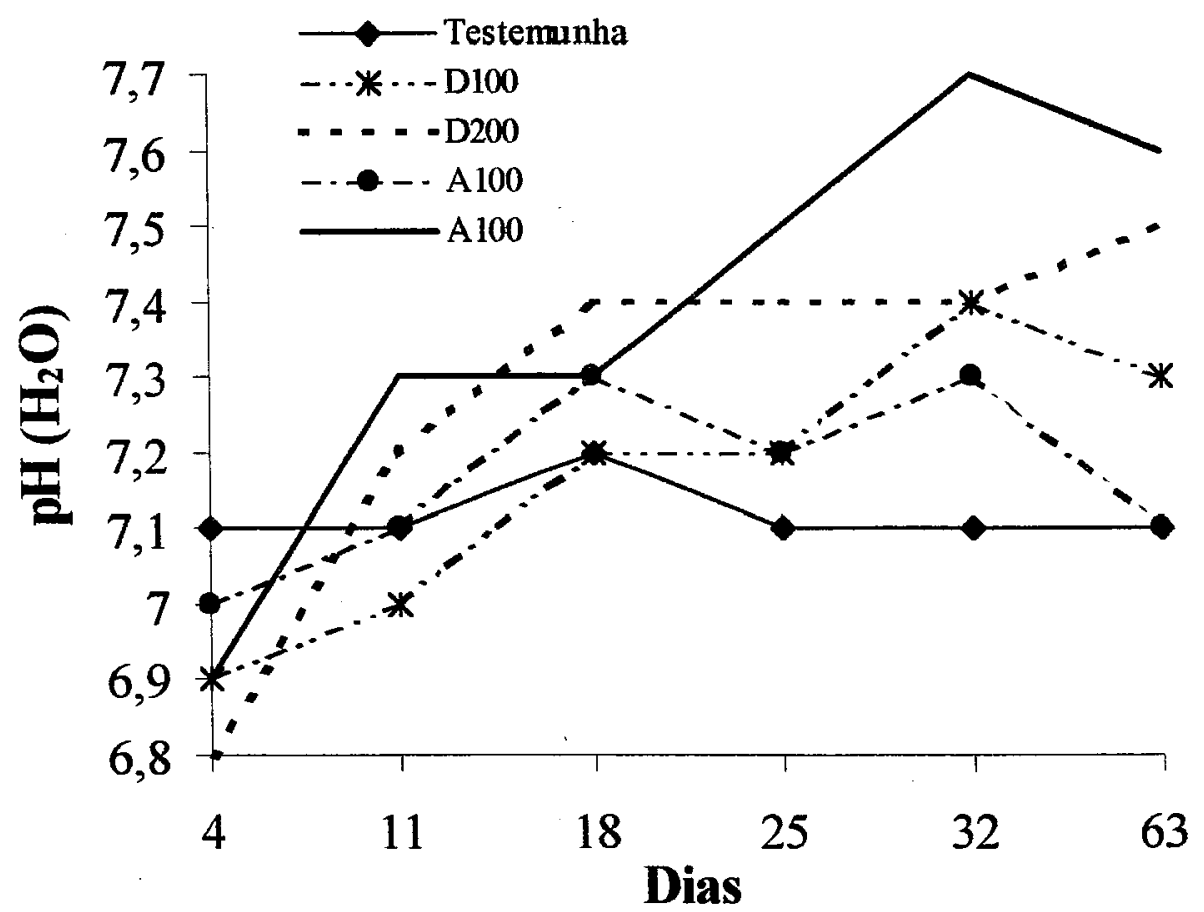

Figura 6. Valores de $\mathrm{pH}_{\mathrm{H} 2 \mathrm{O}}$ no solo Terra Roxa Estruturada, incubado com vinhaça e os herbicidas diuron e ametrina. (D100 $=$ diuron $+100 \mathrm{~m}^{3} \mathrm{ha}^{-1}$ de vinhaça, D200 $=$ diuron $+200 \mathrm{~m}^{3} \mathrm{ha}^{-1}$ de vinhaça, A100 $=$ ametrina $+100 \mathrm{~m}^{3} \mathrm{ha}^{-1}$ de vinhaça, A200 $=$ ametrina $+200 \mathrm{~m}^{3} \mathrm{ha}^{-1}$ de vinhaça) 


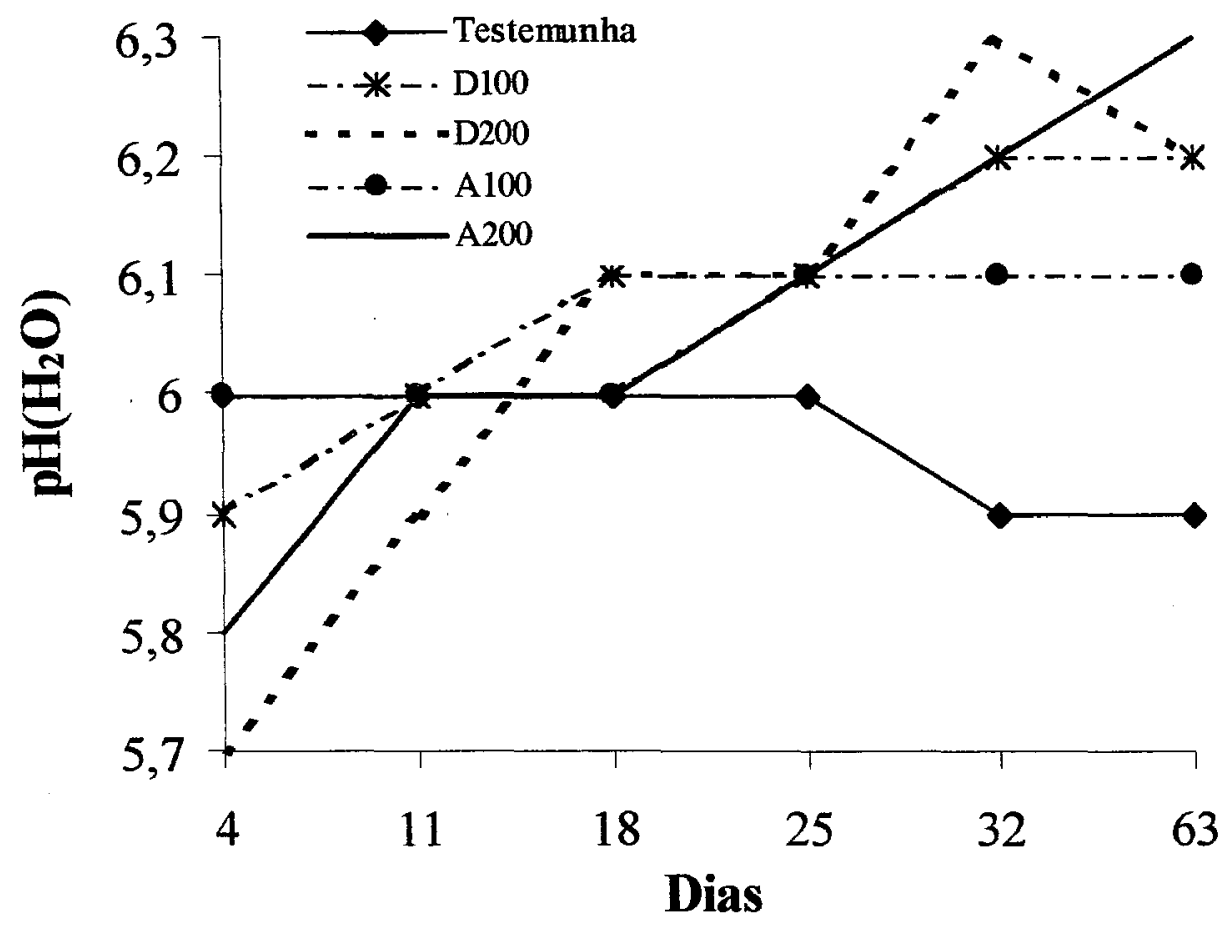

Figura 7. Valores de $\mathrm{pH}_{\mathrm{H} 2 \mathrm{O}}$ no solo Latossolo Vermelho Amarelo incubado com vinhaça e os herbicidas diuron e ametrina. (D100= diuron $+100 \mathrm{~m}^{3} \mathrm{ha}^{-1}$ de vinhaça, D200 $=$ diuron $+200 \mathrm{~m}^{3} \mathrm{ha}^{-1}$ de vinhaça, A100 = ametrina $+100 \mathrm{~m}^{3} \mathrm{ha}^{-1}$ de vinhaça, $\mathrm{A} 200=$ ametrina $+200 \mathrm{~m}^{3}$ ha ${ }^{-1}$ de vinhaça)

Os resultados da percentagem de ${ }^{14} \mathrm{CO}_{2}$ despreendido, resíduo extraível, não extraível e recuperação da radioatividade aplicada na forma de diuron e ametrina, após 120 dias de incubação, encontram-se na Tabela 7.

A recuperação do resíduo extraível do diuron variou de $36,32 \%$, no tratamento onde foi aplicado $200 \mathrm{~m}^{3} \mathrm{ha}^{-1}$ de vinhaça, no solo TR, a 104,1\% onde foi aplicado 200 $\mathrm{m}^{3} \mathrm{ha}^{-1}$ de vinhaça, no LV. Para todos os tratamentos, a extração foi quase a totalidade da fração disponível dos herbicidas (Tabela 7), indicando que estas moléculas não tendem a formação de resíduos ligados. 
Tabela 7. Percentagem de recuperação dos herbicidas diuron e ametrina aos 120 dias após a aplicação nos solos Terra Roxa Estruturada e Latossolo Vermelho Amarelo tratados com 0; 100 e $200 \mathrm{~m}^{3} \mathrm{ha}^{-1}$ de vinhaça. (d.= despreendido; e.= extraído; $n$.= não extraível; r.=recuperado)

\begin{tabular}{|c|c|c|c|c|c|c|c|}
\hline \multirow{3}{*}{${ }^{14} \mathrm{CO}_{2}$} & \multirow{3}{*}{ herbicida } & \multicolumn{3}{|c|}{ Terra Roxa Estruturada } & \multicolumn{3}{|c|}{ Latossolo Vermelho Amarelo } \\
\hline & & \multicolumn{6}{|c|}{ 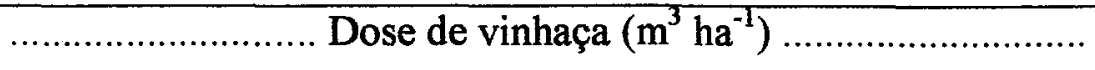 } \\
\hline & & 0 & 100 & 200 & 0 & 100 & 200 \\
\hline d. & diuron & 15,12 & 37,20 & 59,77 & 3,47 & 3,67 & 4,19 \\
\hline e. & & 82,65 & 55,95 & 36,32 & 91,12 & 87,55 & 104,10 \\
\hline $\mathrm{n}$ & & 8,16 & 10,67 & 12,99 & 8,75 & 3,04 & 2,50 \\
\hline r. & & 105,93 & 103,82 & 109,08 & 103,34 & 94,26 & 110,79 \\
\hline d. & ametrina & 24,83 & 28,67 & 22,94 & 0,43 & 7,54 & 1,89 \\
\hline e. & & 69,04 & 65,59 & 71,85 & 94,16 & 103,08 & 89,73 \\
\hline n. & & 14,06 & 10,98 & 4,10 & 1,40 & 3,55 & 3,80 \\
\hline r. & & 107,93 & 105,24 & 98,89 & 95,99 & 114,17 & 95,42 \\
\hline
\end{tabular}

O resíduo não extraível, ou seja, o que persistiu no solo após o processo de extração, variou entre $2,5 \%$ a $12,99 \%$ para o herbicida diuron e entre $1,40 \%$ a $14,06 \%$ para a ametrina. Os valores para o balanço final de recuperação dos herbicidas ficaram entre $94,26 \%$ e $110,79 \%$ para o diuron e entre $95,42 \%$ e $114,17 \%$ para a ametrina.

Os resultados obtidos referentes a produção de metabólitos, após 120 dias de condução do experimento, encontram-se na Tabela 8.

Para o herbicida diuron, no solo TR, foram produzidos os metabólitos com valores de $R_{f}$ de 0,43 e 0,$37 ; 0,16$ e 0,37 ; e 0,37 nas parcelas onde foram aplicadas as doses de vinhaça de 0,100 e $200 \mathrm{~m}^{3} \mathrm{ha}^{-1}$, respectivamente, sendo o valor de $R_{\mathrm{f}} 0,37 \mathrm{o}$ produto original. A identificação dos metabólitos não foi possível pela falta de padrões. No $\mathrm{LV}$ foram encontrados valores de $\mathbf{R}_{\mathrm{f}}$ de 0,31 e 0,37 (produto original), entretanto, nos tratamentos que receberam as maiores doses de vinhaça, uma maior produção de 
metabólitos em relação a molécula original foi constatada, quando analisado o resíduo extraído. Talvez, isto possa ter ocorrido pelo estímulo ao desenvolvimento de determinados grupos de microorganismos que degradam parcialmente esta molécula, ou que atuem somente em alguma das fases de degradação desta, pois os processos de transformação metabólica microbiana de um pesticida envolvem vários mecanismos e vários produtos podem ser formados até a completa mineralização da molécula (Bollag \& Liu, 1990; Alexander, 1994).

Para a ametrina, tanto no solo TR como no $L V$, nas três doses de vinhaça, foi encontrado somente o valor de $R_{f}$ de 0,29 , referente ao produto original. Os altos valores percentuais de concentração desta molécula no solo, reflexo da baixa taxa de degradação, principalmente no solo $\mathrm{LV}$, são indicativos de possíveis problemas ambientais que poderão ser detectados devido ao uso contínuo deste produto.

Resultados semelhantes para a ametrina foram obtidos por Compte (1997), onde não foi observada a formação de metabólitos 63 dias após a instalação do experimento, todavia, o sistema de solventes utilizado foi acetonitrila: água: ácido fórmico (94:5:1, $\mathrm{v} / \mathrm{v} / \mathrm{v})$. Costa (1992), utilizando este mesmo sistema de solventes, encontrou os metabólitos caracterizados pelos valores de $\mathbf{R}_{\mathrm{f}}$ de 0,$11 ; 0,21 ; 0,32 ; 0,51 ; 0,63$ e 0,73 . 
Tabela 8. Identificação da radioatividade extraída, resultante da aplicação dos herbicidas diuron e ametrina nos solos Terra Roxa Estruturada (TR) e Latossolo Vermelho Amarelo (LV) tratados com vinhaça.

\begin{tabular}{|c|c|c|c|c|}
\hline Herbicida & Solo & Doses de vinhaça & $\mathbf{R}_{\mathbf{f}}$ & \% do extraído \\
\hline \multirow[t]{11}{*}{ Diuron } & TR & 0 & 0,43 & 33,64 \\
\hline & & & $0,37^{*}$ & 49,00 \\
\hline & & 100 & 0,16 & 15,16 \\
\hline & & & $0,37^{*}$ & 40,80 \\
\hline & & 200 & $0,37 *$ & 36,32 \\
\hline & LV & 0 & 0,31 & 14,80 \\
\hline & & & $0,37 *$ & 76,32 \\
\hline & & 100 & 0,31 & 20,64 \\
\hline & & & $0,37^{*}$ & 66,92 \\
\hline & & 200 & 0,31 & 29,12 \\
\hline & & & $0,37^{*}$ & 70,88 \\
\hline \multirow[t]{6}{*}{ Ametrina } & TR & 0 & $0,29^{*}$ & 69,04 \\
\hline & & 100 & $0,29 *$ & 65,59 \\
\hline & & 200 & $0,29 *$ & 71,85 \\
\hline & LV & 0 & $0,29 *$ & 94,16 \\
\hline & & 100 & $0,29 *$ & 100,00 \\
\hline & & 200 & $0,29 *$ & 89,73 \\
\hline
\end{tabular}

* Produto original

\subsection{Adsorção}

Os valores de $\mathrm{K}_{\mathrm{f}}$ obtidos para o herbicida diuron, em ambos os solos, praticamente não foram alterados com a adição da vinhaça (Tabela 9). Todavia, esta molécula foi mais adsorvida pelo solo TR do que pelo LV, como pode ser observado nas 
isotermas de adsorção (Figura 8) e também pelas constantes de Freundlich mostradas na Tabela 9.

A

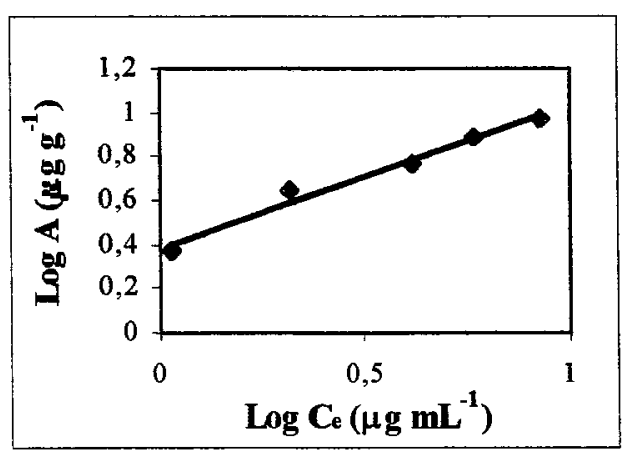

$\mathrm{C}$

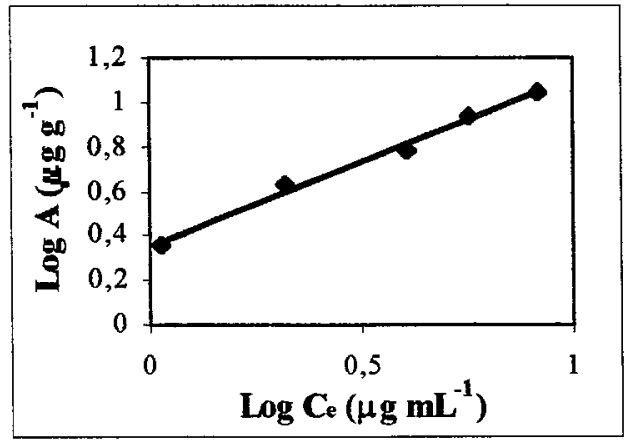

$\mathrm{E}$

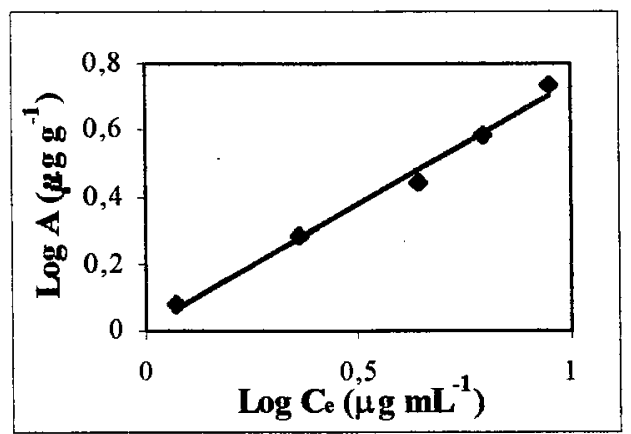

B

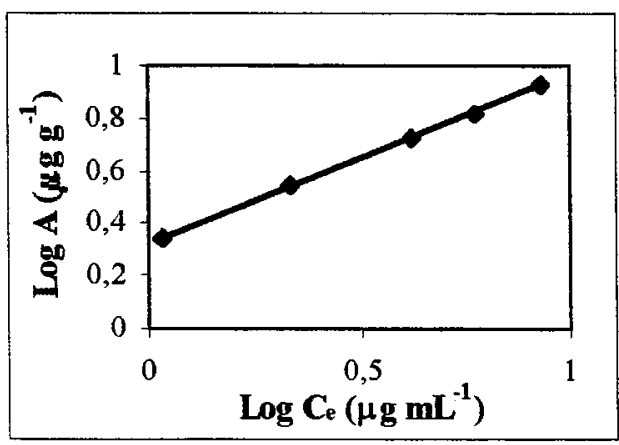

$\mathrm{D}$
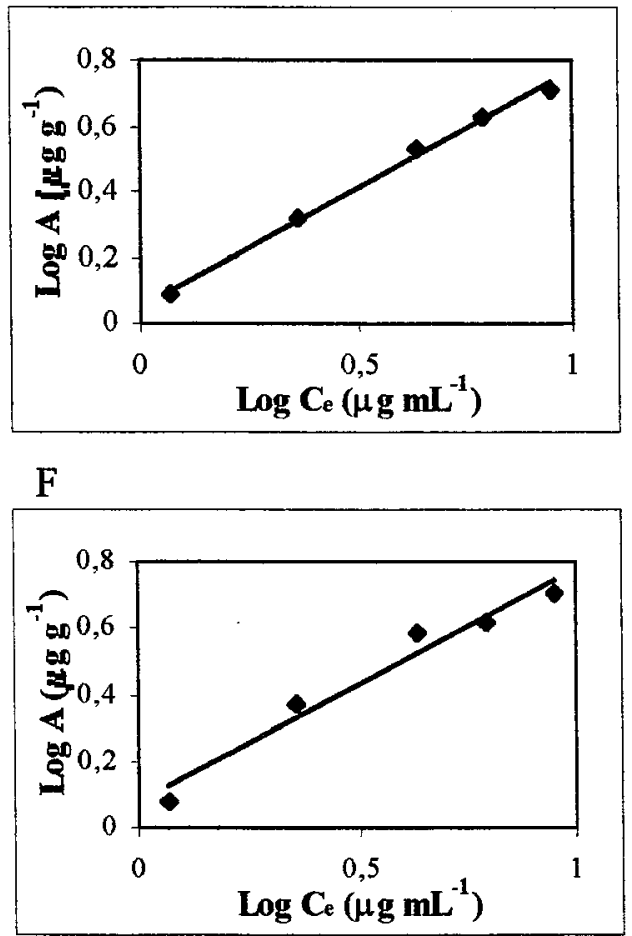

Figura 8. Isotermas de adsorção do herbicida diuron para os solos da classe Terra Roxa Estruturada (TR) e Latossolo Vermelho Amarelo (LV) tratados com as doses de vinhaça de $0 ; 100$ e $200 \mathrm{~m}^{3} \mathrm{ha}^{-1}$ (A: TR sem vinhaça; B: TR x $100 \mathrm{~m}^{3} \mathrm{ha}^{-1}$; C: TR x $200 \mathrm{~m}^{3} \mathrm{ha}^{-1}$; D: LV sem vinhaça; E: LV x $100 \mathrm{~m}^{3} \mathrm{ha}^{-1}$; F: LV x 200 $\mathrm{m}^{3} \mathrm{ha}^{-1}$ ) 
Tabela 9. Parâmetros de Freundlich para a capacidade de adsorção dos herbicidas diuron e ametrina nos solos da classe Terra Roxa Estruturada e Latossolo Vermelho Amarelo tratados com as doses de vinhaça de $0 ; 100$ e $200 \mathrm{~m}^{3} \mathrm{ha}^{-1}$.

\begin{tabular}{|c|c|c|c|c|}
\hline \multirow[t]{2}{*}{ Solos } & \multirow[t]{2}{*}{ Doses de vinhaça $\left(\mathrm{m}^{3} \mathrm{ha}^{-1}\right)$} & \multicolumn{2}{|c|}{ Parâmetros de Freundlich $^{\text {a/ }}$} & \multirow[b]{2}{*}{$R^{2 d /}$} \\
\hline & & $\mathbf{K}_{\mathbf{f}} \mathbf{b}^{\prime}$ & $1 / n^{c /}$ & \\
\hline & & & Diuron & \\
\hline \multirow[t]{3}{*}{ TR } & 0 & 2,4 & 0,64 & 0,97 \\
\hline & 100 & 2,1 & 0,64 & 0,99 \\
\hline & 200 & 2,3 & 0,75 & 0,99 \\
\hline \multirow[t]{4}{*}{ LV } & 0 & 1,1 & 0,72 & 0,99 \\
\hline & 100 & 1,0 & 0,72 & 0,98 \\
\hline & 200 & 1,2 & 0,69 & 0,98 \\
\hline & & & Ametrina & \\
\hline \multirow[t]{3}{*}{ TR } & 0 & 2,7 & 0,46 & 0,98 \\
\hline & 100 & 2,9 & 0,49 & 0,98 \\
\hline & 200 & 2,2 & 0,61 & 0,98 \\
\hline \multirow[t]{3}{*}{ LV } & 0 & 1,6 & 0,51 & 0,96 \\
\hline & 100 & 1,6 & 0,52 & 0,88 \\
\hline & 200 & 1,2 & 0,65 & 0,99 \\
\hline \multicolumn{5}{|c|}{ a/ obtidos pela equação 3 . } \\
\hline \multicolumn{5}{|c|}{ b/ constante de Freundlich } \\
\hline ef grau de & nearidade das isotermas de ac & rção & & \\
\hline
\end{tabular}

O diuron é uma molécula pertencente ao grupo das não iônicas e apresenta valores de solubilidade em água de $62 \mathrm{mg} \mathrm{L}^{-1}$ e $\log \mathrm{K}_{\text {ow }}$ de 2,85 (Luchini, 1987), o que a confere características hidrofóbicas e justifica os maiores valores de $\mathrm{K}_{\mathrm{f}}$ no solo com teor de matéria orgânica mais elevado (TR). Resultados semelhantes foram obtidos por Grover (1975), Luchini, (1987) e Gaillardon (1997). Isto indica que, provavelmente, a interação hidrofóbica do pesticida com a matéria orgânica do solo pode estar ocorrendo, 
entretanto, Stevenson (1972) sugeriu que o mecanismo de adsorção de compostos orgânicos não iônicos se dá por ligações de pontes de hidrogênio entre o herbicida e o adsorvato.

O solo TR também apresenta maior percentual de argila e CTC mais elevada que o LV. Mustafa \& Gamar (1972) obtiveram significativos coeficientes de correlação entre o diuron adsorvido e a capacidade de troca de cátions, superfície específica e, em menor escala, percentagem de argila em solos de regiões áridas do Sudão com baixa quantidade de matéria orgânica.

Constantes de Freundlich de 1,94 a 23,15 foram encontrados por Luchini (1987) para a adsorção do diuron, sendo estas maiores nos solos com taxas de matéria orgânica mais elevadas. Graus de linearidade das isotermas, neste mesmo trabalho, ficaram entre 0,79 e 1,07. Valores de $K_{f}$ condizentes aos mostrados na Tabela 9, também foram encontrados por Gaillardon (1997) e Walker \& Jurado-Exposito (1998), entretanto, os valores de $1 / n$ foram sempre superiores aos mostrados na mesma tabela.

Para o herbicida ametrina, as doses de vinhaça também não contribuíram para o aumento do processo de adsorção nos dois solos estudados, como pode ser observado na Figura 9 e confirmado pelos valores de $\mathbf{K}_{\mathbf{f}}$ mostrados na Tabela $9 \mathrm{e}$, da mesma forma que o diuron, este pesticida foi mais adsorvido no TR do que no LV (Figura 9).

A ametrina é uma molécula herbicida de caráter básico, sendo assim doadora de prótons, apresentando um $\mathrm{pK}_{\mathrm{a}}$ em torno de 4,0 (Weber, 1970). Isto sugere que sua adsorção pelos colóides do solo seja aumentada com o decréscimo do $\mathrm{pH}$ da solução. Porém, neste caso, o $\mathrm{pH}$ dos solos está acima do $\mathrm{pK}_{\mathrm{a}}$ do produto em mais de duas unidades, isto é, praticamente toda a ametrina encontra-se na fase molecular, o que implica que, provavelmente, a adsorção da molécula não está ocorrendo pela ação de forças eletrostáticas. 
G

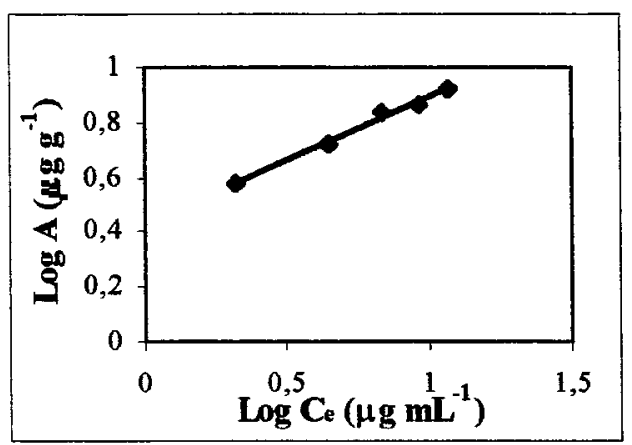

I

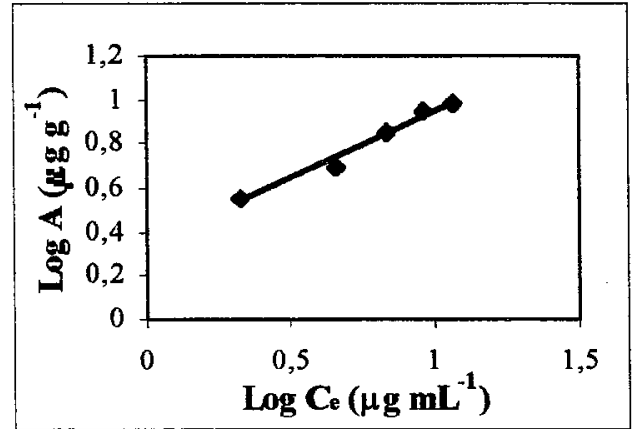

$\mathrm{K}$

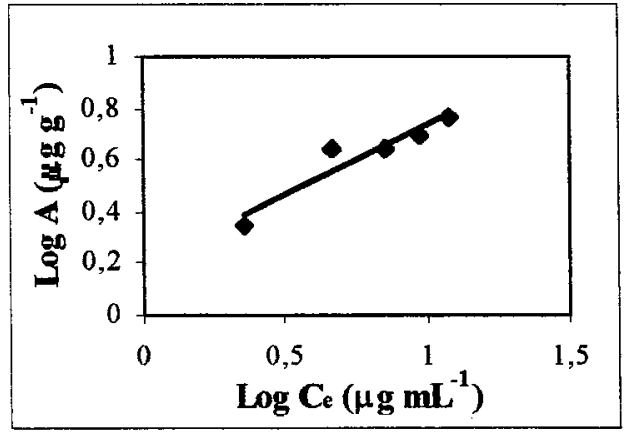

$\mathrm{H}$

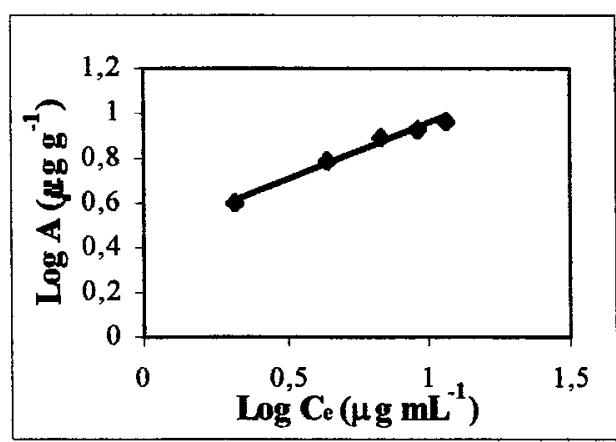

J

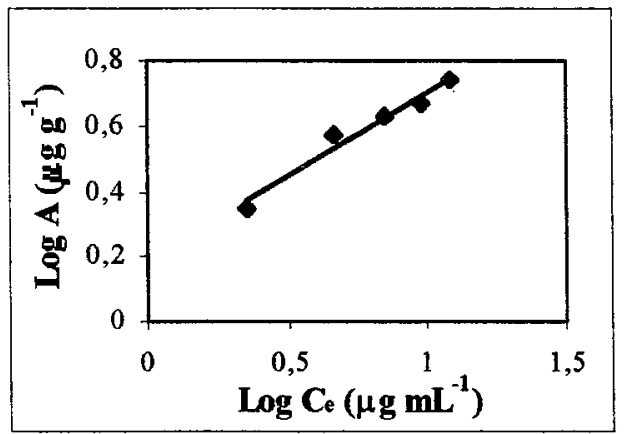

$\mathrm{L}$

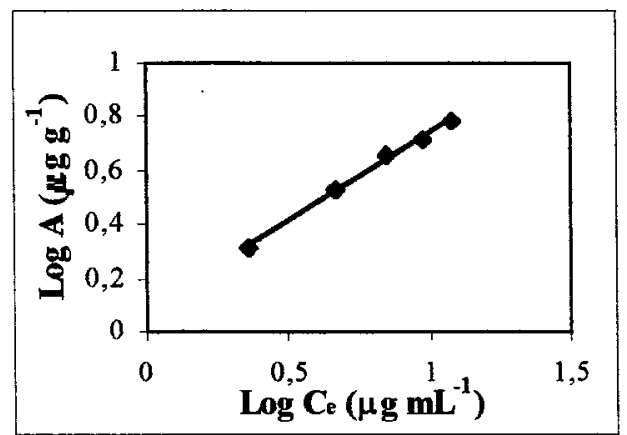

Figura 9. Isotermas de adsorção do herbicida ametrina para os solos da classe Terra Roxa Estruturada (TR) e Latossolo Vermelho Amarelo (LV) tratados com as doses de vinhaça de $0 ; 100$ e $200 \mathrm{~m}^{3} \mathrm{ha}^{-1}$ (G: TR sem vinhaça; H: TR x 100 $\mathrm{m}^{3} \mathrm{ha}^{-1}$; I: TR x $200 \mathrm{~m}^{3} \mathrm{ha}^{-1}$; J: LV sem vinhaça; K: LV x $100 \mathrm{~m}^{3} \mathrm{ha}^{-1}$; L: LV $\mathrm{x} 200 \mathrm{~m}^{3} \mathrm{ha}^{-1}$ ) 
Os valores de $\mathrm{K}_{\mathrm{f}}$ obtidos para a adsorção da ametrina encontram-se na Tabela 9 e são condizentes aos encontrados por Yamane \& Green (1972) e Furlan (1992), que variaram de 1,84 a 15,77 para solos com $\mathrm{pH}$ em $\mathrm{H}_{2} \mathrm{O}$ entre 4,8 e 6,5, respectivamente. Os valores de $1 / \mathrm{n}$ (Tabela 9) também são condizentes com os obtidos por Furlan (1992).

A não interferência da adição da vinhaça no processo de adsorção dos herbicidas diuron e ametrina pode ser explicada, provavelmente, pelo fato da matéria orgânica deste resíduo ser constituída, principalmente, de glicerol, que é prontamente disponível aos microorganismos quimiorganotróficos do solo, como já foi discutido no ítem 4.1. Assim, após 4 dias da adição da vinhaça, período após o qual foi realizada a aplicação dos herbicidas, grande parte da matéria orgânica do resíduo já havia sido mineralizada. Isto pode ser observado pelas análises de C orgânico (Tabela 10) das amostras de solo com e sem adição de vinhaça, 4 dias após sua aplicação.

Tabela 10. Carbono orgânico em solos da classe Terra Roxa Estruturada (TR) e Latossolo Vermelho Amarelo (LV) 4 dias após a aplicação da vinhaça.

\begin{tabular}{|c|c|c|}
\hline \multirow[b]{2}{*}{ Dose de vinhaça } & \multicolumn{2}{|c|}{ Solo } \\
\hline & Terra Roxa Estruturada & Latossolo Vermelho Amarelo \\
\hline $\mathrm{m}^{3} \mathrm{ha}^{-1}$ & ….......................... & $\mathrm{kg}^{-1}$ \\
\hline 0 & $14,8 *$ & 4,6 \\
\hline 100 & 15,1 & 4,7 \\
\hline 200 & 14,5 & 4,9 \\
\hline
\end{tabular}

* Médias de duas repetições. O maior coeficiente de variação foi de $6,95 \%$ para o TR e $13,86 \%$ para 0 LV. 


\section{CONCLUSÕES}

A adição de vinhaça ao solo não interfere na adsorção de pesticidas, pelo fato de seu carbono ser prontamente disponivel aos microorganismos e, desta forma, contribuir com a biodegradação destas moléculas, desde que existam no solo espécies que as degradem, podendo até provocar uma alteração na classificação quanto a persistência do produto feita pelo IBAMA.

Os herbicidas estudados foram pouco adsorvidos pelo solo e puderam ser extraídos 120 dias após a aplicação, o que indica uma baixa tendência a formação de resíduos ligados. Entretanto, a baixa degradação da ametrina pode ser preocupante merecendo mais atenção em estudos de bioquímica ambiental.

O cometabolismo pode ser um dos processos envolvidos na transformação microbiana do diuron e da ametrina. 


\section{REFERÊNCIAS BIBLIOGRÁFICAS}

ALEXANDER, M. Biodegradation and bioremediation. New York: Academic Press, 1994. 302p.

ALMEIDA, J.R.; RANZANI, G.; VALSECHI, O. La vinasse dans l'agriculture. Piracicaba: Instituto Zimotécnico, 1950. v.1, 21p.

ALMEIDA, J.R. O problema da vinhaça em São Paulo. Piracicaba: Instituto Zimotécnico, 1952. v.3, 9p.

ALMEIDA, J.R. Interferência dos fungos na adubação do solo pela vinhaça. Piracicaba: Instituto Zimotécnico, 1953. v.5, 10p.

ANDERSON, J.P.E. Principles of an assay systems for biodegradation. Advances in Applied Biotechnology, v.4, p.129-145, 1990.

ATTAWAY, N.D.; CAMPER, N.D.; PAYNTER, M.L.B. Anaerobic microbial degradation of diuron by pond sediment. Pesticide Biochemistry Physiology, v.17, p.96-101, 1982.

BAILEY, G.W; WHITE, J.L. Factors influencing the adsorption and movement of pesticides in soils. In: GUNTHER, F.A.; GUNTHER, J.D. (Ed.) Residue reviews. New York: Spriger-Verlag, 1970. p.29-92.

BARBA, R.C.; ROMANOVSKI, R.R. Differential phytotoxicity of atrazine and ametryne to bananas. Weed Research, v.9, p.114-121, 1969. 
BARRIUSO, E.; FELLER, C.; CALVET, R.; CERRI, C.C. Sorption of atrazine, terbutryn and 2,4-D herbicides in two Brasilian Oxisols. Geoderma, v.53, p.155$162,1992$.

BLANCO, H.G.; NOVO, M.C.S.S.; OLIVEIRA, D.A. Atividade residual de herbicidas em solos argilosos na cultura de cana-de-açúcar (Saccharum $s p$ ): dados de três anos: In: CONGRESSO BRASILEIRO DE HERBICIDAS E ERVAS DANINHAS, 14, Campinas, 1982. Resumo. Campinas: SBHED, 1982. p.24-25.

BOLLAG, J.M.; LIU, S.Y. Biological transformation processes of pesticides. In: CHENG, H.H. (Ed.) Pesticides in the soil environment: processes, impacts and modeling. Madison: Soil Science Society of America, 1990. p.169-211.

BUSS, A; GLÓRIA, N.A. da; JACINTO, O.A. Viabilidade do uso de herbicidas em mistura com vinhaça para o controle de plantas daninhas em soqueiras de cana-deaçúcar. Planta daninha, v.2, p.49-56, 1978.

CALERO, B.J.; ARCIA, F.J.; CHANG, I. Persistência de la ametrina y la atrazina en un suelo Oscuro Plástico Gleyzoso. Ciencias de la Agricultura, v.21, p.105-111, 1984.

CAMARGO, O A de; VALADARES, J.M.A.S.; GERALDI, R.N. Características químicas e físicas de um solo que recebeu vinhaça por longo tempo. Engenharia, n.445, p.8-19, 1984.

CAMARGO, O.A.; VALADARES, J.M.A.S.; BERTON, R.S.; TEÓFILO SOBRINHO, J.; MENK, J.R.F. Alteração de características químicas de um Latossolo Vermelho-Escuro distrófico pela aplicação de vinhaça. Campinas: IAC, 1987. 23p. (IAC. Boletim Científico, 9). 
CAMBUIM, F.A ; CORDEIRO, D.A. Ação da vinhaça sobre $\mathrm{pH}$, acidez total, acumulação e lixiviação de nutrientes, em solo arenoso. Stab Açúcar e Álcool e Subprodutos, v.4, n.4, p.27-33, 1986.

CASTRO, T.F.; YOSHIDA, T. Effect of organic matter on the biodegradation of some organochlorine insecticides in submerged soils. Soil Science and Plant Nutrition, v.20, p.363-370, 1974.

CHAPMAN, R.A.; HARRIS, C.R. Persistence chlorospyrites in a mineral and organic soil. Journal of Environmental Science and Health, v.15, p.39-46, 1980.

COMPTE, V.X. Avaliação de metodologias de coleta de ${ }^{14} \mathrm{CO}_{2}$ em estudos de biodegradação de agroquímicos em solos. Piracicaba, 1997. 55p. Dissertação (Mestrado) - Centro de Energia Nuclear na Agricultura, Universidade de São Paulo.

COOK, A. M.; HÜTTER, R. Ametryne and prometryne as sulfur sources for bacteria. Applied Environmental Microbiology, v.43, p.781-786, 1982.

COSTA, M.P. Efeito da matéria orgânica em alguns atributos do solo. Piracicaba, 1983, 137p. Dissertação (Mestrado) - Escola Superior de Agricultura "Luiz de Queiroz", Universidade de São Paulo.

COX, L.; WALKER, A.; WELCH, S.J. Evidence for the accelerated degradation of isoproturon in soils. Pesticide Science, v.48, p.253-260, 1996.

FAY, E.F.; SILVA, M.M.S.S.; MELO, I.S. Degradação abiótica de xenobióticos. In: MELO, I.S.; AZEVEDO, J.L. (Ed.) Microbiologia ambiental. Jaguariuna:EMBRAPA, CNPMA, 1998, p.125-140. 
FELSOT, A. S.; DZANTOR, E. K. Enhancing biodegradation for detoxification of herbicide waste in soil. In: RACKE, K. D.; COATS, J. R. (Ed.) Enhanced biodegradation of pesticides in the environment. Washington: ACS, 1990. p.6881.

FERREIRA, W.A. Efeito da vinhaça em solos de diferentes texturas. Piracicaba, 1980. 67p. Dissertação (Mestrado) - Escola Superior de Agricultura "Luiz de Queiroz", Universidade de São Paulo.

FREITAS, J.R.; NASCIMENTO FILHO, V.F.; VOSE, P.B.; RUSCHEL, A.P. Estimativa da atividade da microflora heterotrófica do solo TRE usando respirometria com Glicose- ${ }^{14}$ C. Energia Nuclear e Agricultura, v.1, n.2, p. 123130, 1979.

FURLAN, G.R. Efeito da queimada na adsorção, dessorção e mobilidade dos herbicidas 2,4-D, ametrina e trifluralina em dois solos da região mazônica. Piracicaba, 1992. 53p. Dissertação (Mestrado) - Centro de Energia Nuclear na Agricultura, Universidade de São Paulo.

GAILLARDON, P. Influence of soil moisture on long-term sorption of diuron and isoproturon by soil. Pesticide Science, v.47, p:347-354, 1996.

GAILLARDON, P.; FAUCONNET, F.; JAMET, P.; SOULAS, G.; CALVET, R. Study of diuron in soil solutions by means of a novel simple technique using glass microfibre filters. Weed Research, v.31, p.357-366, 1991.

GAILLARDON, P. Desorption of diuron and isoproturon from undispersed clay loam soill. Pesticide Science, v.51, p. 185-193, 1997. 
GLÓRIA, N. A. da.; MAGRO, J. A. Utilização agrícola de resíduos da usina de açúcar na Usina da Pedra. In: SEMINÁRIO COPERSUCAR DA AGROINDÚSTRIA AÇUCAREIRA, 4, Águas de Lindóia, 1976. Anais. Águas de Lindóia: COPERSUCAR, 1976. p.163-180.

GROVER, R. Adsorption and desorption of urea herbicides on soils. Canadian Journal of Soil Science, v.55, n.2, p.127-135, 1975.

HELLING, C. Pesticide mobility in soils. Soil Science Society of America Proceedings, v.35, n.5, p.732-748, 1971.

HILL, G.D.; Mc GAHEN, J.W.; BAKER, H.; FINNERTY, D.W.; BINGERMAN, C.W. The fate of substituted urea herbicides in agricultural soils, Agronomy Journal, v.47, p.93-104.

KEARNEY, P.C.; KAUFMAN, D.D.; ALEXANDER, M. Biochemistry of herbicide decomposition in soil. In: Mc LAREN, A.D.; PETERSON, G.H. (Ed.) Soil biology and biochemistry. Oxford, 1967, p.318-340.

LAVORENTI, A. Comportamento dos herbicidas no meio ambiente. In: WORKSHOP SOBRE BIODEGRADAÇÃO. Campinas, 1996. Anais. Jaguariuna: EMBRAPA, CNPMA, 1996. p.81-115.

LAVORENTI, A. Identificação de perigos de resíduos ligados de pesticidas em substâncias húmicas. In: ENCONTRO BRASILEIRO DE SUBSTÂNCIAS HÚMICAS, 2, São Carlos, 1997. Anais. São Carlos:EMBRAPA, 1997. p.66-71.

LEAL, J.R.; AMARAL SOBRINHO, N.M.B.; VELLOSO, A.C.X.; ROSSIELLO, R.O.P. Potencial redox e pH: variações em um solo tratado com vinhaça. Revista Brasileira de Ciências do Solo, v.7, n.3, p.257-261, 1983. 
LEHNINGER, A. L. Princípios de bioquímica. Trad. de W.L. Lodi e A.A. Simões. São Paulo: Sarvier, 1985. 725p.

LEON, L.; MANUEL, C.; BORNEMISZA, E. Residuos, degradación y comportamiento de la ametrina en un vertisol de Guanacaste, Costa Rica. Turrialba, v.28, n.1, p.3-7, 1978.

LIMA, I. T. Efeitos da aplicação de vinhaça sobre a microflora do solo. Rio de Janeiro, 1980. 100p. Dissertação (Mestrado) - Universidade Federal Rural do Rio de Janeiro.

LIU, L.C.; CIBES-VIADÉ, H. Effect of various herbicides on the respiration of soil microorganisms. The Journal of the University of Puerto Rico, v.56, n.4, p.17, 1972.

LIU, L.C.; CIBES-VIADE, H.; KOO, F.K.S. Adsorption of ametryne and diuron by soils. Weed Science, v.18, n.4, p.470-474, 1970.

LUCHINI, L.C. Adsorção-dessorção dos herbicidas paraquat, diuron e 2,4-D em seis solos brasileiros. Piracicaba-SP, 1987. 91p. Dissertação (Mestrado) - Escola Superior de Agricultura "Luiz de Queiroz", Universidade de São Paulo.

MARTINEZ CRUZ, A.; ALEMÉN, I.; BACH, T.; CALERO, B.J. Effects of irrigation with sugar factory waste water. II. Microflora associated to the carbon cicle. Ciencias de la Agricultura, v.30, p.118-127, 1987.

MATTIAZZO, M.E.; GLÓRIA, N.A. Effect of vinasse on soil activity. Water Science and Tecnology, v.19, p.1293-1296, 1987. 
MEDEIROS, A.P. Composição química dos diferentes tipos de vinhaça nos Estados de Pernambuco, Paraíba e Rio Grande do Norte. . Stab Açúcar e Álcool e Subprodutos, v.4, n.12, p.36-40, 1981.

MESQUTTA. T.B.; RUEGG, E.F. Influência de agentes tensoativos na deteç̧ão da radiação beta. Ciência e Cultura, v.36, p.446-450, 1984.

MINHONI, M.T.A.; CERRI, C.C. Decomposição de vinhaça em solo sob diferentes níveis de umidade: liberação de $\mathrm{CO}_{2}$, formação de biomassa microbiana e imobilização do nitrogênio adicionado. Revista Brasileira de Ciências do solo, v.11, p.25-30, 1987.

MONTEIRO, R.T. Biodegradação de pesticidas. In: WORKSHOP SOBRE BIODEGRADAÇÃO, Campinas, 1996. Anais. Jaguariuna: EMBRAPA, CNPMA, 1996. p.120-128.

MONTEIRO, R. T. Degradação de pesticidas. In: MELO, I. S. e AZEVEDO, J. L. (Ed.) Microbiologia ambiental. Jaguariuna: EMBRAPA, CNPMA, 1998. p.107-124.

MijSTAFA, M.A.; GAMAR, Y. Adsorption and desorption of diuron as a function of soil properties. Soil Science Society Proceedings, v.36, p.561-565, 1972.

MUSUMECI, M.R.; RUEGG, E.F. Degradação microbiana do fungicida metalaxil no solo. Fitopatologia Brasileira, v.9, p.583-591, 1984.

PECK, D.E.; CORWIN, D.L.; FARMER, W.J. Adsorption-desorption of diuron by freschwater sediments. Journal of Environmental Quality, v.9, n.1, p.101-106, 1980. 
REGITANO, J.B. Sorption and Kinetics of imazaquin in surface soils. Purdue, 1994. Thesis of Doctor of Philosophy, Purdue Univesity.

REIS, T.; RODELLA, A.A. Relação entre a incorporação de matéria orgânica, pH e alumínio trocável do solo. In: REUNIÃO BRASILEIRA DE FERTILIDADE DO SOLO, 22ª . Caxambú, 1998. Anais. Caxambú:SBCS, 1998. p382.

REZENDE, J.O. Consequências da aplicação de vinhaça sobre algumas propriedades fisicas de um solo Aluvial: estudo de um caso. Piracicaba, 1979. Tese (Doutorado)Escola Superior de Agricultura "Luiz de Queiroz", Universidade de São Paulo.

RIBEIRO, A C.; SENGIK, E. Efeitos da aplicação de vinhaça nas propriedades fisicas e químicas de duas amostras de Latossolos. Revista Ceres, v. 30, p.25-31, 1983.

RODELLA A.A; PARAZZI, C. Composição de vinhaça de destilarias autônomas. Brasil Açucareiro, v.96, n.4, p.25-28, 1980.

RODELLA, A.A.; ZAMBELLO JÚNIOR, E.; ORLANDO FILHO, J. Effects of vinasse added to soil on $\mathrm{pH}$ and exchangeable aluminum content. In: CONGRESS OF INTERNATIONAL SOCIETY OF SUGAR CANE TECHNOLOGISTS, $18^{\circ}$. La Habana, 1983. Proceedings, 1983. p.189-214.

RODRIGUES, B.N.; ALMEIDA, F.S. de. Guia de herbicidas, Londrina:IAPAR. 1995. 675p.

RODRIGUES, J.J.V. Comportamento dos herbicidas no solo. Informe Agropecuário de Belo Horizonte, v.11, n. 129, p.39-43, 1985. 
ROSS, P.; FROBERVILLE, L.F. de. Disposal of waste waters. Proceedings of the Annual Meeting Congress. South African Sugar Technologists Association, 1928. p. 35-42.

SHEETS, T.J. Reviews of desappeanrance of substituted urea herbicides from soil, Journal of the Agricultural and Food Chemistry, v.12, p.30-33, 1964.

STEVENSON, F.J. Organic matter reactions involving herbicides in soil. Journal of Environmental Quality, v.1, n.4, p.333-343, 1972

TAN, K.H. Priciples of soil chemistry. 2. ed. New York, Basel, Hong Kong. 1993. $362 p$.

VALSECHI, O; GOMES, F.P. Solos incorporados de vinhaça e seu teor de bases. Separatas de Anais da Escola Superior de Agricultura "Luiz de Queiroz", n.11, p.135-158, 1954.

VANCE, E.D.; BROOKES, P.C.; JENKINSON, D.S. An extraction method for measuring soil microbial biomass C. Soil Biology and Biochemistry, v.19, p.703$707,1987$.

VITTI, G.C.; LUZ, P.H.C. Calagem e uso do gesso agrícola em pastagens. In: SIMPÓSIO SOBRE ECOSSISTEMA DE PASTAGENS, 3, Jaboticabal, 1997. Anais. Jaboticabal: UNESP, FCAV, 1997. 341p.

VROUMSIA, T.; STEIMAN, R.; SEIGLE-MURANDI, F.; BENOIT-GUYOD, J.L.; KHADRANI, A. Biodegradation of three substitued phenylurea herbicides (chlortoluron, diuron and isoproturon) by soil fungy. A comparative study. Chemosphere, v.33, n.10, p.2045-2056, 1996. 
WALKER, A.; JURADO-EXPOSITO, M. Adsorption of isoproturon, diuron and metsulfuron-methyl in two soils at high soil:solution ratios. Weed Research, v.38, n.3, p.229-238.

WEBER, J.B. Mechanisms of adsorption of s-triazines by clay colloids and factors affecting plant availability. Research Review, v.32, p.93-130, 1970.

WEBER, J. B. Interaction of organic pesticides with particular matter in aquatic and soil systems. Advances in Chemistry Series. p.55-120, 1972.

WEED, S.B.; WEBER, J.B. Pesticides organic matter interactions. In: GUENZI, W.D., (Ed.) Pesticides in soil and water. Madison: Soil Science Society of America, 1974. p.38-66.

YAMANE, V.K.; GREEN, R.E. Adsorption of ametryne and atrazine on na oxisoil, montmorillonite and charcoal in relation to $\mathrm{pH}$ and solubility effects. Soil Science Society of America Proceedings, v.36, p.58-64, 1972. 
APÊNDICES 
APÊNDICE 1. Desprendimento percentual de ${ }^{14} \mathrm{CO}_{2}$ do herbicida diuron nos dias 1,7 , $14,21,28,35,42,49,56,63$ e 120 após a aplicação nos solos Terra Roxa Estruturada e Latossolo Vermelho Amarelo tratados com 0; 100 e $200 \mathrm{~m}^{3} \mathrm{ha}^{-1}$ de vinhaça.

\begin{tabular}{|c|c|c|c|c|c|c|}
\hline \multirow{3}{*}{$\begin{array}{l}\text { Períodos de } \\
\text { avaliação }\end{array}$} & \multicolumn{6}{|c|}{ Desprendimento de ${ }^{14} \mathrm{CO}_{2}(\%)$} \\
\hline & \multicolumn{3}{|c|}{ Terra Roxa Estruturada } & \multicolumn{3}{|c|}{ Latossolo Vermelho Amarelo } \\
\hline & \multicolumn{6}{|c|}{ Dose de vinhaça $\left(\mathrm{m}^{3} \mathrm{ha}^{-1}\right)$} \\
\hline \multirow{4}{*}{ Dia 1} & 0 & 100 & 200 & 0 & 100 & 200 \\
\hline & 0,0673 & 0,0840 & 0,1036 & 0,0892 & 0,0730 & 0,0601 \\
\hline & 0,0453 & 0,0966 & 0,0872 & 0,0943 & 0,0717 & 0,0639 \\
\hline & 0,0601 & 0,0930 & 0,0952 & 0,0933 & 0,0672 & 0,0716 \\
\hline \multirow[t]{3}{*}{ Dia 7} & 0,8294 & 1,1385 & 1,2318 & 0,2409 & 0,2301 & 0,1854 \\
\hline & 0,8809 & 1,2600 & 1,1765 & 0,2161 & 0,2162 & 0,1759 \\
\hline & 0,8998 & 1,1205 & 1,1152 & 0,2119 & 0,2243 & 0,2043 \\
\hline \multirow[t]{3}{*}{ Dia 14} & 1,6540 & 3,1003 & 3,9553 & 0,4297 & 0,4462 & 0,3589 \\
\hline & 1,6280 & 3,7264 & 3,6169 & 0,4479 & 0,3863 & 0,4097 \\
\hline & 1,6991 & 3,1791 & 3,9749 & 0,4285 & 0,4694 & 0,5010 \\
\hline \multirow[t]{3}{*}{ Dia 21} & 2,0183 & 3,1551 & 3,7215 & 0,2862 & 0,3334 & 0,3102 \\
\hline & 1,8182 & 4,6615 & 4,1825 & 0,3109 & 0,2891 & 0,3770 \\
\hline & 1,9121 & 3,2532 & 2,9370 & 0,2844 & 0,3500 & 0,4328 \\
\hline \multirow[t]{3}{*}{ Dia 28} & 1,6380 & 2,2089 & 2,9420 & 0,2510 & 0,2895 & 0,2910 \\
\hline & 1,9783 & 3,4533 & 3,5226 & 0,2740 & 0,2758 & 0,3329 \\
\hline & 1,6726 & 2,1056 & 2,2591 & 0,2577 & 0,3140 & 0,3766 \\
\hline \multirow[t]{3}{*}{ Dia 35} & 1,2571 & 1,7726 & 3,1412 & 0,2456 & 0,2804 & 0,3048 \\
\hline & 1,6698 & 2,5753 & 3,5137 & 0,2537 & 0,2700 & 0,3544 \\
\hline & 1,3081 & 1,5484 & 2,4442 & 0,2481 & 0,3116 & 0,3619 \\
\hline \multirow[t]{3}{*}{ Dia 42} & 0,9995 & 1,6303 & 4,1122 & 0,2496 & 0,2696 & 0,3086 \\
\hline & 1,2926 & 2,1843 & 4,2559 & 0,2552 & 0,2612 & 0,3684 \\
\hline & 0,8642 & 1,3418 & 3,1829 & 0,2485 & 0,2796 & 0,3550 \\
\hline \multirow[t]{3}{*}{ Dia 49} & 0,7859 & 1,8122 & 5,6299 & 0,2389 & 0,2410 & 0,3068 \\
\hline & 1,1051 & 2,3830 & 5,7568 & 0,2667 & 0,2497 & 0,3578 \\
\hline & 0,8171 & 1,5559 & 4,5531 & 0,2570 & 0,2748 & 0,3655 \\
\hline \multirow[t]{3}{*}{ Dia 56} & 0,7106 & 1,8369 & 5,8764 & 0,2068 & 0,2105 & 0,2582 \\
\hline & 0,8502 & 2,3556 & 6,0901 & 0,2135 & 0,2035 & 0,2882 \\
\hline & 0,7184 & 1,5432 & 4,9539 & 0,2002 & 0,2292 & 0,2748 \\
\hline \multirow[t]{3}{*}{ Dia 63} & 0,6976 & 1,7265 & 5,3749 & 0,1738 & 0,1800 & 0,2131 \\
\hline & 0,8312 & 2,4488 & 5,4022 & 0,1761 & 0,1808 & 0,2394 \\
\hline & 0,6659 & 1,5082 & 4,7337 & 0,1794 & 0,1970 & 0,2221 \\
\hline \multirow[t]{3}{*}{ Dia 120} & 3,9518 & 16,2233 & 27,2833 & 1,0978 & 1,0223 & 1,2012 \\
\hline & 4,4465 & 18,9154 & 23,2849 & 1,0961 & 1,1440 & 1,3450 \\
\hline & 3,7329 & 15,6052 & 24,7936 & 1,0817 & 1,1642 & 1,3077 \\
\hline
\end{tabular}


APÊNDICE 2. Média $(*)$, desvio padrão $(* *)$ e coeficiente de variação $(\%)(* * *)$ dos resultados de desprendimento de ${ }^{14} \mathrm{CO}_{2}(\%)$ do herbicida diuron nos dias $1,7,14,21,28,35,42,49,56,63$ e 120 após a aplicação nos solos TR e LV tratados com $0 ; 100$ e $200 \mathrm{~m}^{3} \mathrm{ha}^{-1}$ de vinhaca.

\begin{tabular}{|c|c|c|c|c|c|c|}
\hline \multirow{3}{*}{$\begin{array}{l}\text { Períodos de } \\
\text { avaliação }\end{array}$} & \multicolumn{6}{|c|}{ Desprendimento de ${ }^{14} \mathrm{CO}_{2}(\%)$} \\
\hline & \multicolumn{3}{|c|}{ Terra Roxa Estruturada } & \multicolumn{3}{|c|}{ Latossolo Vermelho Amarelo } \\
\hline & \multicolumn{6}{|c|}{ Dose de vinhaça $\left(\mathrm{m}^{3} \mathrm{ha}^{-1}\right)$} \\
\hline \multirow{4}{*}{ Dia 1} & $\mathbf{0}$ & 100 & 200 & 0 & 100 & 200 \\
\hline & $0,0575^{*}$ & 0,0912 & 0,0953 & 0,0922 & 0,0706 & 0,0652 \\
\hline & $0,0112 * *$ & 0,0064 & 0,008 & 0,0027 & 0,003 & 0,0058 \\
\hline & $19,4782 * * *$ & 7,0175 & 8,3945 & 2,9289 & 4,3089 & 8,9864 \\
\hline \multirow[t]{3}{*}{ Dia 7} & 0,8700 & 1,173 & 1,1745 & 0,2246 & 0,2235 & 0,1885 \\
\hline & 0,0364 & 0,0758 & 0,0583 & 0,0140 & 0,0069 & 0,0144 \\
\hline & 4,1879 & 6,4688 & 4,9660 & 6,2737 & 3,1233 & 7,6681 \\
\hline \multirow[t]{3}{*}{ Dia 14} & 1,6603 & 3,3352 & 3,8490 & 0,4353 & 0,4339 & 0,4232 \\
\hline & 0,0359 & 0,3410 & 0,2012 & 0,0108 & 0,0428 & 0,0720 \\
\hline & 2,16 & 10,2245 & 5,2291 & 2,4969 & 9,8808 & 17,0145 \\
\hline \multirow{3}{*}{ Dia 21} & 1,9162 & 3,6899 & 3,6136 & 0,2938 & 0,3241 & 0,3733 \\
\hline & 0,1001 & 0,8428 & 0,6297 & 0,0148 & 0,0314 & 0,0428 \\
\hline & 5,2245 & 22,8413 & 17,4258 & 5,0394 & 9,7118 & 16,4416 \\
\hline \multirow[t]{3}{*}{ Dia 28} & 1,7629 & 2,5892 & 2,9079 & 0,2607 & 0,2931 & 0,3335 \\
\hline & 0,1872 & 0,7501 & 0,6324 & 0,0119 & 0,0193 & 0,0428 \\
\hline & 10,6232 & 28,9703 & 21,7490 & 4,5704 & 6,6027 & 12,8345 \\
\hline \multirow[t]{3}{*}{ Dia 35} & 1,4116 & 1,9654 & 3,0330 & 0,2511 & 0,2873 & 0,3403 \\
\hline & 0,2249 & 0,5399 & 0,5428 & 0,0035 & 0,0216 & 0,0310 \\
\hline & 15,9385 & 27,4710 & 17,8993 & 1,6648 & 7,5345 & 9,1163 \\
\hline \multirow[t]{3}{*}{ Dia 42} & 1,0521 & 1,7188 & 3,8503 & 0,2511 & 0,2701 & 0,344 \\
\hline & 0,2189 & 0,4281 & 0,5824 & 0,0141 & 0,0092 & 0,0313 \\
\hline & 20,8145 & 24,9107 & 15,1275 & 5,5468 & 3,4100 & 9,1223 \\
\hline \multirow[t]{3}{*}{ Dia 49} & 0,9027 & 1,9170 & 5,3132 & 0,2542 & 0,2551 & 0,3433 \\
\hline & 0,1759 & 0,4113 & 0,6613 & 0,0141 & 0,0175 & 0,0319 \\
\hline & 19,4944 & 21,5157 & 12,4476 & 5,5468 & 6,8780 & 9,2906 \\
\hline \multirow[t]{3}{*}{ Dia 56} & 0,7597 & 1,9119 & 5,6431 & 0,2068 & 0,2144 & 0,2737 \\
\hline & 0,0784 & 0,4113 & 0,6071 & 0,0066 & 0,0132 & 0,0150 \\
\hline & 10,3251 & 21,5157 & 10,7598 & 3,2151 & 3,1970 & 5,9441 \\
\hline \multirow[t]{3}{*}{ Dia 63} & 0,7315 & 1,8945 & 5,1702 & 0,1764 & 0,1859 & 0,2248 \\
\hline & 0,0877 & 0,4922 & 0,3783 & 0,0028 & 0,0095 & 0,0133 \\
\hline & 11,9918 & 25,9852 & 7,3169 & 1,5954 & 5,1590 & 5,9441 \\
\hline \multirow[t]{3}{*}{ Dia 120} & 4,0437 & 16,9148 & 25,1206 & 1,0918 & 1,1101 & 1,2846 \\
\hline & 0,3655 & 1,7603 & 2,0191 & 0,0088 & 0,0767 & 0,0746 \\
\hline & 9,0405 & 10,4071 & 8,0378 & 0,8101 & 6,9144 & 5,8089 \\
\hline
\end{tabular}


APÊNDICE 3. Desprendimento percentual de ${ }^{14} \mathrm{CO}_{2}$ do herbicida ametrina nos dias 1 , $7,14,21,28,35,42,49,56,63$ e 120 após a aplicação nos solos Terra Roxa Estruturada e Latossolo Vermelho Amarelo tratados com 0;100 e $200 \mathrm{~m}^{3} \mathrm{ha}^{-1}$ de vinhaca.

\begin{tabular}{|c|c|c|c|c|c|c|}
\hline \multirow{3}{*}{$\begin{array}{l}\text { Periodos de } \\
\text { avaliação }\end{array}$} & \multicolumn{6}{|c|}{ Desprendimento de ${ }^{14} \mathrm{CO}_{2}(\%)$} \\
\hline & \multicolumn{3}{|c|}{ Terra Roxa Estruturada } & \multicolumn{3}{|c|}{ Latossolo Vermelho Amarelo } \\
\hline & & & Dose de v & $\left(\mathrm{m}^{3} \mathrm{ha}^{-1}\right)$ & & \\
\hline \multirow{4}{*}{ Dia 1} & 0 & 100 & 200 & 0 & 100 & 200 \\
\hline & 0,0014 & 0,0085 & 0,0053 & 0,0000 & 0,0143 & 0,0000 \\
\hline & 0,0000 & 0,0074 & 0,0085 & 0,0084 & 0,0044 & 0,0032 \\
\hline & 0,0000 & 0,0063 & 0,0000 & 0,0076 & 0,0000 & 0,0006 \\
\hline \multirow[t]{3}{*}{ Dia 7} & 0,0970 & 0,0725 & 0,0479 & 0,0297 & 0,0489 & 0,0283 \\
\hline & 0,0492 & 0,0734 & 0,0784 & 0,0345 & 0,0618 & 0,0111 \\
\hline & 0,0538 & 0,0744 & 0,0666 & 0,0449 & 0,0555 & 0,0076 \\
\hline \multirow[t]{3}{*}{ Dia 14} & 0,0908 & 0,1598 & 0,2650 & 0,0263 & 0,0183 & 0,0037 \\
\hline & 0,0833 & 0,1422 & 0,2959 & 0,0238 & 0,0098 & 0,0037 \\
\hline & 0,0797 & 0,1247 & 0,2265 & 0,0185 & 0,0145 & 0,0063 \\
\hline \multirow[t]{3}{*}{ Dia 21} & 0,1985 & 0,2897 & 0,5417 & 0,0222 & 0,0401 & 0,0102 \\
\hline & 0,1083 & 0,2598 & 0,6356 & 0,0134 & 0,0362 & 0,0079 \\
\hline & 0,1093 & 0,2299 & 0,4805 & 0,0182 & 0,0382 & 0,0051 \\
\hline \multirow[t]{3}{*}{ Dia 28} & 0,1566 & 0,4310 & 0,8221 & 0,0074 & 0,0733 & 0,0117 \\
\hline & 0,1427 & 0,3799 & 0,9438 & 0,0084 & 0,0480 & 0,0077 \\
\hline & 0,1705 & 0,3288 & 0,7672 & 0,0055 & 0,0665 & 0,0016 \\
\hline \multirow[t]{3}{*}{ Dia 35} & 0,2535 & 0,6321 & 1,0920 & 0,0256 & 0,1101 & 0,0297 \\
\hline & 0,2158 & 0,6321 & 1,1322 & 0,0298 & 0,0887 & 0,0237 \\
\hline & 0,2912 & 0,4699 & 1,9664 & 0,0320 & 0,0994 & 0,0207 \\
\hline \multirow[t]{3}{*}{ Dia 42} & 0,4736 & 0,7580 & 1,1325 & 0,0303 & 0,1687 & 0,0353 \\
\hline & 0,2837 & 0,6676 & 1,0842 & 0,0291 & 0,1552 & 0,0291 \\
\hline & 0,4576 & 0,5420 & 0,9802 & 0,0255 & 0,1711 & 0,0163 \\
\hline \multirow[t]{3}{*}{ Dia 49} & 0,6889 & 1,0326 & 1,1847 & 0,0225 & 0,3319 & 0,0675 \\
\hline & 0,3778 & 0,8033 & 1,2314 & 0,0223 & 0,3489 & 0,0564 \\
\hline & 0,6894 & 0,6424 & 0,9616 & 0,0256 & 0,3402 & 0,0617 \\
\hline \multirow[t]{3}{*}{ Dia 56} & 1,1239 & 0,9650 & 1,2247 & 0,0144 & 0,5740 & 0,1848 \\
\hline & 1,0944 & 0,7457 & 0,8754 & 0,0203 & 0,5714 & 0,1065 \\
\hline & 1,2061 & 1,1742 & 0,9560 & 0,0159 & 0,5727 & 0,1457 \\
\hline \multirow[t]{3}{*}{ Dia 63} & 2,5830 & 1,3298 & 1,2148 & 0,0246 & 0,7684 & 0,2901 \\
\hline & 1,7115 & 1,0699 & 1,5146 & 0,0169 & 0,7360 & 0,1717 \\
\hline & 0,6346 & 0,8100 & 0,8368 & 0,0269 & 0,7522 & 0,2309 \\
\hline \multirow[t]{3}{*}{ Dia 120} & 20,4355 & 24,8058 & 17,4529 & 0,2212 & 4,4412 & 1,5896 \\
\hline & 19,7102 & 21,0708 & 14,4339 & 0,1392 & 3,9216 & 1,4358 \\
\hline & 19,8801 & 22,7710 & 15,3508 & 0,2899 & 5,7559 & 1,4137 \\
\hline
\end{tabular}


APÊNDICE 4. Média $(*)$, desvio padrão $(* *)$ e coeficiente de variação $(\%)(* * *)$ dos resultados de desprendimento de ${ }^{14} \mathrm{CO}_{2}(\%)$ do herbicida ametrina nos dias $1,7,14,21,28,35,42,49,56,63$ e 120 após a aplicação nos solos TR e LV tratados com $0 ; 100$ e $200 \mathrm{~m}^{3} \mathrm{ha}^{-1}$ de vinhaça.

\begin{tabular}{|c|c|c|c|c|c|c|}
\hline \multirow{3}{*}{$\begin{array}{l}\text { Períodos de } \\
\text { avaliação }\end{array}$} & \multicolumn{6}{|c|}{ Desprendimento $\mathrm{de}^{14} \mathrm{CO}_{2}(\%)$} \\
\hline & \multirow{2}{*}{\multicolumn{3}{|c|}{$\frac{\text { Terra Roxa Estruturada }}{\text { Dose de } v}$}} & \multicolumn{3}{|c|}{ Latossolo Vermelho Amarelo } \\
\hline & & & & $a\left(m^{3} h a^{-1}\right)$ & & \\
\hline \multirow{4}{*}{ Dia 1} & 0 & 100 & 200 & 0 & 100 & 200 \\
\hline & $0,0004^{*}$ & 0,0074 & 0,0046 & 0,0053 & 0,0062 & 0,0012 \\
\hline & $0,0008 * *$ & 0,0011 & 0,0042 & 0,0046 & 0,0073 & 0,0017 \\
\hline & $173,0050^{* * *}$ & 14,8658 & 93,3264 & 86,9266 & 117,4994 & 134,2879 \\
\hline \multirow[t]{3}{*}{ Dia 7} & 0,0866 & 0,0734 & 0,0643 & 0,0363 & 0,0554 & 0,0156 \\
\hline & 0,0091 & 0,0009 & 0,0153 & 0,0077 & 0,0064 & 0,01107 \\
\hline & 10,5324 & 1,2942 & 23,9184 & 21,3657 & 11,6436 & 71,3589 \\
\hline \multirow[t]{3}{*}{ Dia 14} & 0,0980 & 0,1422 & 0,2624 & 0,0228 & 0,0142 & 0,0156 \\
\hline & 0,0833 & 0,0175 & 0,0347 & 0,0039 & 0,0042 & 0,0110 \\
\hline & 6,6938 & 12,3066 & 13,2471 & 17,4178 & 29,9854 & 33,0269 \\
\hline \multirow[t]{3}{*}{ Dia 21} & 0,1387 & 0,2747 & 0,5526 & 0,0179 & 0,0381 & 0,0077 \\
\hline & 0,0517 & 0,0211 & 0,0781 & 0,0044 & 0,0019 & 0,0025 \\
\hline & 37,3401 & 7,6951 & 14,1372 & 24,5690 & 5,1097 & 33,0269 \\
\hline \multirow[t]{3}{*}{ Dia 28} & 0,1566 & 0,3799 & 0,8443 & 0,0071 & 0,0626 & 0,007 \\
\hline & 0,0139 & 0,0511 & 0,0903 & 0,0014 & 0,0130 & 0,0050 \\
\hline & 8,8761 & 13,4509 & 10,7040 & 20,7477 & 20,9155 & 72,6607 \\
\hline \multirow[t]{3}{*}{ Dia 35} & 0,2323 & 0,5780 & 1,3968 & 0,0291 & 0,0994 & 0,0247 \\
\hline & 0,0299 & 0,0936 & 0,4936 & 0,0032 & 0,0107 & 0,0045 \\
\hline & 12,8730 & 16,2008 & 35,3390 & 11,1613 & 10,7645 & 18,5529 \\
\hline \multirow[t]{3}{*}{ Dia 42} & 0,4049 & 0,6558 & 1,0656 & 0,0283 & 0,165 & 0,0269 \\
\hline & 0,1053 & 0,1084 & 0,0778 & 0,0024 & 0,0085 & 0,0096 \\
\hline & 26,0081 & 16,5394 & 7,3035 & 8,8268 & 5,1948 & 36,0192 \\
\hline \multirow[t]{3}{*}{ Dia 49} & 0,5853 & 0,8261 & 1,1259 & 0,0234 & 0,3403 & 0,0618 \\
\hline & 0,1797 & 0,1960 & 0,1441 & 0,0018 & 0,0085 & 0,0055 \\
\hline & 30,7086 & 23,7376 & 12,8067 & 7,8844 & 2,4977 & 8,9739 \\
\hline \multirow[t]{3}{*}{ Dia 56} & 1,1414 & 0,9616 & 1,0187 & 0,0168 & 0,5727 & 0,1456 \\
\hline & 0,0578 & 0,2142 & 0,1828 & 0,0030 & 0,0013 & 0,0391 \\
\hline & 5,0710 & 22,2818 & 17,9539 & 18,1807 & 0,2269 & 26,8764 \\
\hline \multirow[t]{3}{*}{ Dia 63} & 1,643 & 1,0699 & 1,1887 & 0,0228 & 0,7522 & 0,2309 \\
\hline & 0,9760 & 0,2599 & 0,3396 & 0,0052 & 0,0162 & 0,0592 \\
\hline & 59,4068 & 24,2919 & 28,5727 & 22,9705 & 2,1536 & 25,6388 \\
\hline \multirow[t]{3}{*}{ Dia 120} & 20,0080 & 22,8825 & 15,7292 & 0,2167 & 4,7062 & 1,4863 \\
\hline & 0,3793 & 1,8699 & 1,5544 & 0,0754 & 0,9454 & 0,0894 \\
\hline & 1,8958 & 8,1721 & 9,8824 & 34,8059 & 20,0889 & 6,0152 \\
\hline
\end{tabular}


APÊNDICE 5. Valores obtidos para a concentração de equilibrio e adsorção, nas cinco concentrações estudadas, do herbicida diuron em solo da classe Terra Roxa Estruturada tratada com as doses de 0, 100 e $200 \mathrm{~m}^{3} \mathrm{ha}^{-1}$.

\begin{tabular}{|c|c|c|c|c|c|c|}
\hline \multirow[b]{4}{*}{ Concentração } & \multicolumn{6}{|c|}{ 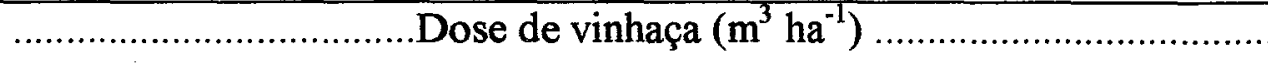 } \\
\hline & \multicolumn{2}{|c|}{0} & \multicolumn{2}{|c|}{100} & \multicolumn{2}{|c|}{200} \\
\hline & $\begin{array}{c}\mathrm{C}_{\mathrm{e}} \\
\mu \mathrm{g} \mathrm{mL}^{-1}\end{array}$ & $\begin{array}{c}\mathrm{A} \\
\mu \mathrm{g} \mathrm{g}^{-1}\end{array}$ & $\begin{array}{c}\mathrm{C}_{\mathrm{e}} \\
\mu \mathrm{g} \mathrm{mL}^{-1}\end{array}$ & $\begin{array}{c}\mathrm{A} \\
\mu \mathrm{g} \mathrm{g}^{-1}\end{array}$ & $\begin{array}{c}\mathrm{C}_{\mathrm{e}} \\
\mu \mathrm{g} \mathrm{mL}^{-1}\end{array}$ & $\begin{array}{c}\mathrm{A} \\
\mu \mathrm{g} \mathrm{g}^{-1}\end{array}$ \\
\hline & & & & & & \\
\hline \multirow[t]{3}{*}{1} & 1,04 & 2,44 & 1,07 & 2,23 & 1,05 & 2,36 \\
\hline & 1,06 & 2,30 & 1,07 & 2,16 & 1,07 & 2,18 \\
\hline & 1,07 & 2,22 & 1,07 & 2,16 & 1,07 & 2,23 \\
\hline \multirow[t]{3}{*}{2} & 2,05 & 4,66 & 2,17 & 3,42 & 2,08 & 4,32 \\
\hline & 2,08 & 4,35 & 2,18 & 3,38 & 2,09 & 4,19 \\
\hline & 2,09 & 4,25 & 2,15 & 3,67 & 2,08 & 4,36 \\
\hline \multirow[t]{3}{*}{3} & 4,15 & 5,55 & 4,23 & 4,79 & 4,06 & 6,45 \\
\hline & 4,10 & 6,03 & 4,16 & 5,46 & 4,09 & 6,17 \\
\hline & 4,13 & 5,79 & 4,14 & 5,62 & 4,12 & 5,82 \\
\hline \multirow[t]{3}{*}{4} & 5,72 & 8,64 & 5,87 & 7,14 & 5,69 & 8,98 \\
\hline & 5,85 & 7,34 & 5,92 & 6,68 & 5,72 & 8,65 \\
\hline & 5,84 & 7,49 & 5,99 & 5,97 & 5,73 & 8,56 \\
\hline \multirow[t]{3}{*}{5} & 8,44 & 9,67 & 8,56 & 8,46 & 8,27 & 11,43 \\
\hline & 8,54 & 8,74 & 8,57 & 8,45 & 8,28 & 11,28 \\
\hline & 8,44 & 9,68 & 8,57 & 8,45 & 8,36 & 10,56 \\
\hline
\end{tabular}


APÊNDICE 6. Valores de média $\left({ }^{*}\right)$, desvio padrão $\left({ }^{* *}\right)$ e coeficiente de variação, em percentagem, $\left({ }^{* * *}\right)$ obtidos para a concentração de equilíbrio e adsorção, nas cinco concentrações estudadas, do herbicida diuron em solo da classe Terra Roxa Estruturada tratada com as doses de 0, $100 \mathrm{e}$ $200 \mathrm{~m}^{3} \mathrm{ha}^{-1}$.

\begin{tabular}{|c|c|c|c|c|c|c|}
\hline \multirow[b]{4}{*}{ Concentração } & \multicolumn{6}{|c|}{ 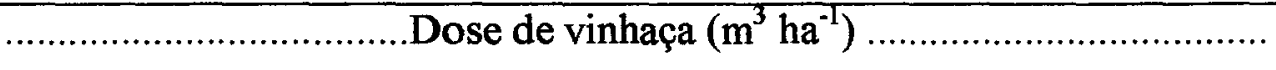 } \\
\hline & \multicolumn{2}{|c|}{0} & \multicolumn{2}{|c|}{100} & \multicolumn{2}{|c|}{200} \\
\hline & $\begin{array}{c}\mathrm{C}_{\mathrm{e}} \\
\mu \mathrm{g} \mathrm{mL}^{-1}\end{array}$ & $\begin{array}{c}\mathrm{A} \\
\mu \mathrm{g} \mathrm{g}^{-1}\end{array}$ & $\begin{array}{c}\mathrm{C}_{\mathrm{e}} \\
\mu \mathrm{g} \mathrm{mL} \mathrm{mL}^{-1}\end{array}$ & $\begin{array}{c}\mathrm{A} \\
\mu \mathrm{g} \mathrm{g}^{-1}\end{array}$ & $\begin{array}{c}\mathrm{C}_{\mathrm{e}} \\
\mu \mathrm{g} \mathrm{mL}^{-1}\end{array}$ & $\begin{array}{c}\mathrm{A} \\
\mu \mathrm{g} \mathrm{g}^{-1}\end{array}$ \\
\hline & & & & & & \\
\hline \multirow[t]{3}{*}{1} & $1,06^{*}$ & 2,32 & 1,07 & 2,18 & 1,06 & 2,25 \\
\hline & $0,015^{* *}$ & 0,111 & 0 & 0,040 & 0,011 & 0,092 \\
\hline & $1,44^{* * *}$ & 4,79 & 0 & 1,85 & 1,08 & 4,11 \\
\hline \multirow[t]{3}{*}{2} & 2,07 & 4,42 & 2,17 & 3,49 & 2,08 & 4,29 \\
\hline & 0,021 & 0,213 & 0,015 & 0,157 & 0 & 0,088 \\
\hline & 1,00 & 4,83 & 0,70 & 4,51 & 0 & 2,07 \\
\hline \multirow[t]{3}{*}{3} & 4,12 & 5,79 & 4,15 & 5,29 & 4,09 & 6,15 \\
\hline & 0,025 & 0,24 & 0,066 & 0,440 & 0,03 & 0,32 \\
\hline & 0,61 & 4,15 & 1,60 & 8,32 & 0,73 & 5,51 \\
\hline \multirow[t]{3}{*}{4} & 5,80 & 7,82 & 5,92 & 6,60 & 5,71 & 8,73 \\
\hline & 0,072 & 0,711 & 0,060 & 0,589 & 0,021 & 0,001 \\
\hline & 1,24 & 9,09 & 1,10 & 8,93 & 0,36 & 2,53 \\
\hline \multirow[t]{3}{*}{5} & 8,47 & 9,36 & 8,57 & 8,45 & 8,30 & 11,09 \\
\hline & 0,057 & 0,539 & 0,005 & 0,005 & 0,049 & 0,465 \\
\hline & 0,68 & 5,76 & 0,07 & 0,07 & 0,59 & 4,19 \\
\hline
\end{tabular}


APÊNDICE 7. Valores obtidos para a concentração de equilíbrio e adsorção, nas cinco concentrações estudadas, do herbicida diuron em solo da classe Latossolo Vermelho Amarelo tratado com as doses de 0, 100 e $200 \mathrm{~m}^{3}$ $\mathrm{ha}^{-1}$.

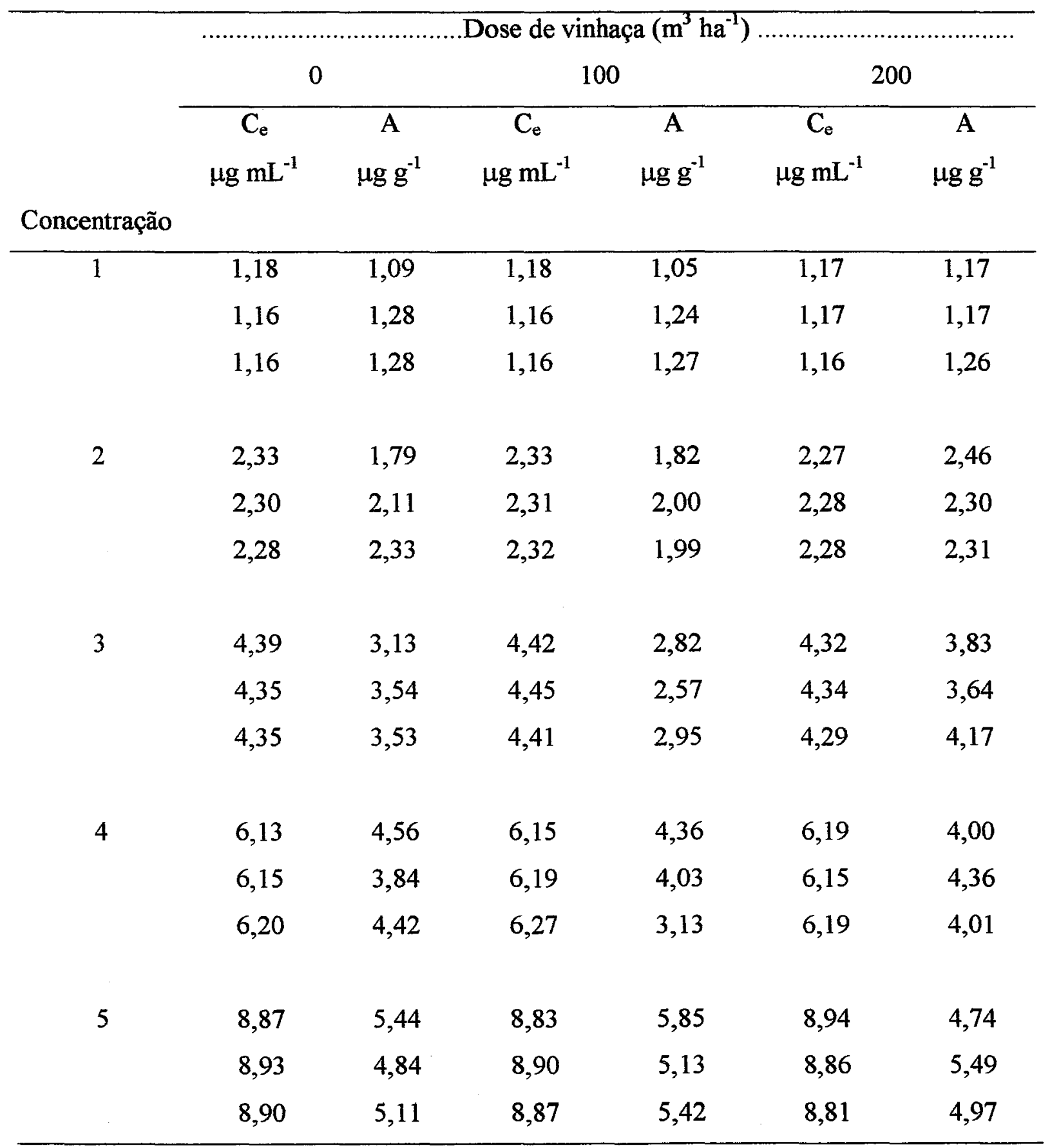


APÊNDICE 8. Valores de média $\left({ }^{*}\right)$, desvio padrão $\left({ }^{* *}\right)$ e coeficiente de variação, em percentagem, $\left({ }^{* * *}\right)$ obtidos para a concentração de equilibrio e adsorção, nas cinco concentrações estudadas, do herbicida diuron em solo da classe Latossolo Vermelho Amarelo tratado com as doses de 0 , 100 e $200 \mathrm{~m}^{3} \mathrm{ha}^{-1}$.

.Dose de vinhaça $\left(\mathrm{m}^{3} \mathrm{ha}^{-1}\right)$

\begin{tabular}{llllll} 
& & \multicolumn{2}{c}{100} & & \multicolumn{2}{c}{200} \\
\hline $\mathrm{C}_{\mathrm{e}}$ & $\mathrm{A}$ & $\mathrm{C}_{\mathrm{e}}$ & $\mathrm{A}$ & $\mathrm{C}_{\mathrm{e}}$ & $\mathrm{A}$
\end{tabular}

$\mu \mathrm{g} \mathrm{mL}^{-1} \quad \mu \mathrm{g} \mathrm{g}^{-1} \quad \mu \mathrm{g} \mathrm{mL}^{-1} \quad \mu \mathrm{g} \mathrm{g}^{-1} \quad \mu \mathrm{g} \mathrm{mL}^{-1} \quad \mu \mathrm{g} \mathrm{g}^{-1}$

Concentração

\begin{tabular}{|c|c|c|c|c|c|c|}
\hline \multirow[t]{3}{*}{1} & $1,17^{*}$ & 1,27 & 1,17 & 1,18 & 1,17 & 1,20 \\
\hline & $0,011^{* *}$ & 0,109 & 0,011 & 0,119 & 0,005 & 0,051 \\
\hline & $0,98 * * *$ & 9,01 & 0,98 & 10,05 & 0,49 & 4,33 \\
\hline \multirow[t]{3}{*}{2} & 2,30 & 2,08 & 2,32 & 1,94 & 2,28 & 2,35 \\
\hline & 0,025 & 0,271 & 0,01 & 0,101 & 0,005 & 0,089 \\
\hline & 1,09 & 13,07 & 0,43 & 5,22 & 0,25 & 3,80 \\
\hline \multirow[t]{3}{*}{3} & 4,36 & 3,40 & 4,43 & 2,78 & 4,31 & 3,88 \\
\hline & 0,023 & 0,233 & 0,021 & 0,193 & 0,025 & 0,268 \\
\hline & 0,53 & 6,87 & 0,47 & 0,069 & 0,58 & 6,92 \\
\hline \multirow[t]{3}{*}{4} & 6,16 & 4,27 & 6,20 & 3,84 & 6,17 & 4,12 \\
\hline & 0,036 & 0,381 & 0,061 & 0,636 & 0,023 & 0,205 \\
\hline & 0,58 & 8,93 & 0,98 & 16,57 & 0,37 & 4,97 \\
\hline \multirow[t]{3}{*}{5} & 8,90 & 5,13 & 8,86 & 5,47 & 8,87 & 5,07 \\
\hline & 0,030 & 0,300 & 0,035 & 0,362 & 0,065 & 0,384 \\
\hline & 0,33 & 5,85 & 0,39 & 6,62 & 0,73 & 7,58 \\
\hline
\end{tabular}


APÊNDICE 9. Valores obtidos para a concentração de equilíbrio e adsorção, nas cinco concentrações estudadas, do herbicida ametrina em solo da classe Terra Roxa Estruturada tratado com as doses de 0,100 e $200 \mathrm{~m}^{3} \mathrm{ha}^{-1}$.

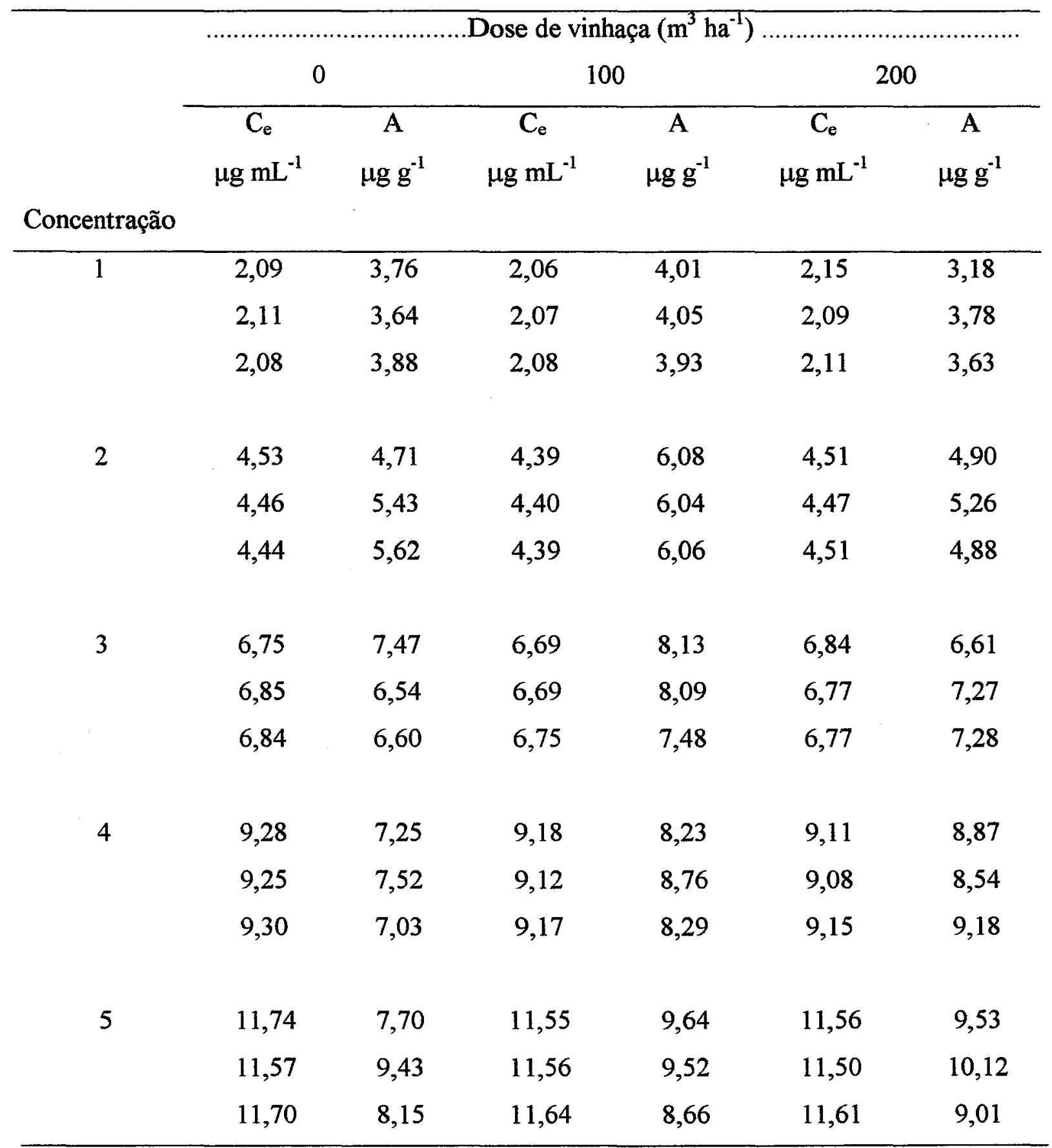


APÊNDICE 10. Valores de média $\left({ }^{*}\right)$, desvio padrão $\left({ }^{* *}\right)$ e coeficiente de variação, em percentagem, $\left({ }^{* * *}\right)$ obtidos para a concentração de equilíbrio e adsorção, nas cinco concentrações estudadas, do herbicida ametrina em solo da classe Terra Roxa Estruturada tratado com as doses de $0,100 \mathrm{e}$ $200 \mathrm{~m}^{3} \mathrm{ha}^{-1}$.

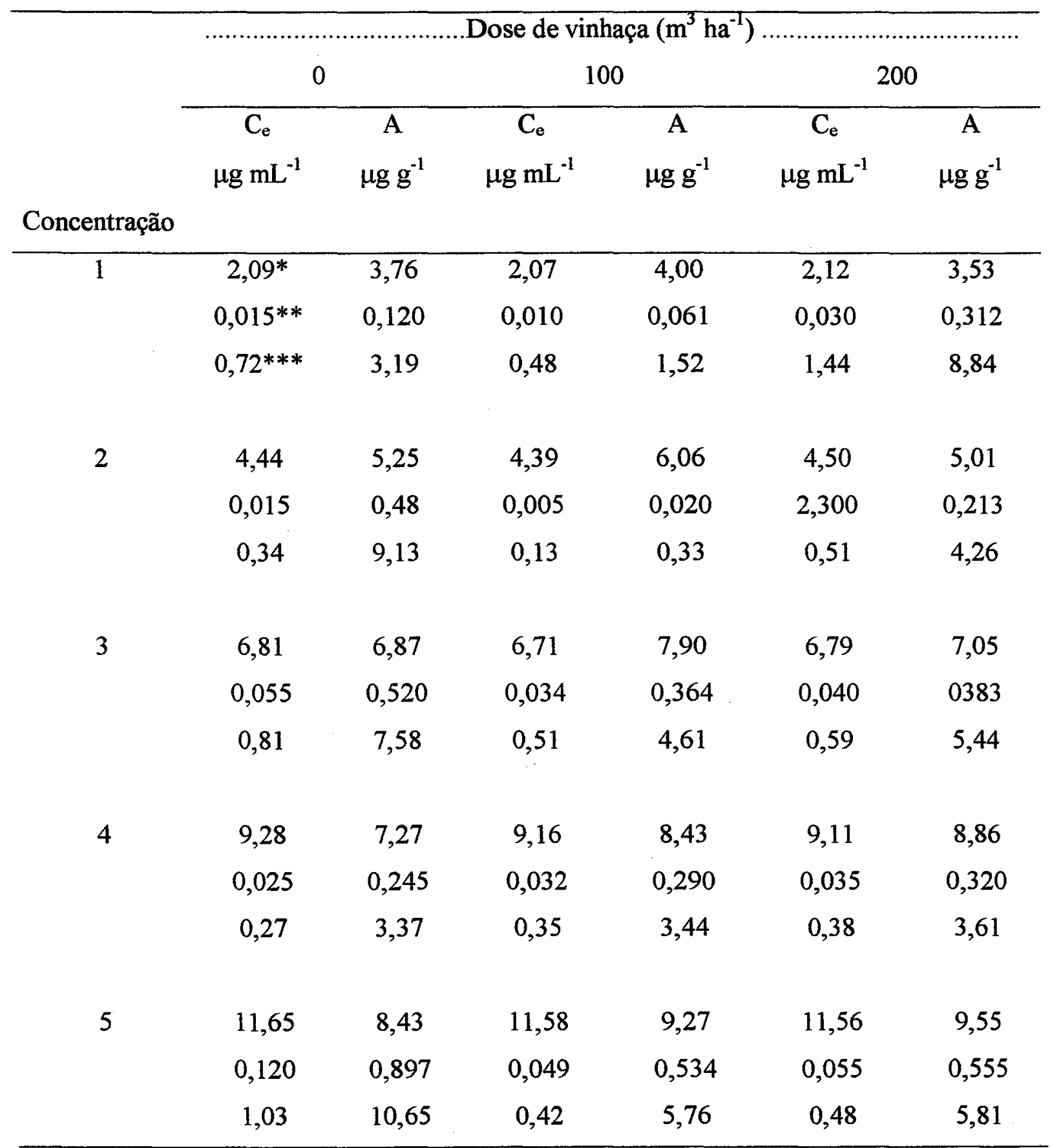


APÊNDICE 11. Valores obtidos para a concentração de equilíbrio e adsorção, nas cinco concentrações estudadas, do herbicida ametrina em solo da classe Latossolo Vermelho Amarelo tratado com as doses de 0, 100 e $200 \mathrm{~m}^{3}$ $\mathrm{ha}^{-1}$.

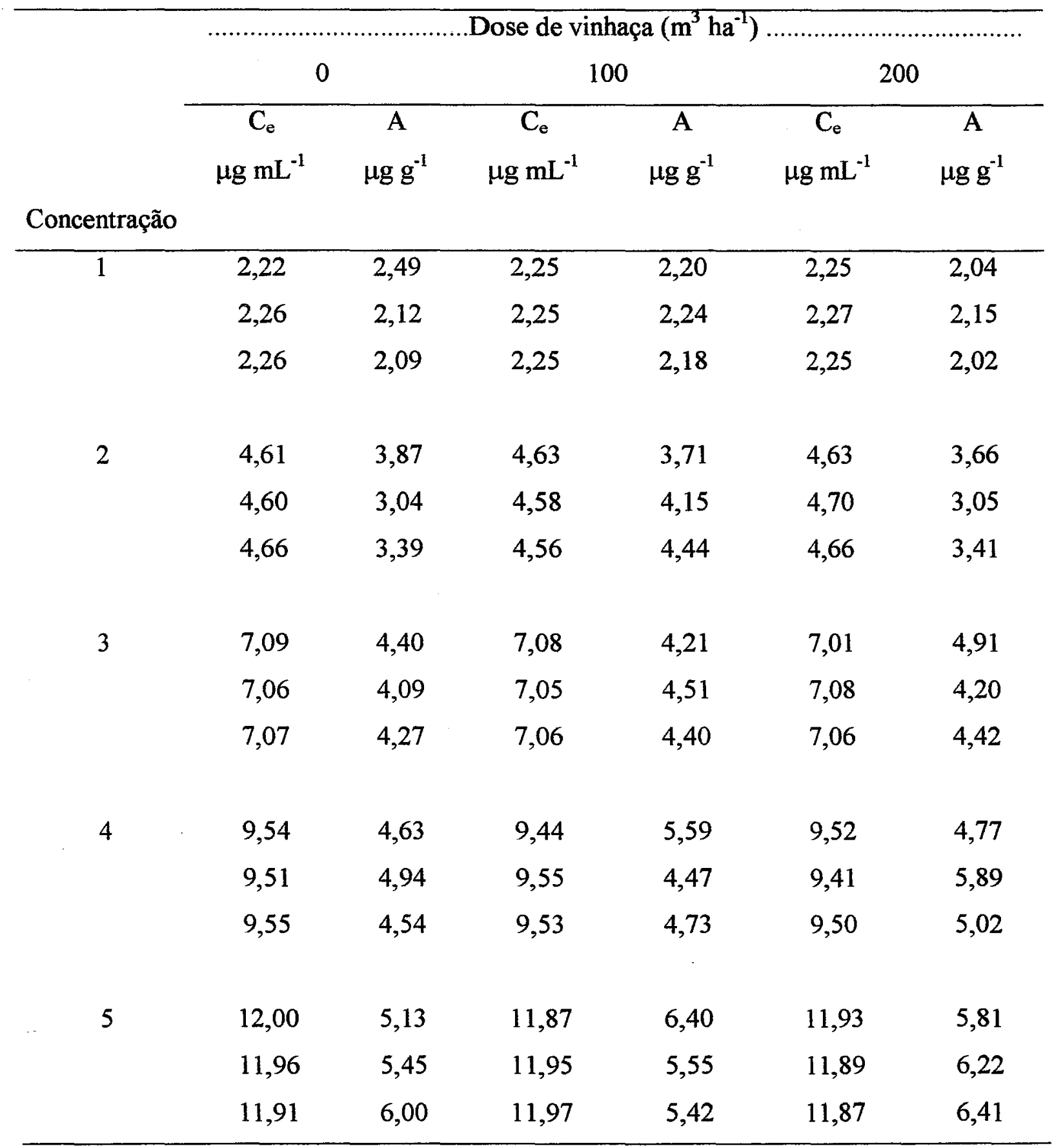


APÊNDICE 12. Valores de média $\left({ }^{*}\right)$, desvio padrão $\left({ }^{* *}\right)$ e coeficiente de variação, em percentagem, $\left({ }^{* * *}\right)$ obtidos para a concentração de equilíbrio e adsorção, nas cinco concentrações estudadas, do herbicida ametrina em solo da classe Latossolo Vermelho Amarelo tratado com as doses de 0 , 100 e $200 \mathrm{~m}^{3} \mathrm{ha}^{-1}$.

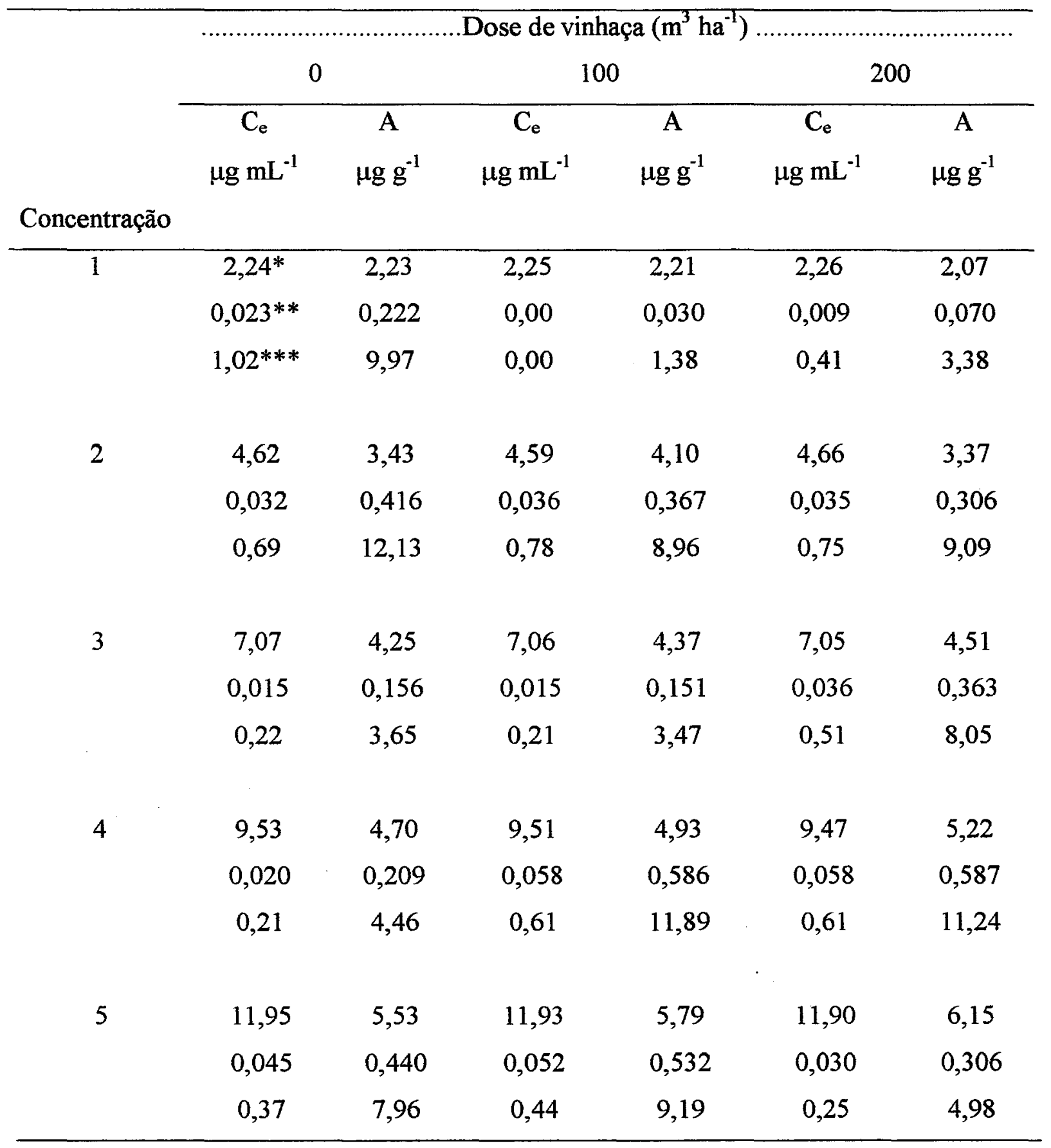


APÊNDICE 13. Análise de variância para ${ }^{14} \mathrm{CO}_{2}$ desprendido após 28 dias da aplicação dos herbicida diuron.

\begin{tabular}{ccccc}
\hline Fontes de variação & G.L. & S.Q. & Q.M. & F \\
\hline Solo & 1 & 312,1667 & 312,1667 & $398,97^{* *}$ \\
Dose de vinhaça & 2 & 26,0557 & 13,0278 & $16,65^{* *}$ \\
Solo x Dose & 2 & 27,0368 & 13,5184 & $17,28^{* *}$ \\
Resíduo & 12 & 9,3892 & 0,7824 & \\
\hline Total & 17 & 374,6485 & & \\
\hline
\end{tabular}

C.V. $=16,0180$

** Significativo ao nível de probabilidade de 0,01 . 
APÊNDICE 14. Análise de variância para $0^{14} \mathrm{CO}_{2}$ desprendido após 28 dias da aplicação dos herbicida ametrina.

\begin{tabular}{ccccc}
\hline Fontes de variação & G.L. & S.Q. & Q.M. & F \\
\hline Solo & 1 & 3,7355 & 3,7355 & $344,82^{* *}$ \\
Dose de vinhaça & 2 & 1,1536 & 0,5768 & $53,25^{* *}$ \\
Solo x Dose & 2 & 1,4668 & 0,7334 & $67,25^{* *}$ \\
Resíduo & 12 & 0,1300 & 0,0108 & \\
\hline Total & 17 & 6,4861 & & \\
\hline
\end{tabular}

C.V. $=18,66$

** Significativo ao nivel de probabilidade de 0,01 . 
APÊNDICE 15. Análise de variância para o ${ }^{14} \mathrm{CO}_{2}$ desprendido após 63 dias da aplicação dos herbicida diuron.

\begin{tabular}{ccccc}
\hline Fontes de variação & G.L. & S.Q. & Q.M. & F \\
\hline Solo & 1 & 1689,9360 & 1689,9360 & $298,17^{* *}$ \\
Dose de vinhaça & 2 & 439,0294 & 219,5147 & $38,73^{* *}$ \\
Solo x Dose & 2 & 404,8495 & 202,4247 & $35,72^{* *}$ \\
Resíduo & 12 & 68,0126 & 5,6677 & \\
\hline Total & 17 & 2601,8275 & & \\
\hline
\end{tabular}

C.V. $=19,31$

** Significativo ao nível de probabilidade de 0,01 . 
APÊNDICE 16. Análise de variância para $0^{14} \mathrm{CO}_{2}$ desprendido após 63 dias da aplicação dos herbicida ametrina.

\begin{tabular}{ccccc}
\hline Fontes de variação & G.L. & S.Q. & Q.M. & F \\
\hline Solo & 1 & 89,5122 & 89,5122 & $213,01^{* *}$ \\
Dose de vinhaça & 2 & 10,9233 & 5,4616 & $13,00^{* *}$ \\
Solo x Dose & 2 & 17,2332 & 8,6166 & $20,51^{* *}$ \\
Resíduo & 12 & 5,0426 & 0,4202 & \\
\hline Total & 17 & 122,7113 & &
\end{tabular}

C.V. $=19,17$

** Significativo ao nível de probabilidade de 0,01 . 
APÊNDICE 17. Análise de variância para o ${ }^{14} \mathrm{CO}_{2}$ desprendido após 120 dias da aplicação dos herbicida diuron.

\begin{tabular}{ccccc}
\hline Fontes de variação & G.L. & S.Q. & Q.M. & F \\
\hline Solo & 1 & 5074,2738 & 5074,2738 & $542,81^{* *}$ \\
Dose de vinhaça & 2 & 1536,3437 & 768,1718 & $82,17^{* *}$ \\
Solo x Dose & 2 & 1447,8286 & 723,9143 & $77,44^{* *}$ \\
Resíduo & 12 & 112,1782 & 9,3481 & \\
\hline Total & 17 & 8170,6244 & & \\
\hline C.V. $=14,8471$ & & &
\end{tabular}

** Significativo ao nível de probabilidade de 0,01 . 
APÊNDICE 18. Análise de variância para o ${ }^{14} \mathrm{CO}_{2}$ desprendido após 120 dias da aplicação dos herbicida ametrina.

\begin{tabular}{ccccc}
\hline Fontes de variação & G.L. & S.Q. & Q.M. & F \\
\hline Solo & 1 & 2158,2450 & 2158,2450 & $1005,39^{* *}$ \\
Dose de vinhaça & 2 & 103,7125 & 51,8562 & $24,16^{* *}$ \\
Solo x Dose & 2 & 10,7499 & 5,3749 & $2,50^{* *}$ \\
Resíduo & 12 & 25,7602 & 2,14668 & \\
\hline Total & 17 & 2298,4676 & & \\
\hline
\end{tabular}

C.V. $=10,29$

** Significativo ao nível de probabilidade de 0,01 . 